\title{
Exploration of Long-Chain Vitamin E Metabolites for the Discovery of a Highly Potent, Orally Effective, and Metabolically Stable 5-LOX Inhibitor that Limits Inflammation
}

Konstantin Neukirch," Khaled Alsabil," Chau-Phi Dinh, Rossella Bilancia, Martin Raasch, Alexia Ville, Ida Cerqua, Guillaume Viault, Dimitri Bréard, Simona Pace, Veronika Temml, Elena Brunner, Paul M. Jordan, Marta C. Marques, Konstantin Loeser, André Gollowitzer, Stephan Permann, Jana Gerstmeier, Stefan Lorkowski, Hermann Stuppner, Ulrike Garscha, Tiago Rodrigues, Gonçalo J. L. Bernardes, Daniela Schuster, Denis Séraphin, Pascal Richomme, Antonietta Rossi, Alexander S. Mosig, Fiorentina Roviezzo, Oliver Werz,* Jean-Jacques Helesbeux, * and Andreas Koeberle*

Cite This: J. Med. Chem. 2021, 64, 11496-11526

Read Online

ABSTRACT: Endogenous long-chain metabolites of vitamin E (LCMs) mediate immune functions by targeting 5-lipoxygenase (5LOX) and increasing the systemic concentrations of resolvin E3, a specialized proresolving lipid mediator. SAR studies on semisynthesized analogues highlight $\alpha$-amplexichromanol (27a), which allosterically inhibits 5-LOX, being considerably more potent than endogenous LCMs in human primary immune cells and blood. Other enzymes within lipid mediator biosynthesis were not substantially inhibited, except for microsomal prostaglandin $E_{2}$ synthase-1. Compound $27 \mathrm{a}$ is metabolized by sulfation and $\beta$ oxidation in human liver-on-chips and exhibits superior metabolic stability in mice over LCMs. Pharmacokinetic studies show

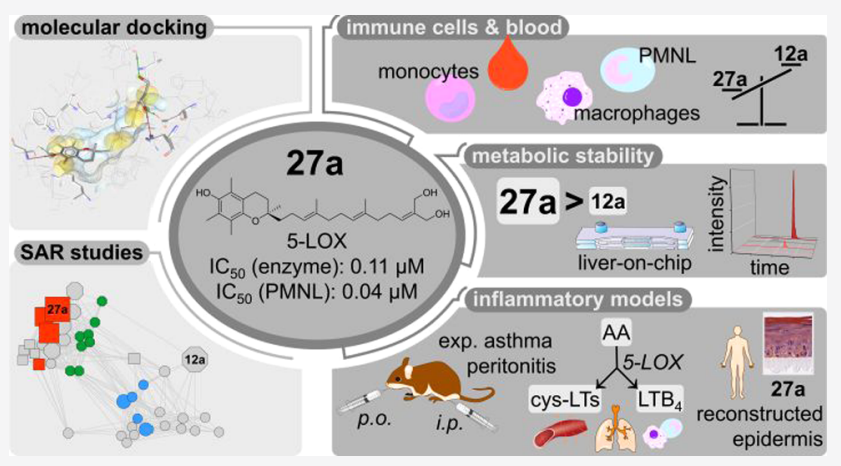
distribution of $27 \mathbf{a}$ from plasma to the inflamed peritoneal cavity and lung. In parallel, 5-LOX-derived leukotriene levels decrease, and the inflammatory reaction is suppressed in reconstructed human epidermis, murine peritonitis, and experimental asthma in mice. Our study highlights $27 \mathbf{a}$ as an orally active, LCM-inspired drug candidate that limits inflammation with superior potency and metabolic stability to the endogenous lead.

\section{INTRODUCTION}

Deficiency of vitamin E causes a dysfunctional immune response, degenerative diseases, and potentially atherosclerosis and Alzheimer's disease. ${ }^{1-5}$ The discovery that the vital antioxidant vitamin $\mathrm{E}$ mediates immune functions through endogenous long-chain metabolites (LCMs) recently revived research on this field. ${ }^{6-8}$ LCMs are produced from $\alpha$ tocopherol (1a) and other vitamin $E$ forms $(\mathbf{1 b}-\mathbf{d}, \mathbf{6 a}-\mathbf{d})$ by hepatic $\omega$-oxidation, yielding $\omega$-alcohols and then $\omega$ carboxylic acids, which are excreted via bile and feces, shortened by successive $\beta$-oxidations, or conjugated with sulfate or glucoronate for urinary elimination. ${ }^{7,8}$ The LCMs $\alpha$ $\mathrm{T}-13^{\prime}-\mathrm{CH}_{2} \mathrm{OH}(9 \mathrm{a})$ and $\alpha-\mathrm{T}-13^{\prime}-\mathrm{COOH}(\mathbf{1 2 a})$ were detected at low nanomolar concentrations in human plasma, albeit with strong variation between individuals. ${ }^{6,8,9}$ These differences in 1a metabolism may provide an explanation for the mixed outcomes of human vitamin $\mathrm{E}$ intervention studies ${ }^{8,10,11}$ and open the door toward personalized pharmacotherapy. Notably,
LCMs reach the highest concentration in the liver, which correlates with the recently confirmed clinical efficiency of 1a in nonalcoholic fatty liver disease (NAFLD). ${ }^{12}$

We have shown that $\mathbf{1 2 a}$ accumulates within immune cells at sites of inflammation, such as the inflamed peritoneal cavity of mice, limits the inflammatory reaction in murine peritonitis, and suppresses bronchial hyperreactivity in experimental asthma by targeting 5-lipoxygenase (5-LOX). ${ }^{6}$ LCMs bind to an allosteric site between the 5-LOX catalytic and regulatory domains and inhibit the enzyme at concentrations that are reached in plasma for $\mathbf{1 2 a}{ }^{6}$

Received: May 4, 2021

Published: July 19, 2021 
Scheme 1. Preparation of $\delta$-(Z)-Garcinoic Acid $13 \mathrm{e}^{a}$

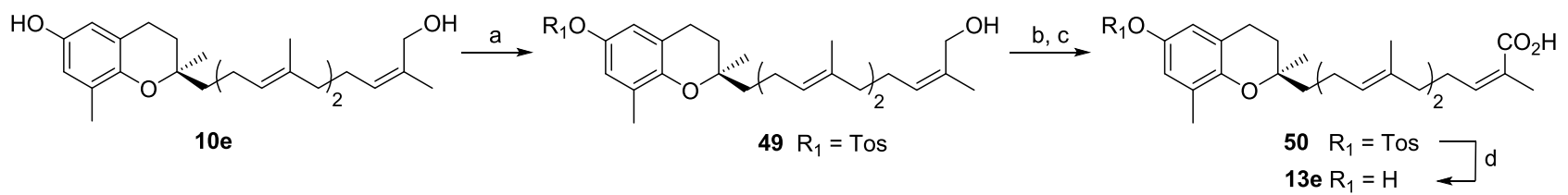

${ }^{a}$ Reagents and conditions: (a) TosCl, Et 3 N, DCM, rt., 2.5 h, 72\%; (b) 2-iodoxybenzoic acid, DCM/DMSO (9:1), $40{ }^{\circ} \mathrm{C}, 6 \mathrm{~h}$; (c) $\mathrm{NaClO}_{2}$, $\mathrm{H}_{2} \mathrm{NSO}_{3} \mathrm{H}$, 2-methyl-2-butene, 1,4-dioxane/ $\mathrm{H}_{2} \mathrm{O}(1: 1), 0{ }^{\circ} \mathrm{C}, 2 \mathrm{~h}, 72 \%$ (2 steps); (d) $\mathrm{NaOH}, \mathrm{MeOH}, 70{ }^{\circ} \mathrm{C}, 3 \mathrm{~h}, 95 \%$.

Scheme 2. General Preparation of Formyltocopherols $2-4^{a}$

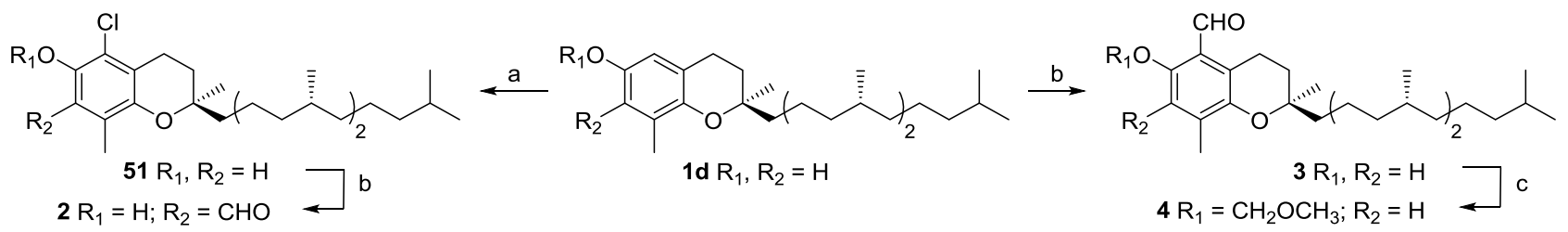

${ }^{a}$ Reagents and conditions: (a) NCS, MeOH, rt., 2 h, 95\%; (b) $\mathrm{MgCl}_{2}, \mathrm{Et}_{3} \mathrm{~N},(\mathrm{CHO}){ }_{n}$, THF, reflux, 75\%; (c) $\mathrm{MOMBr}, n \mathrm{BuLi}, \mathrm{THF},-5{ }^{\circ} \mathrm{C}, 2 \mathrm{~h}$, $80 \%$.

5-LOX initiates the biosynthesis of powerful immunomodulatory lipid mediators from polyunsaturated fatty acids that are released from membrane phospholipids by cytosolic phospholipase $(\mathrm{cPL}) \mathrm{A}_{2}{ }^{13}$ 5-Lipoxygenase-activating protein (FLAP) transfers arachidonic acid to 5-LOX at the nuclear membrane, where leukotriene $(\mathrm{LT}) \mathrm{A}_{4}$ is synthesized via 5hydro(pero)xyeicosatetraenoic acid (5-H(P)ETE) as an intermediate. ${ }^{14} \mathrm{LTA}_{4}$ is converted to either the potent chemoattractant $\mathrm{LTB}_{4}$ or cysteinyl-LTs that elevate vascular permeability and trigger smooth-muscle contraction. ${ }^{15-17}$ LTs are central for asthma and allergic rhinitis and contribute to dermatitis, inflammatory liver disorders, neurodegenerative diseases, cardiovascular disease, and cancer. ${ }^{14,15,18-21}$

5-LOX is also involved in the biosynthesis of lipoxins, resolvins, and other specialized proresolving mediators that orchestrate resolution, pathogen clearance, and tissue regeneration, ${ }^{22,23}$ but the impact of 5-LOX in this process differs between immune cell populations. ${ }^{14,24}$ Remarkably, 12a strongly increased systemic resolvin E3 levels in mice during the resolution phase, whereas the 5-LOX inhibitor zileuton, which is in clinical use for asthma therapy, did not show a comparable effect. ${ }^{6}$ These findings suggest that $12 \mathrm{a}$, besides suppressing acute inflammation, promotes resolution, which would be a major advantage in treating chronic inflammation. 22

Additional targets besides 5-LOX were proposed to contribute to the anti-inflammatory effectiveness of LCMs. Garcinoic acid ( $\delta$-TE-13'-COOH, 13d), a potential LCM with unknown physiological relevance in humans, has agonistic activity on specific nuclear receptors, such as pregnane $\mathrm{X}$ receptor and peroxisome proliferator-activated receptor $\gamma$, a mechanism that is partially shared by other LCMs. ${ }^{25,26}$ Of note, nuclear receptor activation by compound $13 \mathrm{~d}$ has been proposed to diminish Alzheimer's disease progression by interfering with $\beta$-amyloid oligomerization and deposition. ${ }^{27}$ Further immunomodulatory targets were reported for LCMs at supraphysiological concentrations. 13'-Alcohols and 13'carboxylic acids derived from 1a, $\delta$-tocopherol (1d), and $\delta$ tocotrienol (6d) suppress lipopolysaccharide (LPS)-induced signal transduction in macrophages, thereby lowering cytokine release and the expression of proinflammatory enzymes, such as inducible nitric oxide synthase (iNOS) and cyclooxygenase (COX)-2..$^{28-30}$ Moreover, the $13^{\prime}$-carboxylic acid of $\delta$ tocopherol (12b), but not $\alpha$-tocopherol (12a), reduces enzymatic COX-2 activity, ${ }^{6,31}$ and tocotrienol-derived $13^{\prime}$ carboxylic acids $(\mathbf{1 3 a}-\mathbf{d})$ inhibit microsomal prostaglandin $\mathrm{E}_{2}$ synthase (mPGES) $-1,{ }^{32}$ an inducible enzyme that is functionally coupled to COX-2 and responsible for excessive prostaglandin (PG) $\mathrm{E}_{2}$ formation during inflammation. ${ }^{33,34}$ The in vivo relevance of COX-2 and mPGES- 1 inhibition is unclear, ${ }^{35}$ but their moderate inhibition might be beneficial to buffer substrate redirection from LT to PG biosynthesis. ${ }^{36}$

The recent insights into bioactive vitamin $\mathrm{E}$ metabolites promise access to a new generation of 5-LOX-targeting drugs that suppress inflammation without impairing but instead triggering resolution. LCMs potently inhibit 5-LOX, beneficially adjust lipid mediator profiles, and are enriched in immune cells at inflammatory sites. ${ }^{6}$ As endogenous metabolites, they might be less afflicted with toxicity than zileuton and diverse clinical candidates targeting 5-LOX. ${ }^{37}$ Challenges for drug development were, however, the limited knowledge about pharmacophores, the elusive oral availability, and the rapid hepatic LCM metabolism. We here explored the structural requirements for 5-LOX inhibition, taking differences in cellular uptake into account, and identified $\alpha$ amplexichromanol ( $\alpha$-TE-12a $\left.\mathrm{a}^{\prime}, 13^{\prime}-\mathrm{diCH}_{2} \mathrm{OH}, 27 \mathrm{a}\right)$, a highly potent allosteric 5-LOX inhibitor, which combines a favorable pharmacological profile with oral availability and superior metabolic stability. Compound 27a accumulates in immune cells, is efficiently distributed to inflamed regions, and shows anti-inflammatory effectiveness in experimental models of atopic dermatitis in vitro and murine peritonitis and bronchial hyperreactivity in vivo.

\section{RESULTS}

Design and Semisynthesis of Chromanols Inspired from Bioactive Vitamin E Metabolites. Compound 13d was extracted and purified from Garcinia kola nuts according to a previously described method with an optimized yield compared to the literature. ${ }^{39,40}$ Chromanols from the amplexichromanol series $(\mathbf{1 0 e}, \mathbf{2 7 c}, \mathbf{2 7 d})$ were isolated from Garcinia amplexicaulis stem barks. ${ }^{41}$ Both $\alpha$ - and $\beta$-forms (13a, 
Scheme 3. General Preparation of $33,41,46$, and $47^{a}$

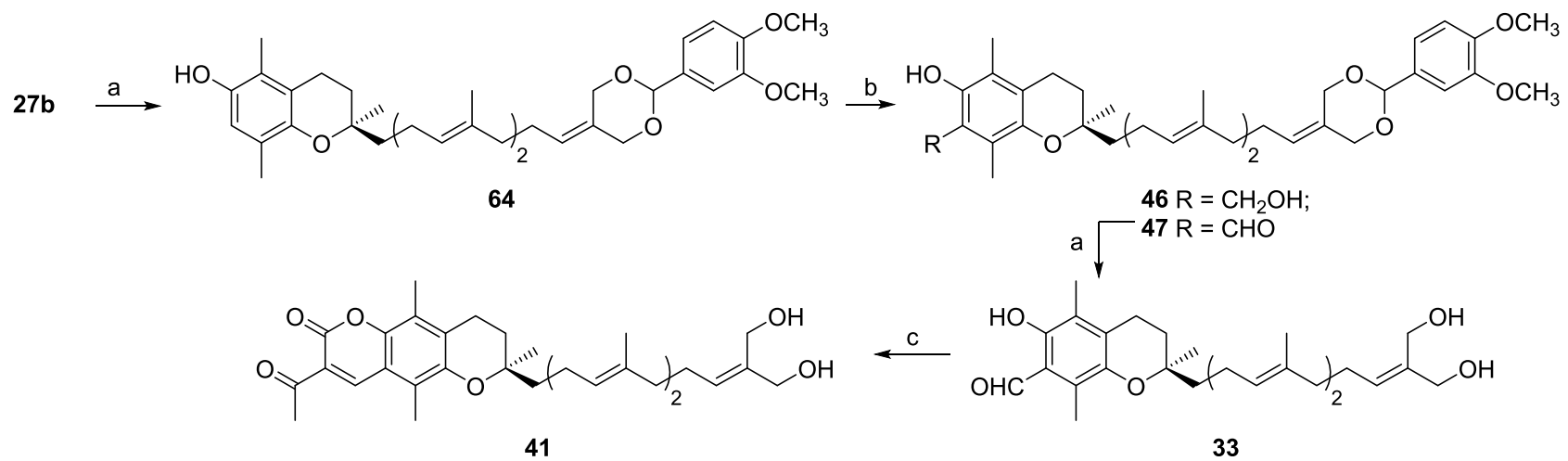

${ }^{a}$ Reagents and conditions: (a) see Alsabil et al.; ${ }^{38}$ (b) $\mathrm{MgCl}_{2}, \mathrm{Et}_{3} \mathrm{~N},(\mathrm{CHO})_{n}$, THF, reflux, 33\% for 46, 36\% for 47; (c) ethyl acetoacetate, piperidine, EtOH, reflux, $89 \%$.

Scheme 4. General Preparation of 15a, 15b, 19a, 19b, 20-22, and $25^{a}$

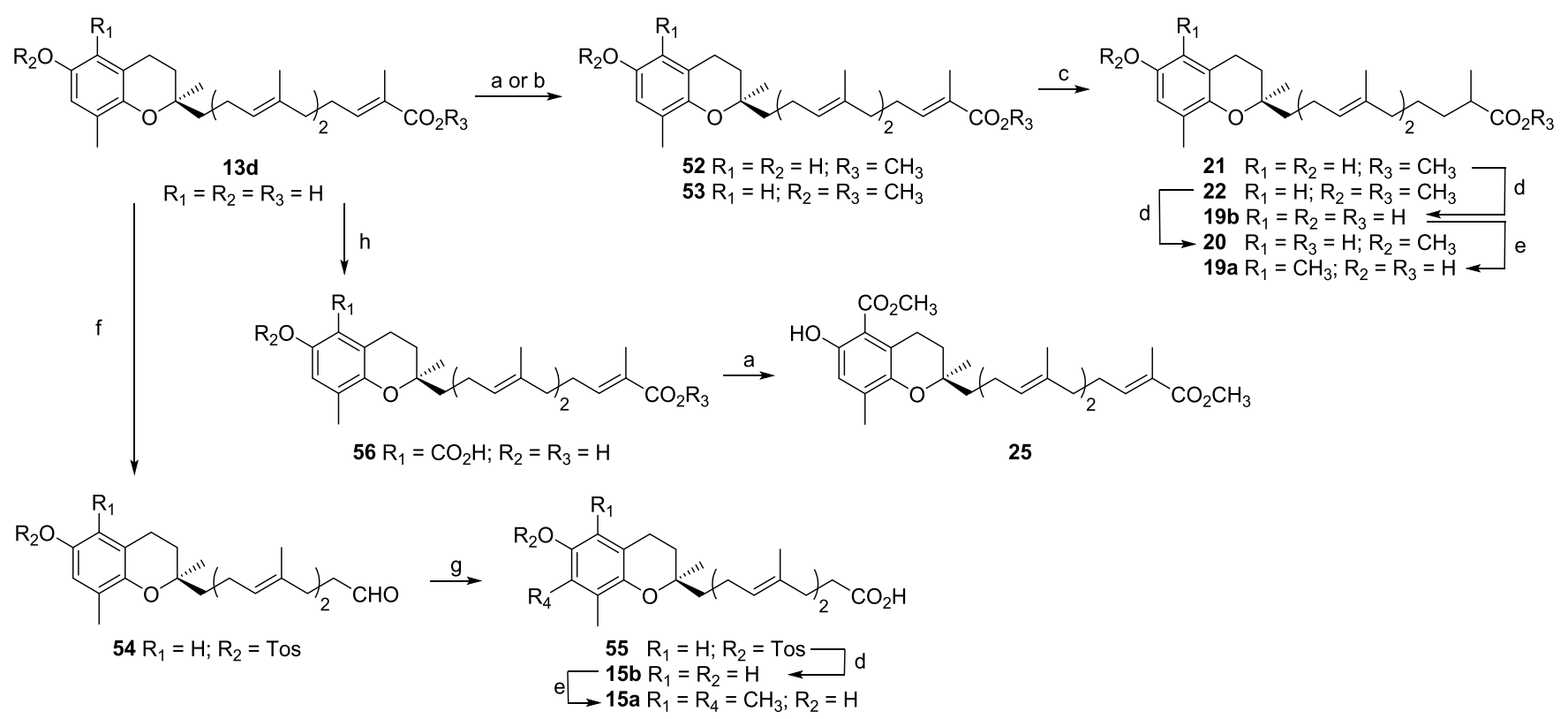

${ }^{a}$ Reagents and conditions: (a) MeI, $\mathrm{NaHCO}_{3}$, DMF, MW $120^{\circ} \mathrm{C}, 45 \mathrm{~min}, 93 \%$ for 52, 85\% for 25; (b) NaH, MeI, DMF, $0{ }^{\circ} \mathrm{C}, 1 \mathrm{~h}, 67 \%$ for 53; (c) $\mathrm{Mg}, \mathrm{MeOH}$, rt., $16 \mathrm{~h}, 66 \%$ for 21, $72 \%$ for 22; (d) $\mathrm{NaOH}, \mathrm{MeOH}, 70{ }^{\circ} \mathrm{C}, 4 \mathrm{~h}, 91 \%$ for $\mathbf{1 9 b}, 87 \%$ for 20, $77 \%$ for $15 \mathbf{b}$; (e) TMDA, (CHO) 1,4-dioxane, MW $140{ }^{\circ} \mathrm{C}, 40 \mathrm{~min}$ and then $\mathrm{NaBH}_{3} \mathrm{CN}, \mathrm{EtOH}$, reflux, $14 \mathrm{~h}, 62 \%$ for $19 \mathrm{a}, 75 \%$ for $15 \mathrm{a}$; (f) see Ville et al.; ${ }^{39}$ (g) $\mathrm{NaClO}_{2}, \mathrm{H}_{2} \mathrm{NSO}_{3} \mathrm{H}$, 2-methyl-2-butene, 1,4-dioxane $/ \mathrm{H}_{2} \mathrm{O}(1: 1), 0{ }^{\circ} \mathrm{C}, 2 \mathrm{~h}$, quant.; (h) see Viault et al. ${ }^{47}$

13b, 27a, 27b) were obtained from the corresponding $\delta$-forms of the garcinoic acid (13d) and amplexichromanol (27d) series through a two-step strategy, which involves the preparation of the mono- or bis-Mannich bases and their reduction with sodium cyanoborohydride. ${ }^{42,43} \delta$-(Z)-Garcinoic acid 13e has been previously isolated from Clusia grandiflora, more specifically from fruits, and subsequently characterized. ${ }^{44}$ In the current study, it was prepared from the corresponding alcohol 10e extracted from the stem barks of this plant and also found in G. amplexicaulis (Scheme 1). Two oxidative steps, namely, 2-iodoxybenzoic acid-mediated and sodium chloritemediated, were applied to the tosyl-protected precursor 49 . Final hydrolysis led to 13 e with $51 \%$ overall yield over four steps.

Formyl derivatives are key intermediates to access a wide variety of functionalized polyphenols (e.g., coumarins, chalcones). Therefore, a $\mathrm{MgCl}_{2}$-mediated formylation was applied to vitamin $\mathrm{E}$ derivatives from different series (tocopherol, tocotrienol, garcinoic acid, amplexichromanol), leading to $2,3,7,8,33,34$, and $47^{38}$ (Scheme 2). Benzyl alcohol 46 was isolated due to an incomplete redox process (Scheme 3). ${ }^{45}$ C5-hydroxymethylation was also evaluated using reagents that prevent formylation such as paraformaldehyde and boric acid. Starting from $\mathbf{7 0}$ allowed the preparation of $48 .{ }^{46}$ Compound 3 was either protected as a methoxymethyl acetal 4 or oxidized through a Pinnick oxidation leading to the corresponding carboxylic acid 5. ${ }^{47}$ Similar conditions applied to aldehyde $\mathbf{5 4 ^ { 3 9 }}$ led to $\mathbf{1 5 b}$ and then $\mathbf{1 5 a}$ bearing a truncated 11-carbon long side-chain (Scheme 4). Aldehydes 33 and 34 were further involved in a condensation step with $\beta$ carbonylesters toward coumarin-tocotrienol hybrids 41-43 (Schemes 3 and 5). ${ }^{48}$

To increase the flexibility of the tail of the side chain and thus potentially improve the binding affinity of the 
Scheme 5. General Preparation of Amplexichromanol Analogues 26, 31, 32, 35-40, 42-45, and $48^{a}$

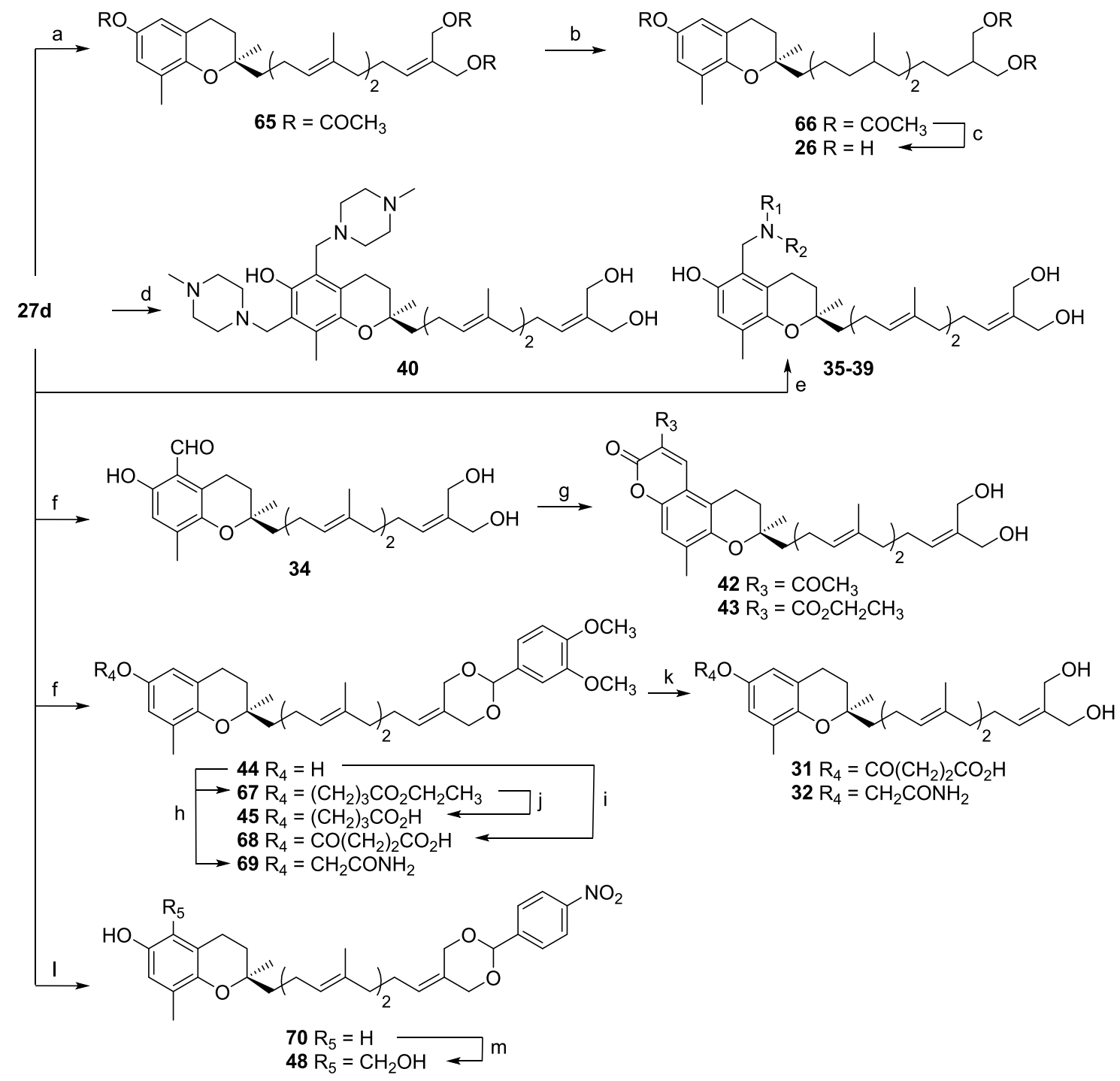

${ }^{a}$ Reagents and conditions: (a) $\left(\mathrm{CH}_{3} \mathrm{CO}\right)_{2} \mathrm{O}$, pyridine, rt., 24 h, 85\%; (b) Pd/C 10\% wt, EtOAc, rt., 40 min, 52\%; (c) $\mathrm{MeONa}, \mathrm{MeOH}$, rt., 40 min, 99\%; (d) (CHO) $)_{n} \mathrm{~N}$-methylpiperazine, $\mathrm{MeOH}$, reflux, $48 \mathrm{~h}, 92 \%$; (e) (CHO) $)_{n}$ secondary amine [= pyrrolidine (35); dimethylamine (36); morpholine (37); piperidine (38); $N$-methylpiperazine (39)], $\mathrm{MeOH}$, reflux, $5 \mathrm{~h}, 90 \%$ for 35, $90 \%$ for 36, 95\% for 37, 95\% for 38, 92\% for 39; (f) see Alsabil et al.; ${ }^{38}$ (g) ethyl acetoacetate (for 42) or diethyl malonate (for 43), piperidine, EtOH, reflux, 1-3 h, 93\% for 42, 90\% for 43; (h) ethyl bromobutyrate (for 67 ) or bromoacetamide (for 69), NaH, THF, $0{ }^{\circ} \mathrm{C}, 4 \mathrm{~h}, 70 \%$ for $67,66 \%$ for 70; (i) succinic anhydride, Et ${ }_{3} \mathrm{~N}, \mathrm{THF}, \mathrm{rt}$., $20 \mathrm{~h}$; (j) LiOH 10\%, THF, rt., 3 h, 85\%; (k) PTSA, THF, 1 h, 60\% for 31, 72\% for 32; (l) 4-nitrobenzaldehyde dimethyl acetal, PTSA, THF, reflux, 5 h, $78 \%$; $(\mathrm{m}) \mathrm{H}_{3} \mathrm{BO}_{3},(\mathrm{CHO})_{n}, \mathrm{AcOH}$, toluene, reflux, $12 \mathrm{~h}, 55 \%$.

corresponding ligands, reduction of the conjugated double bond of garcinoic acids was envisioned. Among different conditions (enzymatic, cobalt-, or copper hydride-catalyzed) reported in the literature and applied to conjugated esters or amides, the use of magnesium in dry methanol was the sole successful approach leading to $\mathbf{2 1}$ and $\mathbf{2 2}$ after a nonstereoselective three-step strategy from 13d (Scheme 4). ${ }^{49-53}$ Hydrogenation of $10 a, 10 c$, and $27 d$, respectively, yielded 9a, $9 \mathrm{~b}$, and 26 as diastereoisomeric mixtures (Scheme 5). ${ }^{54} \mathrm{~A}$ similar conclusion can be drawn for $12 a$ and $12 b$, previously prepared from $13 \mathbf{a}$ and $13 \mathbf{d} .^{28}$

Ruthenium-catalyzed cross-metathesis, applied to a tocotrienolic starting material bearing three double bonds along its side chain, could be considered a powerful combinatorial tool leading in one step to various tocotrienol analogues with shorter side chains. The efficiency of cross-metathesis is known to be dependent on the substitution and the electron density of the alkene reagents. In the present study, three ruthenium catalysts (Grubbs-II, Hoveyda-Grubbs-I, and HoveydaGrubbs-II), tolerant with electron-poor alkenes and monoor disubstituted with various functional groups, were evaluated under different heating conditions and reaction times in deuterated chloroform. ${ }^{55}$ Yields were estimated through HPLC analysis of a crude aliquot from the reaction mixtures. This process confirmed that optimized conditions were both reagent- and catalyst-dependent. Therefore, experimental conditions vary for the metathesis reactions involving tosylated $\delta$-tocotrienol $\mathbf{5 7}$ and methyl acrylate, methyl methacrylate, or 2-methylene-1,3-propanediacetate. Methyl methacrylate was employed to mimic the substitution pattern similar to the garcinoic acid series (Scheme 6). Methyl acrylate led to desmethyl analogues of $13 \mathrm{~d}$ with various side-chain lengths. 
Scheme 6. General Preparation of 14, 16-18, 28, and $29^{a}$

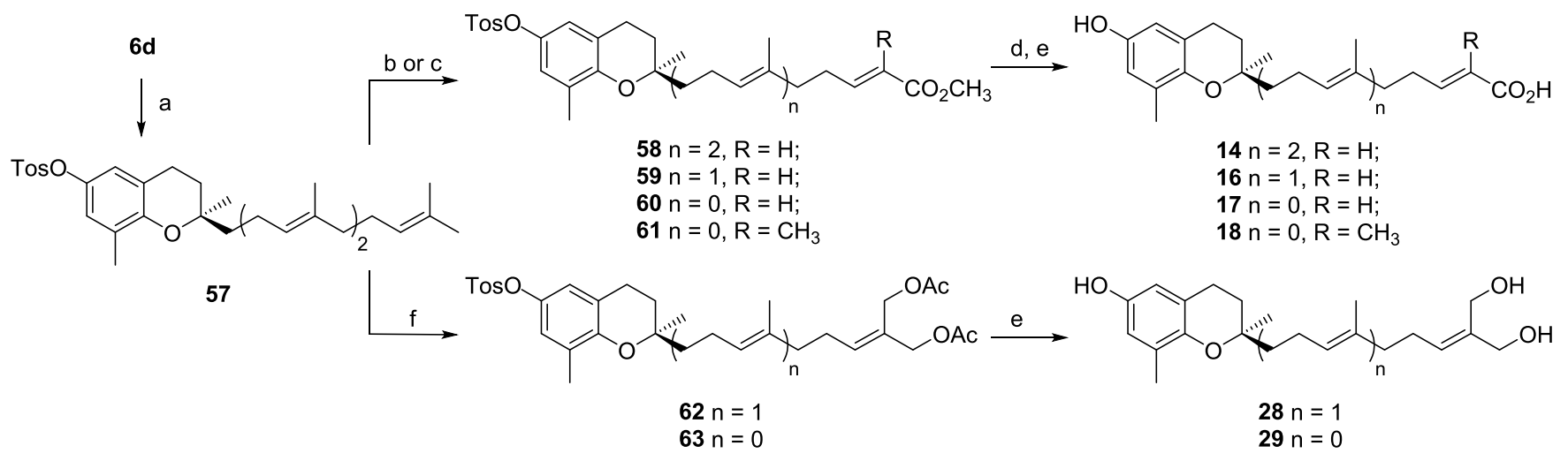

${ }^{a}$ Reagents and conditions: (a) TosCl, $\mathrm{Et}_{3} \mathrm{~N}, \mathrm{DCM}$, rt., 4 h, 60\%; (b) for 58-60 methyl acrylate Grubbs-II catalyst, $\mathrm{CDCl}_{3}$, reflux, 3 days, $10 \%$ for 58, 30\% for 59, 49\% for 60; (c) for 61 methyl methacrylate Hoveyda-Grubbs-II catalyst, $\mathrm{CDCl}_{3}$, MW $120{ }^{\circ} \mathrm{C}, 2.5 \mathrm{~h}, 21 \%$; (d) LiOH, THF/ $\mathrm{MeOH} / \mathrm{H}_{2} \mathrm{O}(3: 1: 1), 40{ }^{\circ} \mathrm{C}, 16 \mathrm{~h}$; (e) $\mathrm{KOH}, \mathrm{MeOH}$, reflux, $6 \mathrm{~h}, 16 \%$ for 14, 31\% for 16, $17 \%$ for 17, 20\% for 18, 53\% for 28, 57\% for 29; (f) 2 methylene-1,3-propanediacetate, Grubbs-II catalyst, $\mathrm{CDCl}_{3}, \mathrm{MW} 120{ }^{\circ} \mathrm{C}, 2 \mathrm{~h}, 27 \%$ for $\mathbf{6 2}, 38 \%$ for 63 .

The third aforementioned alkene reagent, 2-methylene-1,3propanediacetate, helped prepare amplexichromanol analogues. Eventually, 14, 16-18, 28, and 29 were synthesized in our group through a cross-metathesis approach ${ }^{56}$ similar to the one recently reported by Gujarathi et al. ${ }^{57}$ Tosyl ester was used as a protecting group of the phenol function rather than a silylated ether. This choice initially aimed at achieving one final deprotection step of all protecting groups. Practically such a strategy was successfully applied to the syntheses of $\mathbf{2 8}$ and 29 with the parallel removal of acetates and tosylate groups of $\mathbf{6 2}$ and 63. On the other hand, a two-step deprotection sequence was employed to access 14, 16, and 17.

Mannich bases, a chemical class with a wide structural variety, exhibit a broad spectrum of biological activities, including antitumoral, anti-inflammatory, antimicrobial, and antiviral properties. ${ }^{5,59}$ Besides obtaining structural insights from docking studies, we considered optimizing the physicochemical properties of pharmacologically relevant candidates. Water solubility may be further enhanced by adding a protonable group. Therefore, aminomethylation through the Mannich reaction was explored. This strategy has already been applied to $\mathbf{6 d}$ to provide C5-aminomethylated analogues with an antitumoral potential. ${ }^{46}$ In the current study, several mono- and bis-Mannich bases have been prepared either in the garcinoic acid $\left(\mathbf{2 3},{ }^{32} \mathbf{2 4}^{6}\right)$ or in the amplexichromanol (35-40) series following classical experimental conditions (Scheme 5).

Alkylation of the phenol function was potentially associated with a loss of 5-LOX binding affinity for the corresponding tocotrienolic ethers. ${ }^{6}$ Based on reported synthesis methods for the development of redox-silent antitumoral vitamin $\mathrm{E}$ analogues, two ethers $(\mathbf{3 2}, \mathbf{4 5})^{60}$ and one ester $(\mathbf{3 1})^{61}$ bearing both a hydrogen-bond donor and acceptor with different linker lengths were semisynthesized and evaluated (Scheme 5).

Structural Requirements for 5-LOX Inhibition. SAR studies on chromanols as 5-LOX inhibitors were performed both for the isolated human recombinant enzyme (cell-free assay) and in activated human polymorphonuclear leukocytes (PMNL, cell-based assay). $\omega$-Oxidation of tocopherols $(1 \mathbf{a}-\mathbf{d})$ and tocotrienols $(6 \mathbf{a}-\mathbf{d})$ at the 16-carbon side chain led to potent 5-LOX inhibitors with a 13'-hydroxy or 12a'hydroxymethyl group $(\mathbf{9 a}, \mathbf{9 b}, \mathbf{1 0 a}-\mathbf{e}),{ }^{6}$ carboxylic acid $(12 a, 13 a-d),{ }^{6}$ carboxamide, $^{42}$ or methoxycarbonyl substitu- ent (21) (Tables 1 and S1, Schemes S1 and S2). The 5-LOX inhibitory potency was modulated by methyl substitution at the chromanol core, although not always in the same direction for tocopherols $(\mathbf{1 a}-\mathbf{d})$, tocotrienols $(\mathbf{6 a}-\mathbf{d})$, and derivatives with the modified side chain. ${ }^{6}$ Thus, $13 \mathrm{~d}$ is the most potent C13'-carboxylic acid to inhibit 5-LOX, whereas $\omega$-alcohols $(9 a, 9 b, 10 a-c)$ are slightly less potent but also less restricted to side-chain unsaturation (9a vs 10a, 9b vs 10c), the site of $\omega$ oxidation ( $\mathrm{C} 13^{\prime}$ or $12 \mathrm{a}^{\prime} ; 10 \mathrm{~d}, 10 \mathrm{e} v \mathrm{~s} \mathbf{1 3 \mathrm { e }}$ ), and chromanol methylation (e.g., 10a vs 10c in comparison to 13a $v s$ 13d for the 5-LOX enzyme). ${ }^{6}$ Dihydroxylation of one double bond within the side chain was detrimental (27d vs 30) (Tables 2 and S1, Schemes S1 and S2).

We have shown that immune cells strongly accumulate LCMs, with the endogenous vitamin E metabolite 12a being more efficiently enriched than $13 \mathrm{~d}^{6}$ As a consequence, 12a suppressed 5-LOX product biosynthesis in PMNL better than 13d, which was the more potent enzymatic 5-LOX inhibitor (Table 1, Schemes S1 and S2). This gain of potency in PMNL was limited to side-chain saturated derivatives and not evident for the respective $\alpha$-garcinoic acid 13a. Together, substantial differences in the SARs of 5-LOX inhibition exist between cellfree and cell-based assays. The challenge was to enhance 5LOX inhibition while maintaining an efficient uptake of the vitamin E-inspired compounds into immune cells.

Starting from $13 a-d$ as promising leads, we focused on the length and functionalization of the side chain and explored options for chromanol substitution. Both inhibition of cell-free 5-LOX activity and the biosynthesis of 5-LOX products in activated PMNL were addressed (Table 1, Schemes S1 and S2). In a first step, we varied the side-chain length (14, 15a, $15 b, 16)$ and found that inhibition of 5-LOX activity consistently decreased with shorter chain length within the $\delta$-series $(14,15 b, 16)$, both in cell-free and in cell-based assays. Side-chain shortening of the $\alpha$-derivative 13a (from C13 to C11) yielding 15a was instead tolerated. We then addressed side-chain methylation, saturation, and chain length and found that 5-LOX inhibition was impaired for the desmethyl analogue at the $\mathrm{C} 12$ position (14) as well as by saturation of the $\Delta 11^{\prime}, 12^{\prime}$ double bond $(19 a, 19 b)$ and absent when truncated to $\mathrm{C5}$ side chains $(17,18)$. Together, the natural LCM 13d excels in 5-LOX inhibition within this series of sidechain scaffold modifications. 
Table 1. Inhibition of Human Isolated 5-LOX and 5-LOX Product Formation in Activated PMNL by Garcinoic Acid-Derived Compounds $(12 a-25)^{e}$

\begin{tabular}{|c|c|c|c|c|c|c|c|c|}
\hline \multirow[t]{2}{*}{ Compound } & \multirow{2}{*}{\multicolumn{2}{|c|}{$\begin{array}{c}\text { Structure } \\
\text { R2 }\end{array}$}} & \multirow[b]{2}{*}{ R3 } & \multirow[b]{2}{*}{ R4 } & \multicolumn{2}{|c|}{$\begin{array}{l}\text { 5-LOX } \\
\text { enzyme }\end{array}$} & \multicolumn{2}{|c|}{$\begin{array}{l}\text { 5-LOX } \\
\text { PMNL }\end{array}$} \\
\hline & & & & & $\mathrm{IC}_{50}[\mu \mathrm{M}]^{\mathrm{a}}$ & $\begin{array}{c}\text { at } 1 \mu \mathrm{M} \\
{[\%]^{\mathrm{b}}}\end{array}$ & $\mathrm{IC}_{50}[\mu \mathrm{M}]^{\mathrm{a}}$ & $\begin{array}{c}\text { at } 3 \mu \mathrm{M} \\
{[\%]^{\mathrm{c}}} \\
\end{array}$ \\
\hline $12 a$ & $\mathrm{CH}_{3}$ & $\mathrm{H}$ & $\mathrm{CH}_{3}$ & & $0.27 \pm 0.01^{\mathrm{d}}$ & $0.8 \pm 0.2$ & $0.08 \pm 0.00^{\mathrm{d}}$ & $2.0 \pm 0.8$ \\
\hline $12 \mathrm{~b}$ & $\mathrm{H}$ & $\mathrm{H}$ & $\mathrm{H}$ & & $>1^{\mathrm{d}}$ & $51.4 \pm 3.1$ & $2.01 \pm 0.59^{d}$ & $40.8 \pm 3.5$ \\
\hline 13a & $\mathrm{CH}_{3}$ & $\mathrm{H}$ & $\mathrm{CH}_{3}$ & & $0.40 \pm 0.08^{\mathrm{d}}$ & $11.4 \pm 4.9$ & $0.56 \pm 0.18$ & $12.2 \pm 1.8$ \\
\hline 13b & $\mathrm{CH}_{3}$ & $\mathrm{H}$ & $\mathrm{H}$ & & $0.15 \pm 0.04^{d}$ & $0.8 \pm 0.3$ & $0.31 \pm 0.11^{\mathrm{d}}$ & $5.1 \pm 1.3$ \\
\hline $13 \mathrm{c}$ & $\mathrm{H}$ & $\mathrm{H}$ & $\mathrm{CH}_{3}$ & & $0.30 \pm 0.10^{d}$ & $4.1 \pm 3.6$ & $0.49 \pm 0.03^{d}$ & $1.6 \pm 1.6$ \\
\hline 13d & $\mathrm{H}$ & $\mathrm{H}$ & $\mathrm{H}$ & & $0.06 \pm 0.01^{\mathrm{d}}$ & $1.4 \pm 0.8$ & $0.35 \pm 0.07^{\mathrm{d}}$ & $0.4 \pm 0.2$ \\
\hline $13 \mathrm{e}$ & H & $\mathrm{H}$ & $\mathrm{H}$ & & $0.18 \pm 0.05$ & $9.6 \pm 4.5$ & $0.63 \pm 0.18$ & $3.4 \pm 0.5$ \\
\hline 14 & $\mathrm{H}$ & $\mathrm{H}$ & $\mathrm{H}$ & & $0.44 \pm 0.08$ & $24.5 \pm 2.8$ & $2.20 \pm 0.14$ & $26.9 \pm 4.8$ \\
\hline $15 a$ & $\mathrm{CH}_{3}$ & $\mathrm{H}$ & $\mathrm{CH}_{3}$ & & $0.44 \pm 0.07$ & $11.5 \pm 1.8$ & $0.45 \pm 0.12$ & $10.6 \pm 5.8$ \\
\hline $15 b$ & $\mathrm{H}$ & $\mathrm{H}$ & $\mathrm{H}$ & & $0.47 \pm 0.14$ & $28.8 \pm 5.2$ & $2.19 \pm 0.40$ & $32.0 \pm 9.8$ \\
\hline 16 & $\mathrm{H}$ & $\mathrm{H}$ & $\mathrm{H}$ & & $0.92 \pm 0.04$ & $47.3 \pm 1.1$ & $>3$ & $77.0 \pm 3.9$ \\
\hline 17 & $\mathrm{H}$ & $\mathrm{H}$ & $\mathrm{H}$ & & $>1$ & $65.3 \pm 25.2$ & $>3$ & $101.4 \pm 5.2$ \\
\hline 18 & $\mathrm{H}$ & $\mathrm{H}$ & $\mathrm{H}$ & & $>1$ & $56.4 \pm 18.3$ & $>3$ & $88.8 \pm 6.4$ \\
\hline 19a & $\mathrm{CH}_{3}$ & $\mathrm{H}$ & $\mathrm{H}$ & & $0.81 \pm 0.08$ & $41.2 \pm 6.2$ & $0.81 \pm 0.33$ & $14.2 \pm 6.5$ \\
\hline 19b & $\mathrm{H}$ & $\mathrm{H}$ & $\mathrm{H}$ & & $0.17 \pm 0.04^{\mathrm{d}}$ & $7.4 \pm 2.7$ & $0.61 \pm 0.15$ & $3.8 \pm 0.8$ \\
\hline 20 & $\mathrm{H}$ & $\mathrm{CH}_{3}$ & $\mathrm{H}$ & & $>1$ & $98.1 \pm 1.3$ & n.d. & n.d. \\
\hline 21 & $\mathrm{H}$ & $\mathrm{H}$ & $\mathrm{H}$ & & $0.17 \pm 0.01$ & $5.8 \pm 1.7$ & $1.14 \pm 0.39$ & $14.1 \pm 6$ \\
\hline 22 & $\mathrm{H}$ & $\mathrm{CH}_{3}$ & $\mathrm{H}$ & & $>1$ & $88.7 \pm 4.3$ & n.d. & n.d. \\
\hline 23 & $\mathrm{CH}_{2} \mathrm{~N}\left(\mathrm{CH}_{3}\right)_{2}$ & $\mathrm{H}$ & $\mathrm{H}$ & & $0.07 \pm 0.02$ & $7.9 \pm 3.6$ & $2.06 \pm 0.45$ & $33.1 \pm 8.0$ \\
\hline 24 & $\mathrm{CH}_{2} \mathrm{~N}\left(\mathrm{CH}_{3}\right)_{2}$ & $\mathrm{H}$ & $\mathrm{CH}_{2} \mathrm{~N}\left(\mathrm{CH}_{3}\right)_{2}$ & & $>1$ & $95.2 \pm 7.9$ & $>3$ & $82.1 \pm 24.1$ \\
\hline 25 & $\mathrm{CO}_{2} \mathrm{CH}_{3}$ & $\mathrm{H}$ & $\mathrm{H}$ & & $>1$ & $54.5 \pm 8.4$ & $>3$ & $79.9 \pm 3.6$ \\
\hline
\end{tabular}

${ }^{a} \mathrm{IC}_{50}$ values $(\mu \mathrm{M}) .{ }^{b}$ Residual activities (\% control) at $1 \mu \mathrm{M}$ compound concentration. ${ }^{c}$ Residual activities (\% control) at $3 \mu \mathrm{M}$ compound concentration. ${ }^{d}$ Highlighted data (gray) are from Pein et al. ${ }^{6}$ n.d., not determined. ${ }^{e}$ All values are given as mean \pm standard error of the mean (SEM) of single determinations obtained in 3-6 independent experiments.

Next, we investigated whether $\omega$-oxidation at both $\mathrm{C} 13^{\prime}$ and C12a' potentiates 5-LOX inhibition. In fact, $12 \mathrm{a}^{\prime} / 13^{\prime}-$ dihydroxylated tocotrienol analogues $(27 \mathbf{a}-\mathbf{c})$ belonging to the amplexichromanol series inhibited cell-free 5-LOX (27a: 
Table 2. Inhibition of Human Isolated 5-LOX and 5-LOX Product Formation in Activated PMNL by AmplexichromanolDerived Compounds $(26-48)^{e}$

\begin{tabular}{|c|c|c|c|c|c|c|c|c|}
\hline \multirow[t]{2}{*}{ Compound } & \multirow{2}{*}{\multicolumn{2}{|c|}{$\begin{array}{c}\text { Structure } \\
\text { R2 } \\
\end{array}$}} & \multirow[b]{2}{*}{ R3 } & \multirow[b]{2}{*}{ R4 } & \multicolumn{2}{|c|}{$\begin{array}{l}\text { 5-LOX } \\
\text { enzyme }\end{array}$} & \multicolumn{2}{|c|}{$\begin{array}{l}\text { 5-LOX } \\
\text { PMNL }\end{array}$} \\
\hline & & & & & $\mathrm{IC}_{50}[\boldsymbol{\mu M}]^{\mathrm{a}}$ & $\begin{array}{c}\text { at } 1 \mu \mathrm{M} \\
{[\%]^{\mathrm{b}}} \\
\end{array}$ & $\mathrm{IC}_{50}[\mu \mathrm{M}]^{\mathrm{a}}$ & $\begin{array}{c}\text { at } 3 \mu \mathrm{M} \\
{[\%]^{\mathrm{c}}} \\
\end{array}$ \\
\hline 26 & $\mathrm{H}$ & $\mathrm{H}$ & $\mathrm{H}$ & & $>1$ & $53.1 \pm 7.4$ & $>3$ & $81.3 \pm 0.7$ \\
\hline $27 \mathbf{a}$ & $\mathrm{CH}_{3}$ & $\mathrm{H}$ & $\mathrm{CH}_{3}$ & & $0.11 \pm 0.03$ & $0.1 \pm 0.0$ & $0.04 \pm 0.01$ & $0.5 \pm 0.1$ \\
\hline $27 \mathrm{~b}$ & $\mathrm{CH}_{3}$ & $\mathrm{H}$ & $\mathrm{H}$ & & $0.09 \pm 0.02$ & $0.0 \pm 0.0$ & $0.10 \pm 0.02$ & $0.9 \pm 0.5$ \\
\hline $27 \mathrm{e}$ & $\mathrm{H}$ & $\mathrm{H}$ & $\mathrm{CH}_{3}$ & & $0.11 \pm 0.00^{d}$ & $0.1 \pm 0.1$ & $0.05 \pm 0.04$ & $0.8 \pm 0.2$ \\
\hline $27 \mathrm{~d}$ & $\mathrm{H}$ & $\mathrm{H}$ & $\mathrm{H}$ & & $0.15 \pm 0.04^{d}$ & $1.8 \pm 0.9$ & $0.43 \pm 0.04$ & $14.7 \pm 1.6^{b}$ \\
\hline 28 & $\mathrm{H}$ & $\mathrm{H}$ & $\mathrm{H}$ & & $0.17 \pm 0.03$ & $15.0 \pm 2.4$ & $2.30 \pm 0.26$ & $36.3 \pm 6.5$ \\
\hline 29 & $\mathrm{H}$ & $\mathrm{H}$ & $\mathrm{H}$ & & $>1$ & $79.7 \pm 3.5$ & $>3$ & $86.4 \pm 0.8$ \\
\hline 30 & $\mathrm{H}$ & $\mathrm{H}$ & $\mathrm{H}$ & & $0.38 \pm 0.11$ & $12.2 \pm 4.1$ & n.d. & n.d. \\
\hline 31 & $\mathrm{H}$ & & $\mathrm{H}$ & & $0.09 \pm 0.03$ & $1.1 \pm 0.6$ & $0.45 \pm 0.10$ & $26.4 \pm 6.7^{b}$ \\
\hline 32 & $\mathrm{H}$ & $\frac{3}{4}$ & $\mathrm{H}$ & & $>1$ & $99.8 \pm 5.6$ & n.d. & n.d. \\
\hline 33 & $\mathrm{CH}_{3}$ & $\mathrm{H}$ & СHO & & $0.17 \pm 0.05$ & $8.9 \pm 3.5$ & $1.38 \pm 0.28$ & $7.5 \pm 2.2$ \\
\hline 34 & Сно & $\mathrm{H}$ & $\mathrm{H}$ & & $0.17 \pm 0.06$ & $13.8 \pm 4.4$ & $1.81 \pm 0.32$ & $6.1 \pm 0.1$ \\
\hline 35 & & $\mathrm{H}$ & $\mathrm{H}$ & & $0.17 \pm 0.03$ & $4.1 \pm 0.2$ & $1.90 \pm 0.11$ & $17.4 \pm 2.4$ \\
\hline 36 & $\mathrm{H}_{2} \mathrm{~N}\left(\mathrm{CH}_{3}\right)_{2}$ & $\mathrm{H}$ & $\mathrm{H}$ & & $0.11 \pm 0.02$ & $3.7 \pm 0.4$ & $>3$ & $63.9 \pm 14.4$ \\
\hline 37 & & $\mathrm{H}$ & $\mathrm{H}$ & & $0.12 \pm 0.03$ & $3.9 \pm 0.6$ & $1.74 \pm 0.09$ & $11.3 \pm 3.3$ \\
\hline 38 & & $\mathrm{H}$ & $\mathrm{H}$ & & $0.11 \pm 0.02$ & $5.1 \pm 0.9$ & $1.95 \pm 0.07$ & $11.7 \pm 1.8$ \\
\hline 39 & & $\mathrm{H}$ & $\mathrm{H}$ & & $0.31 \pm 0.07$ & $16.0 \pm 1.9$ & $2.03 \pm 0.16$ & $21.6 \pm 6.8$ \\
\hline 40 & & $\mathrm{H}$ & & & $>1$ & $50.3 \pm 4.1$ & $>3$ & $77.8 \pm 7.6$ \\
\hline 41 & $\mathrm{CH}_{3}$ & & & & $0.63 \pm 0.13$ & $35.1 \pm 5.7$ & $1.25 \pm 0.20$ & $12.4 \pm 0.7$ \\
\hline
\end{tabular}


Table 2. continued

\begin{tabular}{|c|c|c|c|c|c|c|c|c|}
\hline \multirow[t]{2}{*}{ Compound } & \multirow[b]{2}{*}{ R1 } & \multirow{2}{*}{$\begin{array}{l}\text { tructure } \\
\text { R2 }\end{array}$} & \multirow[b]{2}{*}{$\mathbf{R 3}$} & \multirow[b]{2}{*}{ R4 } & \multicolumn{2}{|c|}{$\begin{array}{c}\text { 5-LOX } \\
\text { enzyme }\end{array}$} & \multicolumn{2}{|c|}{$\begin{array}{l}\text { 5-LOX } \\
\text { PMNL }\end{array}$} \\
\hline & & & & & $\mathrm{IC}_{50}[\boldsymbol{\mu M}]^{\mathrm{a}}$ & $\begin{array}{c}\text { at } 1 \mu \mathrm{M} \\
{[\%]^{\mathrm{b}}}\end{array}$ & $\mathrm{IC}_{50}[\mu \mathrm{M}]^{\mathrm{a}}$ & $\begin{array}{c}\text { at } 3 \mu \mathrm{MM} \\
{[\%]^{\mathrm{c}}}\end{array}$ \\
\hline 42 & & & $\mathrm{H}$ & & $0.21 \pm 0.02$ & $23.3 \pm 2.3$ & $1.44 \pm 0.42$ & $15.3 \pm 6.9$ \\
\hline 43 & & & $\mathrm{H}$ & & $0.47 \pm 0.14$ & $29.3 \pm 2.6$ & $1.58 \pm 0.21$ & $8.1 \pm 1.0$ \\
\hline 44 & $\mathrm{H}$ & $\mathrm{H}$ & $\mathrm{H}$ & & $0.21 \pm 0.14$ & $12.7 \pm 9.3$ & n.d. & n.d. \\
\hline 45 & $\mathrm{H}$ & $\omega^{3}$ & $\mathrm{H}$ & & $>1$ & $83.0 \pm 7.6$ & n.d. & n.d. \\
\hline 46 & $\mathrm{CH}_{3}$ & $\mathrm{H}$ & $\mathrm{CH}_{2} \mathrm{OH}$ & & $0.09 \pm 0.00$ & $0.7 \pm 0.1$ & $0.39 \pm 0.18$ & $22.2 \pm 8.8$ \\
\hline 47 & $\mathrm{CH}_{3}$ & $\mathrm{H}$ & $\mathrm{CHO}$ & & $>1$ & $58.7 \pm 4.6$ & $>3$ & $84.0 \pm 8.5$ \\
\hline 48 & $\mathrm{CH}_{2} \mathrm{OH}$ & $\mathrm{H}$ & $\mathrm{H}$ & & $0.21 \pm 0.13$ & $14.0 \pm 3.2$ & $0.49 \pm 0.13$ & $15.4 \pm 1.9$ \\
\hline
\end{tabular}

${ }^{a} \mathrm{IC}_{50}$ values $(\mu \mathrm{M}) .{ }^{b}$ Residual activities (\% control) at $1 \mu \mathrm{M}$ compound concentration. ${ }^{c}$ Residual activities (\% control) at $3 \mu \mathrm{M}$ compound concentration. ${ }^{d}$ Highlighted data (gray) are from Pein et al. ${ }^{6}$ n.d., not determined. ${ }^{e}$ All values are given as mean \pm SEM of single determinations obtained in 3-4 independent experiments.

$\left.\mathrm{IC}_{50}=0.11 \mu \mathrm{M}\right)$ better than $\omega$-carboxylic acids $(13 \mathbf{a}-\mathbf{c})$, except for the $\delta$-derivative $27 \mathrm{~d}$, which was less potent than $\mathbf{1 3 d}$ (Tables 1 and 2, Schemes S1 and S2). We hypothesize that the methylation pattern of the chromanol core (as found in natural vitamin $\mathrm{E}$ forms) impacts cellular uptake and thus 5-LOX inhibition. In support of this hypothesis, the inhibitory activity of $\alpha$-amplexichromanol 27a further increased in PMNL ( $\mathrm{IC}_{50}$ $=0.04 \mu \mathrm{M})$, thereby exceeding the potency of the endogenous metabolite 12a $\left(\mathrm{IC}_{50}=0.08 \mu \mathrm{M}\right){ }^{6}$ The $\beta$ - and $\gamma$-analogues $27 \mathrm{~b}$ and $27 \mathrm{c}$ maintained their activity in the cell-based assay, whereas $\delta$-amplexichromanol $\mathbf{2 7 d}$ was less effective, which again highlights the strong influence of chromanol substitution on cell-based 5-LOX product formation. Shortening to C9 (28) or C5 (29) side chains was detrimental, especially in the cell-based assay, and also side-chain saturation of $27 \mathrm{~d}$ yielding 26 was not tolerated. Ring closure of the $12 \mathrm{a}^{\prime}, 13^{\prime}$-diol to substituted 1,3-dioxans (44-48) was explored because we previously found that bulky substituents, even without the hydrogen bridge donor, are tolerated in the $\omega$-position. ${ }^{6,42}$ Some of the obtained 1,3-dioxanes potently inhibited cell-free 5-LOX although they were less effective in suppressing 5-LOX product formation in PMNL than 27a. Together, compound 27a carries an optimized side chain that qualifies for potent 5LOX inhibition in cell-free and cell-based assays, thereby fulfilling the structural requirements for efficient 5-LOX binding and cellular accumulation.
We concentrated our further efforts on the chromanol moiety. Molecular docking studies suggest that the chromanol hydroxyl group is critical for the interaction with 5-LOX. ${ }^{6}$ In fact, O-methylation $(\mathbf{2 0}, \mathbf{2 2})$ abolished 5-LOX inhibition by the $\omega$-carboxylic acids $19 \mathrm{~b}$ and 21 , and ring closure as coumarin (a scaffold found in potent 5-LOX inhibitors ${ }^{62}$ ) under formation of an annulated 2-oxobenzopyran (41) was also disadvantageous (Tables 1 and 2, Schemes S1 and S2). Accordingly, replacement of the phenolic alcohol by an aminocarbonylmethoxy group (32) to increase the distance between the chromanol core and the hydrogen-bond donor/ acceptor function was associated with a loss of inhibitory potency. On the other hand, 5-LOX inhibition was slightly enhanced in the cell-free assay by introducing a free carboxylic acid group as the $O$-succinyl ester (31). In activated PMNL, 31 inhibited 5-LOX comparably to $27 \mathrm{~d}$, potentially because the ester in $\mathbf{3 1}$ is intracellularly cleaved to the free hydroxyl group of $27 \mathrm{~d}$

We then investigated whether also oxidative modifications at the chromanol core lead to potent 5-LOX inhibitors, as yielded by $\omega$-oxidation of the unsaturated side chain. However, neither oxidation of the C5 or C7 methyl groups to an aldehyde (3, 4, 7) or carboxylic acid (5) nor additional halogenation $(2,8)$ had any improving effect (Table S1, Schemes S1 and S2). The replacement of the $\mathrm{C} 5$ or $\mathrm{C} 7$ methyl groups by an aldehyde $(33,34)$ or hydroxymethyl moiety $(46,48)$ was, on the other hand, compatible with potent 5-LOX inhibition when 


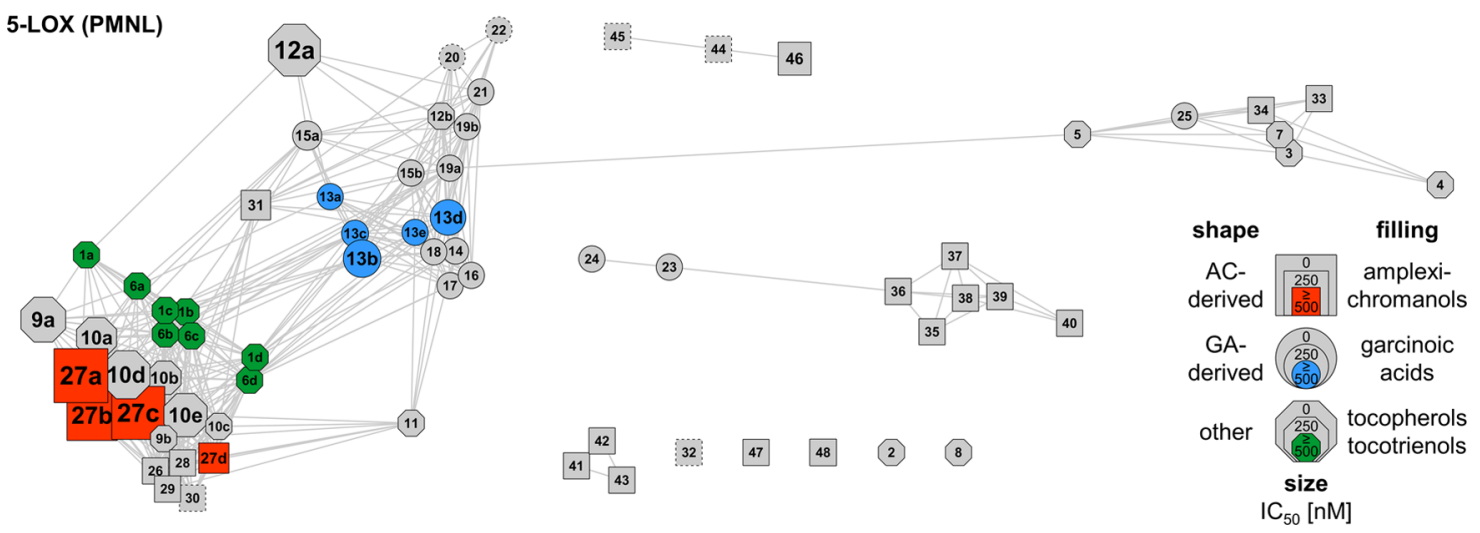

Figure 1. Correlation network of the compound library for inhibition of 5-LOX in PMNL. The network visualizes structural similarity between compounds calculated using Tanimoto similarity. Nodes represent individual compounds, and connecting edges represent Tanimoto coefficients $>$ 0.9. The node shape differentiates between derivatives derived from amplexichromanols (AC), garcinoic acids (GA), or other leads, and the filling highlights the parental series, i.e., amplexichromanol (red), garcinoic acid (blue), tocopherol, and tocotrienol (green). The node size reflects the potency ( $\mathrm{IC}_{50}$ values) of the compound to inhibit 5-LOX product formation in PMNL. For nodes with dotted lines, $\mathrm{IC}_{50}$ values were not determined.

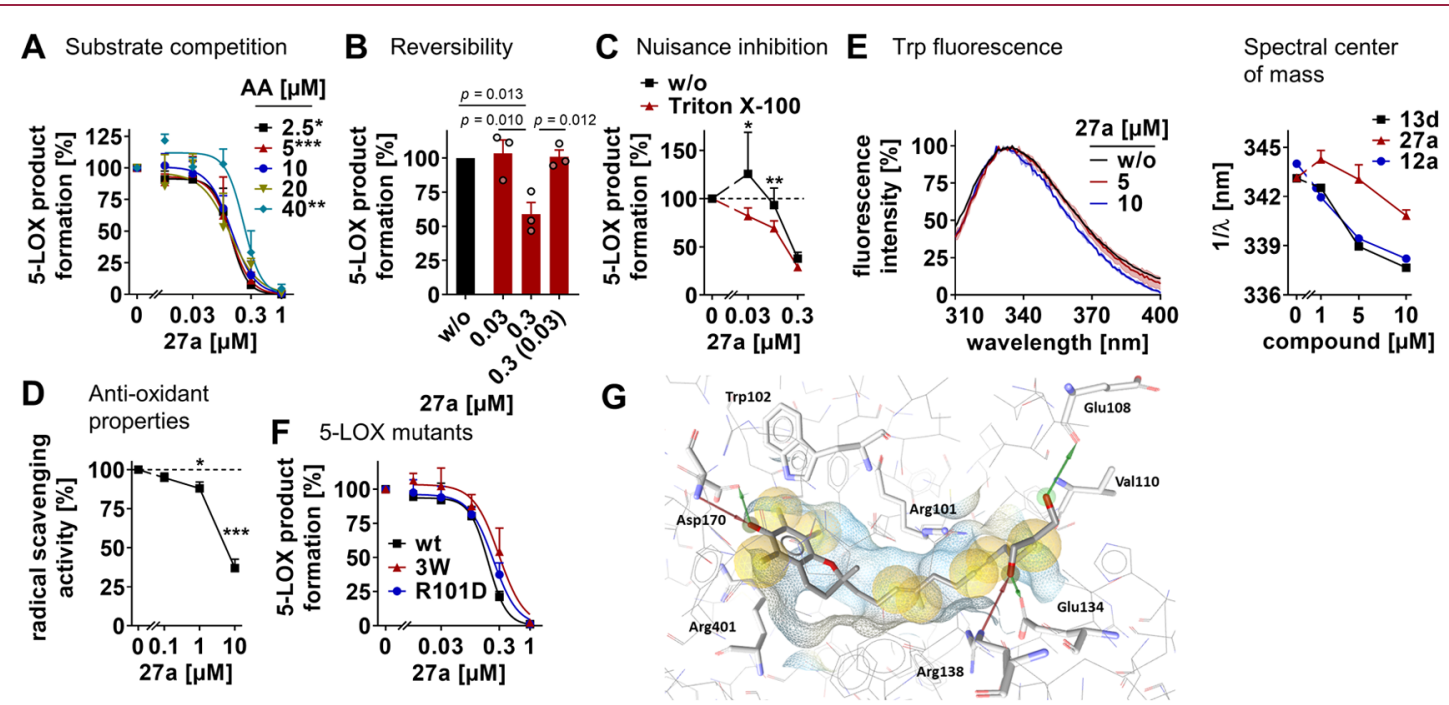

Figure 2. Molecular insights into 5-LOX inhibition by 27a. (A) Effect of the arachidonic acid (AA) concentration on 5-LOX inhibition by 27a. (B) Reversibility of 5-LOX inhibition by $27 \mathrm{a}$. Samples were preincubated with a vehicle or compound for $15 \mathrm{~min}, 10$-fold diluted, and incubated for another 5 min before AA was added. The number in brackets indicates the diluted compound concentration after preincubation. (C) Effect of Triton X-100 (0.01\%) on 5-LOX inhibition by 27a. (D) Scavenging of DPPH radicals by 27a. (E) Fluorescence excitation spectra as a percentage of maximum fluorescence intensity (left panel) and spectral center of mass of the fluorescence emission variations (right panel) shown for 5-LOX titrated with 13d, 27a, or 12a. (F) Effect of 27a on the inhibition of wild-type 5-LOX (wt), the triple mutant Trp13Ala, Trp75Ala, and Trp102Ala 5-LOX (3W), and the single mutant Arg101Asp 5-LOX (R101D). (G) Molecular docking pose of 27a in the allosteric binding site of 5-LOX showing the interaction with Asp170, Arg138, Glu134, and Glu108. Hydrogen bonds are shown as red (HBA) and green (HBD) arrows and hydrophobic contacts as yellow spheres. Data are expressed as mean \pm SEM (A-D, F) with single values (B) or mean \pm SEM (transparent area) from $n=2(\mathrm{E}), n=3(\mathrm{~A}-\mathrm{C})$, and $n=4(\mathrm{D}, \mathrm{F})$ independent experiments. $* p<0.05, * * p<0.01, * * *<<0.001 v s 20 \mu \mathrm{M} \mathrm{AA}$ (A), control (D), absence of Triton X-100 (C), wt 5-LOX (F), or as indicated (B); two-way ANOVA + Tukey's post hoc test (A, F), RM one-way ANOVA + Tukey's post hoc test $(\mathrm{B}, \mathrm{D})$, two-tailed paired $t$-test of log data $(\mathrm{C})$.

combined with $\omega$-oxidation of the side chain. Motivated by this finding, we explored a variety of structurally diverse substituents. Introduction of a methyl ester residue at the C5 methyl group of $\mathbf{1 3 d}$ in combination with methylation of the $13^{\prime}$-carboxylic function was detrimental (25), whereas basic tertiary amines and N-heterocycles yielded inhibitors of cellfree 5-LOX that were comparably potent to the nonsubstituted derivative (for pyrrolidino, 35; for dimethylamino, 23, 36; for morpholino, 37; or for piperidinyl substitution, 38). An additional more distant nitrogen atom ( $N$-methyl-piperazinyl, 39) was detrimental, and substitution of both $\mathrm{C5}$ and $\mathrm{C7}$ positions with dialkylated aminomethyl groups $(\mathbf{2 4}, \mathbf{4 0})$ was not tolerated. While substituents at C5 and C7 of chromanol provide limited options to improve 5-LOX inhibition, all of these modifications substantially impaired the suppression of 5-LOX product biosynthesis in PMNL (Tables 1 and 2, Schemes S1 and S2), and we conclude that the natural chromanol moiety of vitamin $\mathrm{E}$ already represents an evolutionally optimized compromise between potent 5-LOX inhibition and access to the enzyme in innate immune cells. The $12 \mathrm{a}^{\prime}, 13^{\prime}$-dihydroxylated $\alpha$-tocotrienol $27 \mathrm{a}$ combines these features and was selected as a promising drug candidate for further pharmacological studies. 

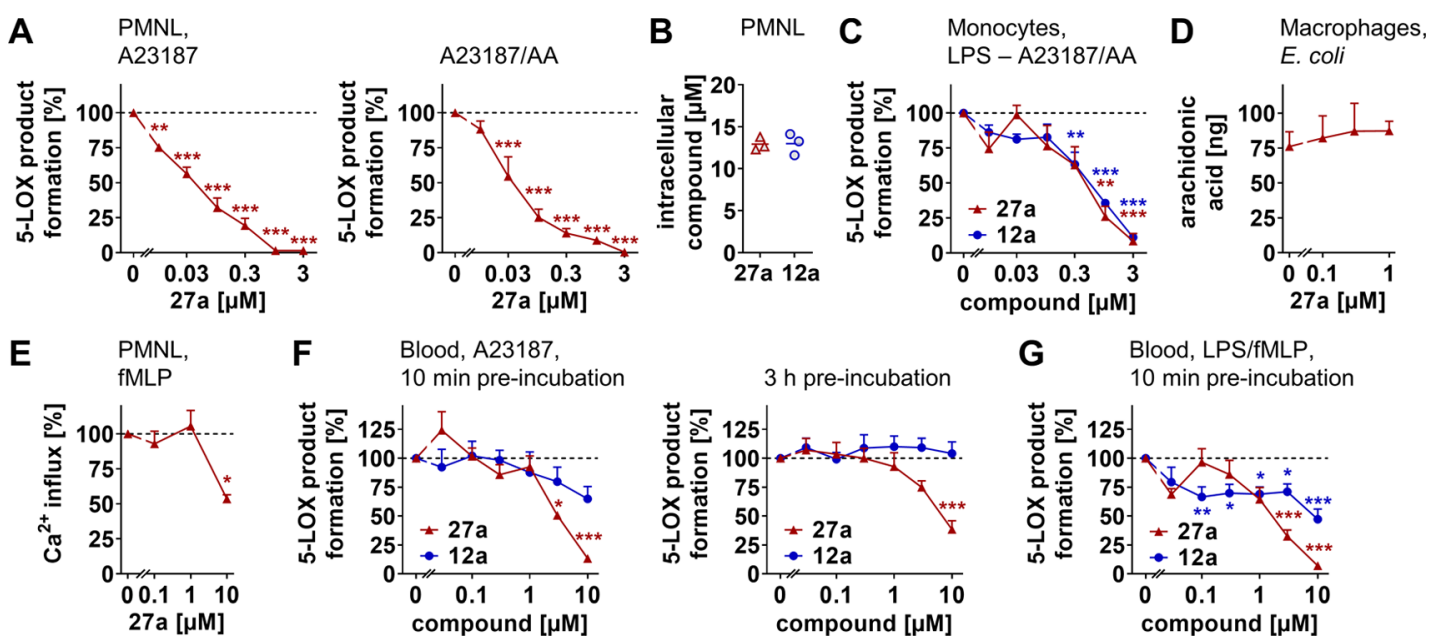

G Blood, LPS/FMLP,

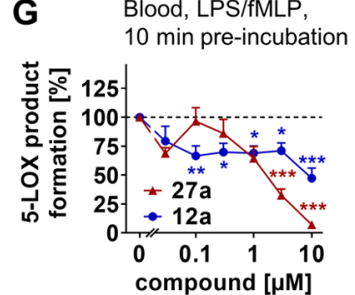

Figure 3. Compound 27a accumulates in innate immune cells and inhibits 5-LOX product formation. (A) Effect of 27a on 5-LOX product

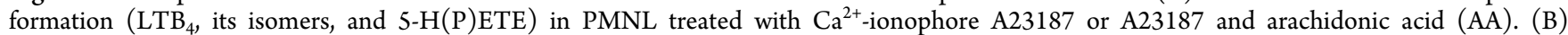
Intracellular uptake of 27a or 12a by PMNL treated with $150 \mathrm{nM}$ of the respective compound for 20 min. Average intracellular concentrations were calculated for spherical PMNL with a diameter of $13 \mu \mathrm{m}$. (C) Effect of 27a or 12a on 5-LOX product formation initiated by A23187 and AA in LPS-prestimulated monocytes. (D, E) Effect of 27a on AA release from Escherichia coli-stimulated macrophages (D) and fMLP-induced Ca ${ }^{2+}$ influx in PMNL (E). (F, G) Effects of 27a or 12a on 5-LOX product formation in human whole blood stimulated with A23187 (F) or LPS and fMLP (G) upon preincubation with the compounds for $10 \mathrm{~min}(\mathrm{~F}, \mathrm{G})$ or $3 \mathrm{~h}(\mathrm{~F})$. Data are expressed as mean \pm SEM (A, C $-\mathrm{G})$ or mean with single values (B) from $n=3$ (A-E, F, left panel) and $n=4$ (F, right panel, G) independent experiments. $*_{p}<0.05, * * p<0.01$, *** $p<0.001 v s$ control (A, C-G); RM one-way ANOVA + Tukey's post hoc test (A, C-G).

Figures 1 and S1 summarize the SARs for 5-LOX inhibition in a network that was calculated based on the structural similarity of the derivatives, with the size of the symbols indicating their potency in cell-free (Figure S1) and cell-based assays (Figure 1).

Mechanism of 5-LOX Inhibition and Binding Mode. Compound 27a inhibited human recombinant 5-LOX independent of the substrate concentration (Figure 2A) in a reversible manner (Figure 2B). Nonspecific inhibition through detergent-sensitive colloidlike aggregates was excluded by supplementing the detergent Triton $\mathrm{X}-100$, which did not substantially impair 5-LOX inhibition by 27a (Figure 2C). Moreover, the concentrations of 27 a that exhibit antioxidative properties exceed those that effectively inhibit 5-LOX, as measured by radical scavenging (Figure 2D).

We have recently shown for 13d that it binds 5-LOX close to Trp102, Trp13, Trp75, and Arg101 at the interface of the catalytic and regulatory C2-like domain. ${ }^{6}$ To investigate whether 27a targets the same site, we monitored the intrinsic Trp fluorescence of human 5-LOX. The spectral center of mass was substantially shifted to a shorter wavelength by both $13 \mathrm{~d}$ and the endogenous vitamin $\mathrm{E}$ metabolite 12a (Figures 2E, S3A, and S3B), which indicates an altered chemical environment of Trp following ligand binding. ${ }^{63}$ This trend was also evident for $27 \mathrm{a}$, but the wavelength shift was less pronounced (Figure 2E). We conclude that the 5-LOX binding pose of 27a is similar but not identical to the $\omega$-carboxylic acids 12a and 13d. Site-directed mutagenesis studies strengthen our hypothesis. The inhibitory activity of $\mathbf{1 3 \mathbf { d }}$ is sensitive to Trp102Ala/ Trp13Ala/Trp75Ala triple mutation and Arg101Asp replacement, ${ }^{6}$ whereas these mutations failed to affect 5-LOX inhibition by 27 a (Figure $2 \mathrm{~F}$ ).

Molecular docking studies confirm results from mutation experiments and point out poses where 13d interacts with $\mathrm{NH}$ of Trp102 (H-bond with phenolic oxygen) and with Arg101 through an ionic interaction involving the $\omega$-carboxylic acid function of 13d (Figure S2A). Binding of $27 \mathrm{~d}$ within the 5-
LOX allosteric site similarly involves an interaction of the phenol function with Trp102. However, at the tail of the side chain, the binding with Arg101 of the less polar allylic diol would be weaker than the one described above for the carboxylic acid group. Thus, the allylic diol exhibits multiple stabilizing interactions with various other amino acids, such as Val110 and Glu134 (Figure S2B). Site-directed mutagenesis studies showed that the 5-LOX binding affinity of 13d depends on interactions with Trp102 and Arg101. ${ }^{6}$ Docking poses for 27a suggest differences in the binding mode compared to the $\delta$-form 27d (Figures $2 \mathrm{G}$ and S2B). Despite the substitution of the chromanol by three methyl groups, the heterocycle of $27 \mathrm{a}$, as for $\mathbf{1 3 d}$ and $\mathbf{2 7 d}$, still lies in the vicinity of Trp102 albeit with a shift downward. Consequently, the phenol function does not interact with Trp102 but it exhibits two hydrogen bonds with Asp170. This result supports the less pronounced wavelength shift observed in the fluorescence emission spectra (Figure 2E). Results from the docking studies tend to demonstrate that interactions of the phenol function are more efficient than the ones from the diol moiety to anchor amplexichromanols $27 \mathbf{a}$ and $\mathbf{2 7} \mathbf{d}$ in a close range of Trp102. Eventually, as highlighted by 5-LOX site-directed mutagenesis experiments (Figure 2F), a direct interaction with $\operatorname{Trp} 102$ is not fully required as long as the ligand strongly interacts with other spatially close amino acid residues, such as Asp170, through hydrogen bonds.

5-LOX Inhibition in Innate Immune Cells and Blood. Compound 27a potently suppressed the biosynthesis of $\mathrm{LTB}_{4}$ and other 5-LOX products (i.e., 5-hydroxyeicosatetraenoic acid (5-HETE), $\mathrm{LTB}_{4}$ isomers) in PMNL (A23187 plus arachidonic acid: $\mathrm{IC}_{50}=0.04 \mu \mathrm{M}$; $\mathrm{A} 23187: \mathrm{IC}_{50}=0.05 \mu \mathrm{M}$ ) (Figure $3 \mathrm{~A})$, with superior potency as compared to the cell-free assay (Table 2). As a reason for this gain in 5-LOX inhibitory activity, we found that 27 a strongly accumulates in PMNL (Figure 3B), as previously described for the endogenous vitamin $\mathrm{E}$ metabolite 12a, which is enriched in immune cells, both in vitro and in the inflamed peritoneal cavity in vivo. ${ }^{6} 5$ - 
A
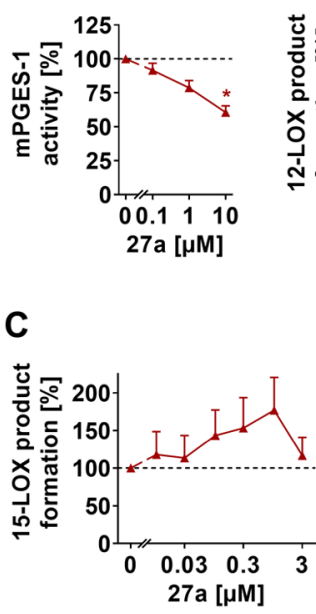

E

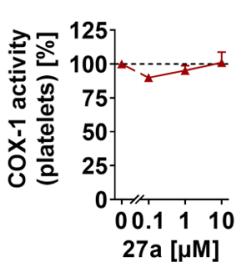

B

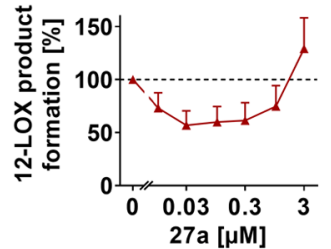

D
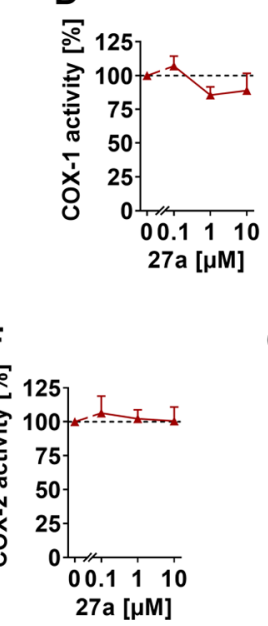

H 27a-treated macrophages, E. coli
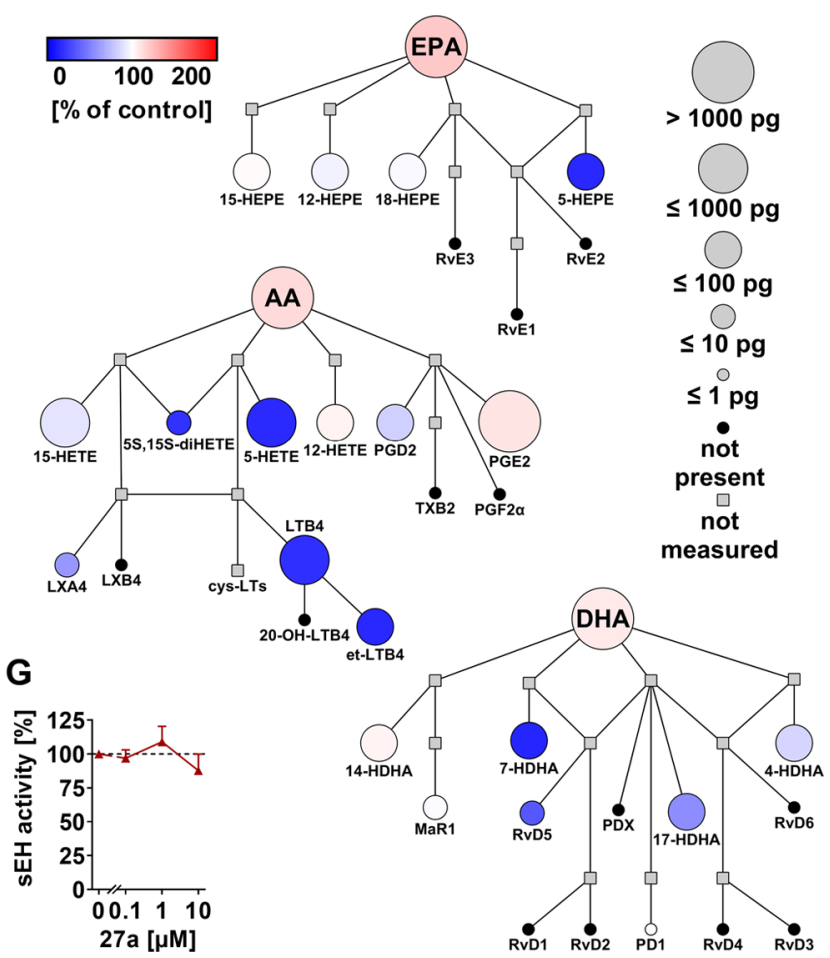

Figure 4. Compound 27a moderately inhibits mPGES-1 within eicosanoid and docosanoid biosyntheses. (A-G) Effect of 27a on mPGES-1 in microsomal preparations of IL-1 $\beta$-treated A549 cells (A), 12-LOX (B), and 15-LOX product formation (C) in PMNL treated with A23187 and AA, isolated ovine COX-1 (D), COX-1-dependent 12-HHT formation in platelets (E), human recombinant COX-2 (F), and human recombinant sEH (G). (H) Quantitative illustration of the lipid mediator network of macrophages (M1) treated with 27a (1 $\mu \mathrm{M})$ and stimulated with pathogenic E. coli as compared to the vehicle control. The node size represents the mean concentration in pg, and the color intensity denotes the fold change for each lipid mediator. AA, arachidonic acid; DHA, docosahexaenoic acid; cys-LTs, cysteinyl-LTs; et-LTB , LTB $_{4}$ isomers; EPA, eicosapentaenoic acid; LX, lipoxine; MaR, maresin; 20-OH- $\mathrm{LTB}_{4}, 20$-hydroxy-LTB $\mathrm{L}_{4} \mathrm{PD}$, protectin; Rv, resolvin; TX, thromboxane. Data are expressed as mean $(\mathrm{H})+\operatorname{SEM}(\mathrm{A}-\mathrm{G})$ from $n=3$ independent experiments. ${ }^{*} p<0.05 v s$ control; RM one-way ANOVA + Tukey's post hoc test.

LOX product formation in monocytes was instead comparably suppressed by $12 \mathrm{a}$ and $27 \mathrm{a}\left(\mathrm{IC}_{50}=0.5-0.6 \mu \mathrm{M}\right)$ (Figure $3 \mathrm{C}$ ), despite the higher potency of $\mathbf{2 7} \mathbf{a}$ to inhibit 5-LOX (Tables 1 and 2).

Acute cytotoxic effects were excluded at effective concentrations of 27a that inhibit 5-LOX $(\leq 1 \mu \mathrm{M})$. Compound 27a impaired neither mitochondrial dehydrogenase activity in peripheral blood mononuclear cells (PBMCs) (Figure S4A), an indicator of cell viability, nor membrane intactness in monocytes within 2 or $24 \mathrm{~h}$ (Figure S4B). At higher concentrations, $27 \mathbf{a}$ induced a rapid release of lactate dehydrogenase $(\mathrm{LDH})$, which was not evident for the endogenous vitamin $\mathrm{E}$ metabolite 12a (Figure S4B).

Our data point toward a direct inhibition of 5-LOX in immune cells. On the one hand, the enzyme was potently inhibited in PMNL by 27a in the presence of exogenous arachidonic acid $\left(\mathrm{IC}_{50}=0.04 \mu \mathrm{M}\right)$, which uncouples LT formation from the $\mathrm{CPLA}_{2}$-triggered release of arachidonic acid and its transfer to 5-LOX by FLAP (Figure 3A). On the other hand, 27a neither reduced the availability of free arachidonic acid in E. coli-stimulated macrophages (Figure 3D) nor influenced intracellular levels of $\mathrm{Ca}^{2+}$, an essential cofactor for $\mathrm{CPLA}_{2} \alpha$ and 5-LOX activation, at submicromolar concentrations $(\leq 1 \mu \mathrm{M})$ (Figure $3 \mathrm{E})$. At higher concentrations of $27 \mathrm{a}(10 \mu \mathrm{M}), \mathrm{Ca}^{2+}$ influx was substantially reduced, as previously reported for $13 \mathbf{d}^{6}$ and other $\omega$-carboxylic acids. ${ }^{64}$

Lipophilic carboxylic acids like 12a are often afflicted with strong plasma protein binding, leading to a loss of inhibitory activity in tissues and blood. ${ }^{65}$ In fact, the dialcohol 27a suppressed 5-LOX product biosynthesis superior to 12a in activated human blood, when treated with either A23187 (Figure $3 \mathrm{~F}$ ) or the physiological stimuli LPS and N-formylmethionyl-leucyl-phenylalanine (fMLP) (Figure 3G). Together, compound 27a targets 5-LOX and potently inhibits LT biosynthesis in innate immune cells and blood, thereby surpassing the endogenous vitamin E metabolite 12a.

mPGES-1 as a Subordinate Target within Lipid Mediator Biosynthesis. LOX, COX, and $\mathrm{CYP}_{450}$ monooxygenases drive the multistep conversion of polyunsaturated fatty acids into lipid mediators and work in concert with further metabolic enzymes to regulate inflammation. ${ }^{13,22,66}$ While some of these enzymes predominantly produce proinflammatory lipid mediators (e.g., mPGES-1), others additionally participate in homeostasis (e.g., COX-1, COX-2) or play important roles in terminating inflammation or triggering resolution (e.g., soluble epoxide hydrolase $(\mathrm{sEH})$, 15-LOX). At micromolar concentrations $(10 \mu \mathrm{M})$, compound 27a decreased mPGES-1 activity (Figure 4A). Other enzymes in lipid mediator biosynthesis were not substantially inhibited: (i) 12-LOX (Figure 4B) and 15-LOX (Figure 4C) in activated human PMNL, (ii) COX-1 as the isolated ovine enzyme (Figure 4D) or within human platelets (Figure 4E), (iii) human recombinant COX-2 (Figure $4 \mathrm{~F}$ ), or (iv) sEH (Figure $4 \mathrm{G}$ ). 15-LOX product formation was even increased by a trend at submicromolar 27a concentrations (Figure 4C). In summary, compound 27 a exhibits superior selectivity to the 


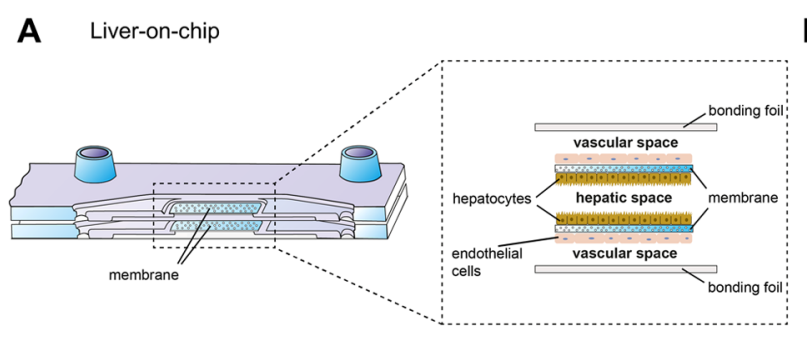

D

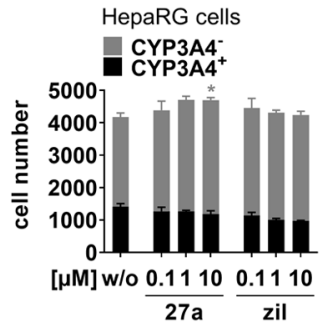

DAPI control

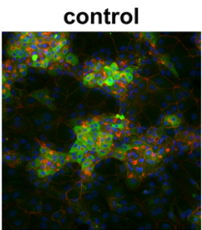

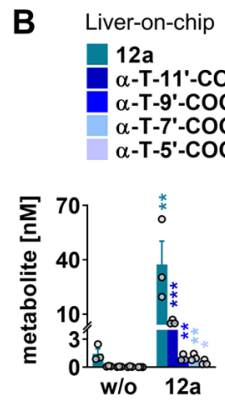
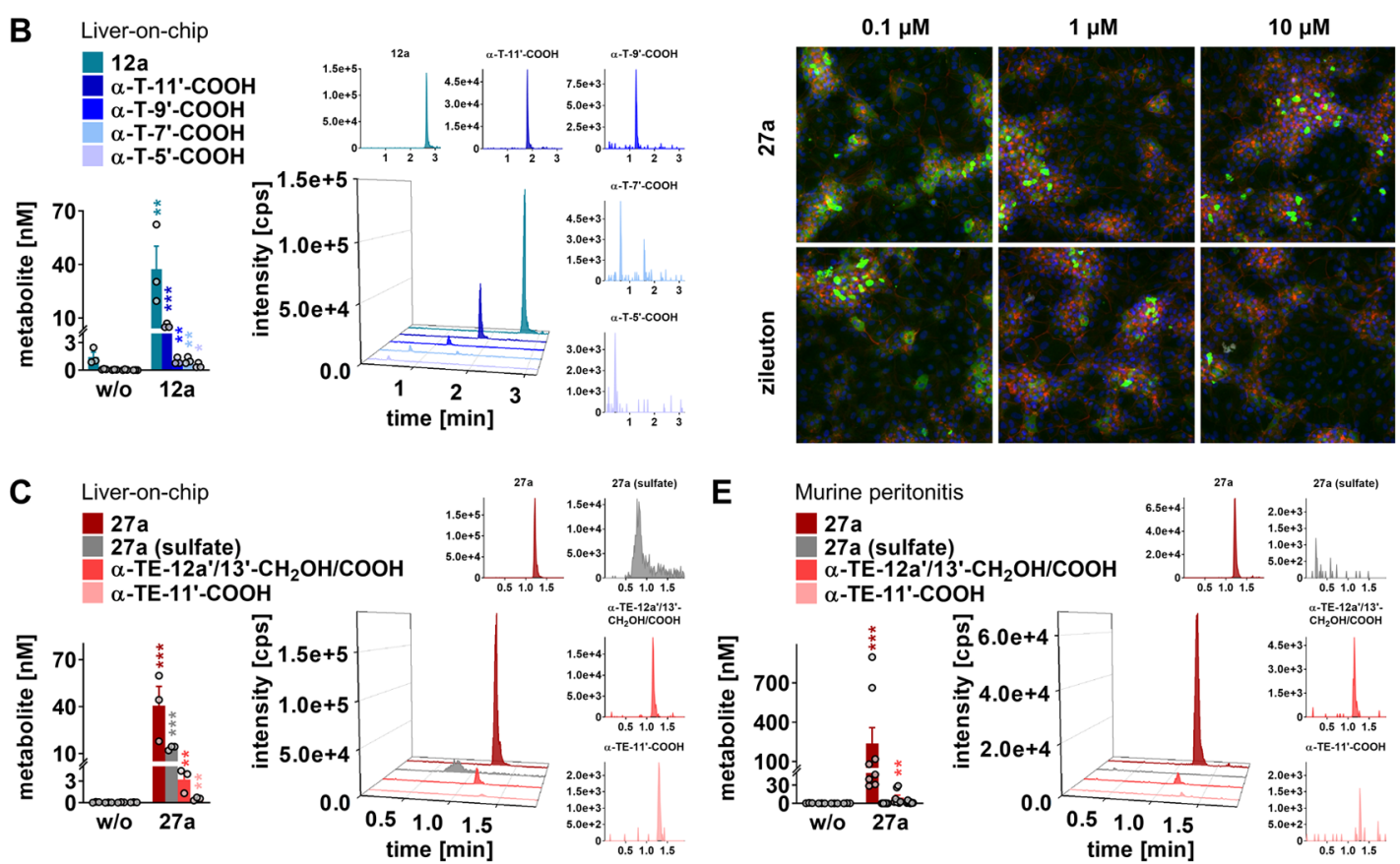

Figure 5. Metabolism of 27a in a human liver-on-chip and in mice. (A) Scheme of the human liver-on-chip model. (B, C) The liver-on-chip was loaded with compound $(1 \mu \mathrm{M})$ and incubated for $48 \mathrm{~h}$. Extracted chromatograms (representative of three independent experiments) and concentrations of 12a and metabolites (B) or 27a and metabolites (C). (D) Effect of 27a and zileuton (zil) on CYP3A4 expression in differentiated HepaRG cells after treatment for $48 \mathrm{~h}$. Fluorescence images (20× magnification) visualize CYP3A4-expressing $\left(\right.$ CYP3A4 $\left.{ }^{+}\right)$and CYP3A4nonexpressing cells $\left(\mathrm{CYP} 3 \mathrm{~A}^{-}\right)$and are representative of nine (w/o) or three independent experiments. (E) Extracted chromatograms (representative of eight mice) and concentrations of $27 \mathbf{a}$ and metabolites in plasma of mice with acute peritonitis 90 min post $27 \mathbf{a}$ administration $(10 \mathrm{mg} / \mathrm{kg}$, p.o.). Data are expressed as mean \pm SEM (D) and single values (B, C, E) from $n=3$ (B, C, D, 27a, and zil, E, w/o), $n=8$ (E, 27a), and $n=9(\mathrm{D}, \mathrm{w} / \mathrm{o})$ independent experiments. ${ }^{*} p<0.05$, ${ }^{*} p<0.01, *^{*} *<0.001$ vs control; two-tailed unpaired $t$-test of log data (B, C, E), ordinary one-way ANOVA + Tukey's post hoc test (D). The nomenclature used for LCMs is explained in Table S2.

endogenous vitamin E metabolite $12 a{ }^{6}$ with 5 - LOX as the primary and mPGES- 1 as the subordinate target.

To investigate the consequences on the lipid mediator network, we stimulated human macrophages (M1 subtype) with pathogenic $E$. coli and performed a comprehensive metabololipidomics analysis. At concentrations that do not effectively inhibit mPGES-1 $(1 \mu \mathrm{M}), 27$ a preferentially suppressed the biosynthesis of 5-LOX-derived products, i.e., $\mathrm{LTB}_{4}$, its isomers, 5-HETE, 5,15-diHETE, 5-hydroxyeicosapentaenoic acid (HEPE), and 7-hydroxydocosahexaenoic acid (HDHA) (Figure 4H). On the other hand, $\mathrm{PGE}_{2}$ levels slightly increased, which we ascribed to the 5-LOX substrate arachidonic acid being channeled into $\mathrm{PGE}_{2}$ biosynthesis. Thus, our data indicate that the impact of $27 \mathbf{a}$ on the lipid mediator profile is mainly determined by 5 -LOX inhibition, as shown for macrophages (Figure $4 \mathrm{H}$ ) and confirmed in monocytes (Figure S5).

Superior Metabolic Stability against Side-Chain Truncation. We studied the hepatic metabolism of 12a and 27a using a human liver-on-chip. ${ }^{6}$ The biochip resembles a liver sinusoid and consists of a hepatic and vascular compartment, which are separated by two porous membranes that serve as cell scaffolds (Figure 5A). For the hepatic compartment, we selected HepaRG cells, which are considered to be the closest to human primary hepatocytes among liver cell lines, and differentiated them into hepatocyte-like and biliary-like cells. The endothelial layer mimics the endothelial lining of the liver sinusoid and consists of human umbilical vein endothelial cells (HUVECs).

The metabolism of $12 \mathrm{a}$ and $27 \mathrm{a}$ substantially differs. While 12a is truncated to metabolites with varying side-chain lengths (Figure 5B), 27a is preferentially conjugated with sulfate or oxidized at $12 \mathrm{a}^{\prime}$ or $13^{\prime}$ to the respective $\omega$-carboxylic acid (Figure 5C). Truncation of the side chain was instead negligible. Despite being a substrate for hepatic $\omega$-oxidation, 27a did not induce $\mathrm{CYP}_{450}$ enzyme expression in HepaRG cells, as exemplarily studied for CYP3A4 (Figure 5D).

Next, we investigated the metabolism of $27 \mathbf{a}$ after oral administration in mice. Compound 27a was taken up within 1 $\mathrm{h}$, reaching plasma concentrations $(0.03-0.9 \mu \mathrm{M})$ that effectively inhibit 5-LOX in vitro (Figure $5 \mathrm{E}$ ). We confirmed that the unsaturated chain of $27 \mathbf{a}$ is resistant to degradation 
A

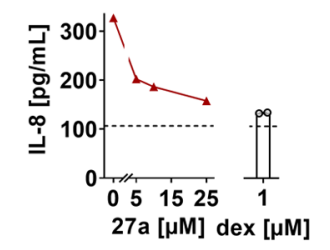

B

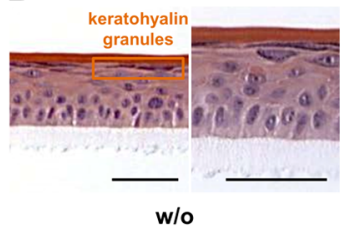

D

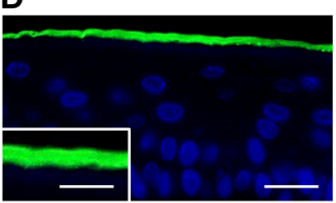

w/o
C

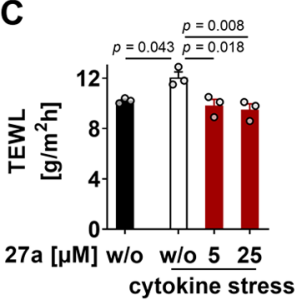

E

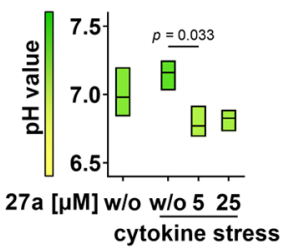

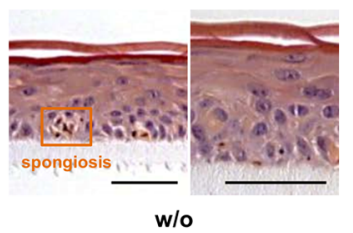
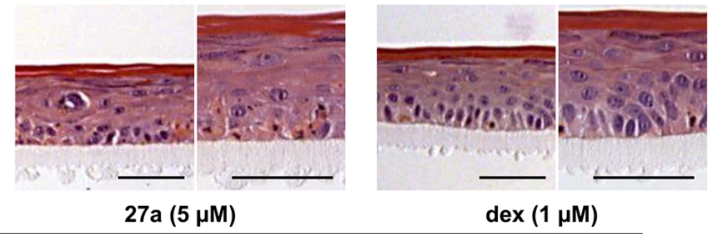

cytokine stress

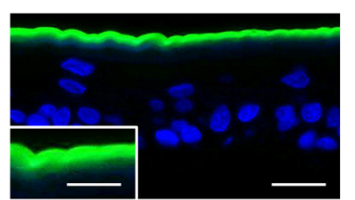

w/o

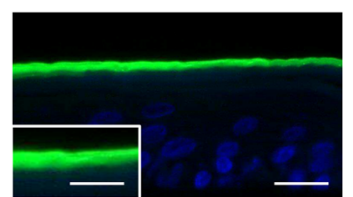

$27 \mathrm{a}(5 \mu \mathrm{M})$

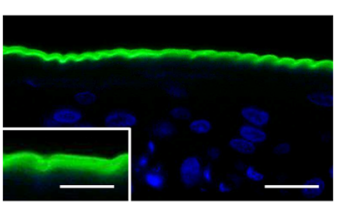

$27 a(25 \mu M)$

cytokine stress

Figure 6. Compound 27a relieves inflammation in reconstructed human epidermis (RHE). RHE exposed to 27a or dexamethasone (dex) was treated with a cytokine cocktail for 4 days to trigger the inflammatory reaction. (A) Concentration of IL- 8 in the growth medium. The dotted line indicates basal levels without cytokine stress. (B) Morphological changes visualized by hematoxylin and eosin staining (scale bar is $50 \mu$ m; representative of three independent experiments). (C) Transepidermal water loss (TEWL) at the RHE surface. (D) Impermeability of the stratum corneum. The stratum corneum of cytokine-stressed RHE becomes permeable for Lucifer yellow (green) that diffuses into the viable cell layers, as shown in the insets in higher magnification (scale bar for the outer box is $20 \mu \mathrm{m}$, and scale bar for the inset is $10 \mu \mathrm{m}$; representative of three independent experiments). Nuclei were stained with $4^{\prime}, 6^{\prime}$-diamidino-2-phenylindole (DAPI, blue). (E) pH value at the RHE surface. Data are expressed as mean $\pm \operatorname{SEM}(\mathrm{A}, 27 \mathrm{a})$ with single values $(\mathrm{A}$, dex, $\mathrm{C})$ or mean + floating bars from minimum to maximum values $(\mathrm{E})$ from $n=2$ (A) and $n=3(\mathrm{C}, \mathrm{E})$ independent experiments. Ordinary one-way ANOVA + Tukey's post hoc test.

but did not detect sulfate conjugates (Figure 5E). We conclude that $27 \mathrm{a}$ is less susceptible to side-chain degradation than the endogenous metabolite $12 \mathrm{a}$ and speculate about speciesspecific differences in 27 a sulfation between mice and humans.

Improved Epidermal Homeostasis in Experimental Atopic Dermatitis. LT levels are substantially increased in relapsing inflammatory skin lesions in atopic dermatitis, as are other lipid mediators and cytokines. ${ }^{67}$ To study the effect of $27 \mathbf{a}$ on the inflammatory processes leading to skin dysfunction, we used reconstructed human epidermis (RHE) and induced cytokine stress. Interleukin (IL)-8, an indicator of the severity of inflammation in atopic dermatitis, ${ }^{68}$ was upregulated (Figure $6 \mathrm{~A}$ ), as was thymic stromal lymphopoietin (TSLP) (Figure $\mathrm{S6A}$ ), which is an IL-7-like cytokine that propagates skin lesions by mediating the recruitment and polarization of Th2type $\mathrm{CD}^{+}$cells. $^{69}$ Morphological and functional changes in the epidermal structure are characterized by spongiosis and the loss of keratohyalin granules (Figures 6B and S6B). The latter is associated with a diminished expression of filaggrin, one of the crucial proteins to maintain skin barrier function. ${ }^{70}$ Along these lines, cytokine stress triggers transepidermal water loss (Figure 6C) and allows the fluorescent dye Lucifer yellow to pass the stratum corneum (Figures 6D and S6C).

Moreover, the $\mathrm{pH}$ increased by trend (Figure $6 \mathrm{E}$ ), which is believed to hamper skin barrier homeostasis, thereby interfering with the innate immune defense in atopic dermatitis. $^{71}$ Dexamethasone, used as a control, suppressed these cytokine-induced responses, as expected.

Compound 27a reduced IL-8 levels (Figure 6A), attenuated the epidermal disorganization induced by cytokine treatment
(Figures 6B and S6B), and substantially improved skin barrier functions (Figure 6C, D and S6C). The $\mathrm{pH}$ was decreased even below the basal level (Figure 6E). Thus, compound 27a limits the inflammatory reaction and supports epidermal homeostasis in experimental atopic dermatitis. On the other hand, 27a did not influence TSLP expression in the RHE (Figure S6A), rather excluding a major impact on Th2mediated tissue damage. Cytotoxic effects of 27a on human keratinocytes were excluded under our experimental conditions (Figure S6D).

Attenuated Inflammation in Murine Peritonitis. The anti-inflammatory efficacy of $\mathbf{2 7 a}$ was investigated for zymosan-induced murine peritonitis in vivo, which represents a model of acute inflammation that relies on LTs and other lipid mediators (Figure $7 \mathrm{~A}) .^{72}$ During the onset of inflammation, zymosan activates resident peritoneal macrophages that produce $\mathrm{LTC}_{4}$. This cysteinyl-LT increases vasopermeability in postcapillary venules. Compound 27a, given i.p., strongly decreased $\mathrm{LTC}_{4}$ levels in the exudate (Figure $7 \mathrm{~B}$ ) and consequently reduced vascular permeability (Figure $7 \mathrm{C}$ ). The progressive phase of inflammation is instead dominated by infiltrated neutrophils that generate the potent chemoattractant $\mathrm{LTB}_{4}$. Compound 27a was also active at this stage and substantially lowered $\mathrm{LTB}_{4}$ levels, both in the exudate (Figure 7D) and by trend in plasma (Figure S7A). The influx of cells into the peritoneal cavity (Figure $7 \mathrm{E}$ ), which is dominated by neutrophil infiltration, ${ }^{72}$ was accordingly reduced.

While oral administration of 27 a yielded plasma concentrations between 0.02 and $2.58 \mu \mathrm{M}$ (Figure 7F), concen- 
A

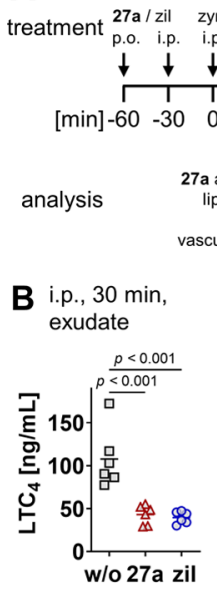

E i.p., $4 \mathrm{~h}$,

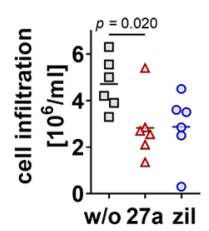

C i.p., $30 \mathrm{~min}$

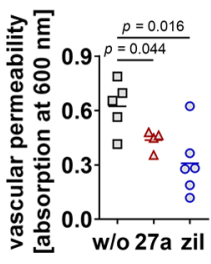

F p.o., $30 \mathrm{~min}$, plasma

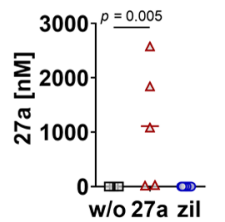

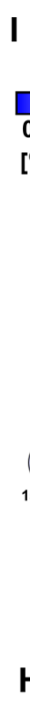
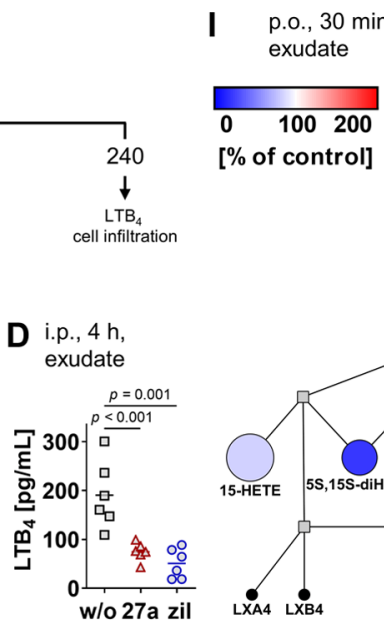

$\mathbf{G} \begin{aligned} & \text { p.o., } 30 \mathrm{~min} \\ & \text { exudate }\end{aligned}$ exudate

Figure 7. Compound 27a inhibits 5-LOX product formation and limits inflammation in murine peritonitis. (A) Time scale for zymosan-induced murine peritonitis. (A-I) Mice received 27a (B-E, I: $10 \mathrm{mg} / \mathrm{kg} ; \mathrm{F}, \mathrm{G}: 30 \mathrm{mg} / \mathrm{kg}$; H: $3 \mathrm{mg} / \mathrm{kg}$; B-E: i.p.; F-I: p.o.) or zileuton (zil; B-E: $10 \mathrm{mg} /$ kg; F, G: $30 \mathrm{mg} / \mathrm{kg}$; H: $3 \mathrm{mg} / \mathrm{kg}$; B-E: i.p.; F-H: p.o.) and were killed $30 \mathrm{~min}$ (B, C, F-I) or 4 h (D, E) post zymosan injection. (B, H) LTC levels in the exudate analyzed by ELISA. (C) Vascular permeability. (D) LTB $_{4}$ levels in the exudate analyzed by ELISA. (E) Immune cell infiltration into the peritoneal cavity. (F, G) Concentration of $27 \mathbf{a}$ in the plasma (F) and exudate (G). (I) Quantitative illustration of the lipid mediator network in the peritoneal exudate from mice given 27a as compared to the vehicle. The node size represents the mean concentration in pg, and the color intensity denotes the fold change for each lipid mediator. ${ }^{\circ} \mathrm{LTC}_{4}$ was analyzed by ELISA, and all other lipid mediators and fatty acids were analyzed by UPLC-MS/MS. AA, arachidonic acid; DHA, docosahexaenoic acid; EPA, eicosapentaenoic acid; LX, lipoxin; MaR, maresin; 20-OH-LTB, 20 -hydroxy-LTB $\mathrm{LPD}_{4}$, protectin; Rv, resolvin; t-LTB, $\mathrm{LTB}_{4}$ isomer; TX, thromboxane. Data are expressed as mean (I) with single values $(\mathrm{B}-\mathrm{H})$ from $n=3(\mathrm{~F}, \mathrm{w} / \mathrm{o}), n=4$ (C, 27a), $n=5$ (C, w/o, F, 27a), $n=6$ (B, C, zil, D, E), $n=8(\mathrm{H}, \mathrm{w} / \mathrm{o}), n=9(\mathrm{G}, \mathrm{w} / \mathrm{o}, \mathrm{H}, \mathrm{zil}, \mathrm{I}, \mathrm{w} / \mathrm{o})$, and $n=10$ (F, zil, G, 27a and zil, H, 27a, I, 27a) mice. Two-tailed unpaired $t$-test of $\log$ data $(\mathrm{B}-\mathrm{H})$.

trations of $27 \mathbf{a}$ in the peritoneal exudate were considerably lower $(0.5-4 \mathrm{nM})$ (Figure $7 \mathrm{G}$ ) but likely still in a range that inhibits 5-LOX, given the strong intracellular accumulation of 27a in immune cells in vitro (Figure 3B). Cysteinyl-LTs were decreased to a basal level by $27 \mathrm{a}$ at a dose of $3 \mathrm{mg} / \mathrm{kg}$ (Figure $7 \mathrm{H}$ ). The clinically used 5-LOX inhibitor zileuton (at $3 \mathrm{mg} /$ $\mathrm{kg}$ ) did not evoke a stronger effect. Metabololipidomics profiling showed a preferential drop of arachidonic acidderived 5-LOX products in exudates from 27a-treated mice and a moderate reduction of various other LOX-derived metabolites (Figure 7I). The latter likely depends on the reduced availability of free polyunsaturated fatty acids. Conclusively, 27a is an orally active 5-LOX inhibitor that potently suppresses LT formation and associated peritoneal inflammation in vivo.

We have recently shown that the endogenous metabolite 12a augments the systemic concentration of resolvin E3, a specialized proresolving lipid mediator that actively terminates the resolution of inflammation. ${ }^{6,22}$ Although our study focused on acute inflammation and has only limited predictive power for the resolution phase, we found resolvin E3 levels already being moderately increased by $27 \mathrm{a}$ at $30 \mathrm{~min}$ post zymosan injection in individual mice (Figure S7B). It is tempting to speculate that 27 a shares the putative proresolving potential of the endogenous lead compound.
Diminished Airway Hyperreactivity in Experimental Asthma. Since LTs play a pivotal role in the pathogenesis of asthma by propagating lung inflammation, immune cell infiltration, and bronchoconstriction, ${ }^{15,73}$ we investigated the effects of 27a in an experimental model of asthma. Mice were treated with 27 a p.o. $60 \mathrm{~min}$ before being sensitized with ovalbumin on days 0 and 7 and monitored up to 21 days (Figure 8A). Systemic concentrations of 27 a peaked at the days after administration (days 1 and 8 ) and then rapidly declined again in the plasma and lung (Figure 8B). Gavage of 27a lowered lung levels of $\mathrm{LTB}_{4}$ and its isomers (Figure 8C), blocked ovalbumin-induced bronchial hyperreactivity to carbachol (Figure 8D), and fully restored the adrenergic bronchial relaxation induced by salbutamol (Figure $8 \mathrm{E}$ ). Together, compound $\mathbf{2 7 a}$ is orally available and distributed to the lung, thereby effectively suppressing pulmonary LT levels and asthmatic airway contraction.

\section{DISCUSSION AND CONCLUSIONS}

Inspired by the endogenous vitamin $\mathrm{E}$ metabolite 12a, which may mediate immunomodulatory effects of vitamin $\mathrm{E},{ }^{6,7}$ we designed a novel class of potent 5-LOX inhibitors that limit inflammation. We previously explored $13^{\prime}$-garcinamides, which impress through their potent 5-LOX inhibitory activity, ${ }^{42}$ but were substantially less active in innate immune cells. Extended SAR studies revealed oxidative $\omega$-modifications of the side 
A

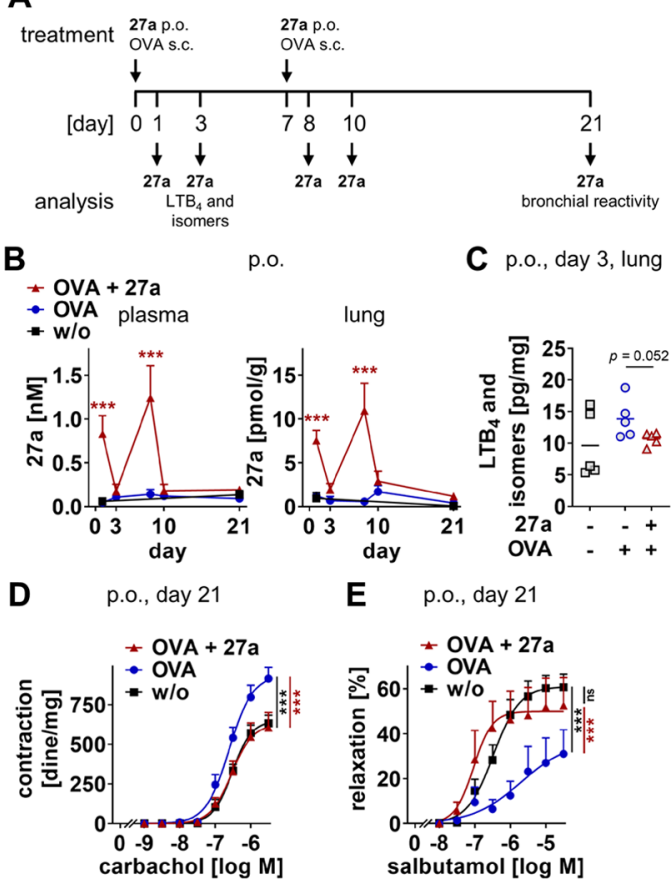

Figure 8. Compound 27a suppresses bronchial hyperreactivity and pulmonary LT formation in mice sensitized to ovalbumin. (A) Time scale for the experimental asthma model. (B-E) Compound 27a (10 $\mathrm{mg} / \mathrm{kg}$ ) was p.o. administered to mice prior to injection of ovalbumin (OVA) on days 0 and 7. (B) Concentrations of 27a in plasma (nM) and lung (pmol/g lung tissue). (C) Pulmonary levels of $\mathrm{LTB}_{4}$ and its isomers on day 3 in $\mathrm{pg} / \mathrm{mg}$ lung tissue. (D, E) Bronchial reactivity to carbachol (D) or salbutamol (E) on day 21. Data are expressed as mean with single values $(\mathrm{C})$ or mean $\pm \operatorname{SEM}(\mathrm{B}, \mathrm{D}, \mathrm{E})$ from $n=5$ (B, days $1-10, \mathrm{C}), n=6$ (B, day 21), $n=7$ (E, OVA, OVA + 27a), $n=8$ $(\mathrm{D}$, OVA $+27 \mathrm{a}), n=11(\mathrm{D}, \mathrm{OVA}, \mathrm{E}$, control), and $n=12$ (D, control) mice. ns, not significant; $* * * p<0.001 v s$ control or as indicated; two-tailed unpaired $t$-test of log data (C), two-way ANOVA + Bonferroni's post hoc test (B, D, E).

chain as a superior strategy toward potent 5-LOX inhibitors that maintain their privileged access to innate immune cells. These two criteria were best realized by the $\mathrm{C} 12 \mathrm{a}^{\prime}-/ \mathrm{C} 13^{\prime}$ dihydroxylated $\alpha$-tocotrienol 27a, which inhibits 5-LOX in a substrate-independent manner at concentrations that do not allow efficient radical scavenging. Compound 27 a seems to bind 5-LOX slightly displaced from 12a and 13d in the vicinity of Trp102, as suggested by molecular docking studies, Trp fluorescence spectroscopy, and site-directed mutagenesis. In contrast to $\omega$-oxidation, the chromanol core and the unsaturated side chain of $\mathbf{2 7}$ a offer little space for structural optimization. Although we identified modifications that turn $27 \mathbf{a}$ in an even more potent 5-LOX inhibitor, the pharmacologically relevant inhibition of 5-LOX product formation in PMNL was not enhanced.

Compound 27a strongly accumulates in PMNL, reaching a comparable intracellular concentration as 12a. Accordingly, 27a superiorly inhibits 5-LOX product biosynthesis in activated PMNL and human blood but not in monocytes.

These cell-type-specific differences are in favor of our hypothesis that LCMs are efficiently taken up by cells through specific transport systems. Within cellular lipid mediator biosynthesis, 5-LOX is the direct and primary target of $27 \mathrm{a}$, and its inhibition shapes the lipid mediator profile of activated human macrophages and monocytes. Although $27 \mathbf{a}$ is considerably more selective than $12 \mathrm{a},{ }^{6}$ both compounds additionally inhibit mPGES-1 at high concentrations, which might be beneficial to damp the redirection of the 5-LOX substrate arachidonic acid toward proinflammatory $\mathrm{PGE}_{2}$ biosynthesis.

Compound $27 \mathbf{a}$ is orally available and reaches plasma and lung concentrations that effectively inhibit 5-LOX in vitro. Rapid clearance of 27a from the plasma is accompanied by substantial retardation in tissues, including inflamed lungs. Along these lines, 27a is more stable against side-chain truncation than 12a. While we did not detect 27a metabolites in mice in vivo (within $90 \mathrm{~min}$ ), 27a was efficiently sulfated or $\omega$-oxidized to a carboxylic acid in a human liver-on-chip (within $48 \mathrm{~h}$ ), which might be related to the kinetics or species-specific differences in $\mathbf{2 7} \mathbf{a}$ metabolism. It is tempting to speculate that both metabolites of $27 \mathrm{a}$, the sulfate and $\omega$ carboxylic acid, possess 5-LOX inhibitory activity or, in the case of the 27a sulfate, might be hydrolyzed to the active compound in tissues that highly express sulfatases, such as the lung and liver. ${ }^{74}$

We demonstrate anti-inflammatory efficacy of $\mathbf{2 7} \mathbf{a}$ in murine models of peritonitis and asthma in vivo, for both i.p. and p.o. administration, and in experimental atopic dermatitis in vitro using RHE. Compound 27a effectively suppresses LT levels along with LT-driven hallmarks of inflammation, i.e., immune cell infiltration, vasopermeability, and bronchial hyperreactivity.

In conclusion, we here present compound $27 \mathrm{a}$, a potent and orally active LCM-inspired 5-LOX inhibitor that shares the favorable pharmacological profile of the endogenous vitamin $\mathrm{E}$ metabolite 12a but is even more potent, selective, and metabolically stable, thereby allowing an efficient suppression of inflammation in vitro and in vivo. Whether 27a shares the proposed proresolving activities of 12a needs further investigation.

\section{EXPERIMENTAL SECTION}

Isolation and Semisynthesis of Vitamin E Derivatives. ${ }^{1} \mathrm{H}$ and ${ }^{13} \mathrm{C}$ NMR along with 2D NMR data were obtained on a Bruker Avance DRX $500 \mathrm{MHz}$ spectrometer $(500$ and $125 \mathrm{MHz}$, respectively; BRUKER, Bremen, Germany) or a JEOL JNM-ECZS $400 \mathrm{MHz}$ spectrometer (400 and $100 \mathrm{MHz}$, respectively; JEOL Ltd., Akishima, Tokyo, Japan) in deuterated chloroform, methanol, or acetone and calibrated using the residual undeuterated solvent resonance as an internal reference. IR spectra were recorded on a Thermo Scientific Nicolet iS5 FT-IR spectrometer (Thermo Scientific). Mass spectrometry analyses were performed on a JEOL JMS-700 (JEOL Ltd.) double-focusing mass spectrometer with reversed geometry, equipped with a pneumatically assisted EI or FAB source and on a BRUKER ESQUIRE 3000+ spectrometer (BRUKER) for ESI analyses in both positive and negative modes. Chromatographic analysis was performed on a Prominence-i LC2030C (Shimadzu, Noisiel, France) equipped with a refrigerated autosampler and a column oven. The HPLC system was coupled to an evaporative light-scattering detector (ELSD SEDEX $90 \mathrm{LT}$, SEDERE). Then, $5 \mu \mathrm{L}$ samples refrigerated at $10{ }^{\circ} \mathrm{C}$ were injected onto a Phenomenex Luna C18 column $(150 \mathrm{~mm} \times 4.6 \mathrm{~mm}, 5 \mu \mathrm{m})$ heated at $20^{\circ} \mathrm{C}$. A gradient of water with $0.1 \%$ formic acid (A) and acetonitrile with $0.1 \%$ formic acid (B) was applied $(65 \%$ B for $1 \mathrm{~min}$, $65-77 \%$ B within $4 \mathrm{~min}, 77 \%$ B for $8 \mathrm{~min}, 77-100 \%$ B within $5 \mathrm{~min}$, $100 \% \mathrm{~B}$ for $6 \mathrm{~min}$ ) at a flow rate of $1 \mathrm{~mL} / \mathrm{min}$. ELSD experiments were performed at $50{ }^{\circ} \mathrm{C}$, and nitrogen was used as the nebulization gas (3.5 bar). Data were acquired and processed with LabSolutions Software (Shimadzu, Noisiel, France). Spectra for selected vitamin E analogues (13a, 13d, 27a, 27d) are shown in Figures S57-S60. Purity determined using ELSD experiments was $\geq 95 \%$. Chromatographic 
separations, such as flash chromatography, were performed on IntelliFlash 310 (Analogix) using a silica gel column Chromabond flash RS column (Macherey-Nagel). Reactions under microwave irradiations were performed using an Anton Paar Monowave 300 microwave reactor (Anton Paar). All reactions under microwave irradiations were performed using the stirring option in borosilicate glass vials of 10 or $30 \mathrm{~mL}$ (G10 or G30) sealed with PTFE-coated silicone septa (at the end of the irradiation, cooling of reaction mixtures was realized by compressed air). The microwave instrument consists of a continuous focused microwave power output from 0 to $600 \mathrm{~W}$. The target temperature was reached with a ramp of $3 \mathrm{~min}$, and the chosen microwave power was maintained at a constant to hold the mixture at this temperature. The reaction temperature was monitored using a calibrated infrared sensor, and the reaction time included the ramp period. The microwave irradiation parameters (power, temperature, and time) were monitored by the Monowave software package.

(R)-2-((3E,7E, 11Z)-13-Hydroxy-4,8,12-trimethyltrideca-3,7,11trien-1-yl)-2,8-dimethylchroman-6-yl-4-methylbenzenesulfonate (49). To a solution of $\delta$-(Z)-deoxyamplexichromanol $10 \mathrm{e}(152 \mathrm{mg}$, $0.36 \mathrm{mmol}, 1$ equiv) in dichloromethane $(5 \mathrm{~mL})$ were added 4toluenesulfonyl chloride ( $75 \mathrm{mg}, 0.39 \mathrm{mmol}, 1.1$ equiv) and triethylamine ( $60 \mu \mathrm{L}, 0.43 \mathrm{mmol}, 1.2$ equiv). The reaction mixture was stirred at room temperature for $2.5 \mathrm{~h}$. Then, the reaction was quenched with a saturated aqueous solution of sodium bicarbonate. The resulting mixture was extracted three times with diethyl ether. The combined organic layers were washed with water and brine, dried over anhydrous sodium sulfate, filtered, and concentrated under reduced pressure. The residue was purified by column chromatography on silica gel eluted with a petroleum ether/diethyl ether mixture 6:4 to afford the desired product 49 with $72 \%$ yield. Brown oil; $R_{f}=$ 0.62 (petroleum ether/acetone/dichloromethane 7:2:1). ${ }^{1} \mathrm{H}$ NMR $\left(400 \mathrm{MHz}, \mathrm{CDCl}_{3}\right) \delta_{\mathrm{H}} 7.71(\mathrm{~d}, J=8.4 \mathrm{~Hz}, 2 \mathrm{H}), 7.30(\mathrm{~d}, J=7.9 \mathrm{~Hz}$, $2 \mathrm{H}), 6.55(\mathrm{~d}, J=2.6 \mathrm{~Hz}, 1 \mathrm{H}), 6.53(\mathrm{~d}, J=2.4 \mathrm{~Hz}, 1 \mathrm{H}), 5.26(\mathrm{t}, J=7.4$ $\mathrm{Hz}, 1 \mathrm{H}), 5.14-5.07(\mathrm{~m}, 2 \mathrm{H}), 4.09(\mathrm{~s}, 2 \mathrm{H}), 2.67-2.63(\mathrm{~m}, 2 \mathrm{H}), 2.44$ (s, 3H), 2.15-2.04 (m, 6H), $2.05(\mathrm{~s}, 3 \mathrm{H}), 1.99-1.95(\mathrm{~m}, 4 \mathrm{H}), 1.81-$ $1.69(\mathrm{~m}, 2 \mathrm{H}), 1.78(\mathrm{~s}, 3 \mathrm{H}), 1.65-1.50(\mathrm{~m}, 2 \mathrm{H}), 1.58(\mathrm{~s}, 6 \mathrm{H}), 1.25(\mathrm{~s}$, $3 \mathrm{H}) .{ }^{13} \mathrm{C}$ NMR $\left(100 \mathrm{MHz}, \mathrm{CDCl}_{3}\right) \delta_{\mathrm{C}} 150.7,145.0,141.5,135.3$, 134.6, 134.5, 132.9, 129.6 (2C), 128.6 (2C), 128.2, 127.5, 124.8, $124.2,121.9,121.2,120.2,76.2,61.6,39.9$ (2C), 39.7, 30.9, 26.6, 26.3, 24.1, 22.4, 22.2, 21.8, 21.3, 16.1 (2C), 15.9.

(2Z,6E, 1OE)-13-((R)-2,8-Dimethyl-6-(tosyloxy)chroman-2-yl)2,6,10-trimethyltrideca-2,6,10-trienoic Acid (50). To a solution of 49 (152 mg, $0.27 \mathrm{mmol}, 1$ equiv) in a mixture of $1: 9$ dimethyl sulfoxide/dichloromethane $(5 \mathrm{~mL})$ was added 2-iodoxybenzoic acid ( $280 \mathrm{mg}, 0.54 \mathrm{mmol}, 2$ equiv). The reaction mixture was stirred at room temperature for $12 \mathrm{~h}$. Then, the reaction was quenched with a saturated aqueous solution of sodium bicarbonate. The resulting mixture was extracted three times with dichloromethane. The combined organic layers were washed with water and brine, dried over anhydrous sodium sulfate, filtered, and concentrated under reduced pressure. The crude aldehyde was used for the next step without further purification. To a solution of aldehyde $(145 \mathrm{mg}, 0.26$ mmol, 1 equiv) in 1,4-dioxane $(5 \mathrm{~mL})$ at $0{ }^{\circ} \mathrm{C}$ were added sulfamic acid (40 mg, $0.42 \mathrm{mmol}, 1.6$ equiv), 2-methyl-2-butene $(1.7 \mathrm{~mL}, 13$ $\mathrm{mmol}, 50$ equiv), and a solution of sodium chlorite $(33 \mathrm{mg}, 0.36$ mmol, 1.4 equiv) in water $(1.8 \mathrm{~mL})$. The reaction mixture was stirred at $0{ }^{\circ} \mathrm{C}$ for $2 \mathrm{~h}$. Then, the reaction was quenched with sodium sulfite and diluted with water. The resulting mixture was extracted three times with diethyl ether. The combined organic layers were washed with water and brine, dried over anhydrous sodium sulfate, filtered, and concentrated under reduced pressure. The residue was purified by column chromatography on silica gel using a 7:3 mixture of petroleum ether/diethyl ether as the eluent to afford the expected product $\mathbf{5 0}$ with $75 \%$ yield over the two-step oxidation. Brown oil; $R_{f}=0.45$ (petroleum ether/ethyl acetate 75:25). ${ }^{1} \mathrm{H} \mathrm{NMR}\left(400 \mathrm{MHz}, \mathrm{CDCl}_{3}\right.$ ) $\delta_{\mathrm{H}} 7.72(\mathrm{~d}, J=8.4 \mathrm{~Hz}, 2 \mathrm{H}), 7.30(\mathrm{~d}, J=8.0 \mathrm{~Hz}, 2 \mathrm{H}), 6.55(\mathrm{~d}, J=2.6$ $\mathrm{Hz}, 1 \mathrm{H}), 6.52(\mathrm{~d}, J=2.8 \mathrm{~Hz}, 1 \mathrm{H}), 6.05(\mathrm{td}, J=1.4,7.9 \mathrm{~Hz}, 1 \mathrm{H})$, $5.13-5.10(\mathrm{~m}, 2 \mathrm{H}), 2.67-2.58(\mathrm{~m}, 4 \mathrm{H}), 2.45(\mathrm{~s}, 3 \mathrm{H}), 2.12-2.04(\mathrm{~m}$, $6 \mathrm{H}), 2.05(\mathrm{~s}, 3 \mathrm{H}), 1.98-1.94(\mathrm{~m}, 2 \mathrm{H}), 1.90(\mathrm{~s}, 3 \mathrm{H}), 1.83-1.69(\mathrm{~m}$, $2 \mathrm{H}), 1.64-1.50(\mathrm{~m}, 2 \mathrm{H}), 1.58(\mathrm{~s}, 6 \mathrm{H}), 1.25(\mathrm{~s}, 3 \mathrm{H}) .{ }^{13} \mathrm{C}$ NMR $(100$
$\left.\mathrm{MHz}, \mathrm{CDCl}_{3}\right) \delta_{\mathrm{C}} 171.1,150.8,145.1,141.5,135.4,134.8(2 \mathrm{C}), 132.9$, 129.7 (2C), 128.7 (2C), 127.6, 126.3, 124.5, 124.2, 122.0, 121.2, $120.3,76.3,39.9,39.8,39.4,31.0,26.7,26.4,24.2,22.4,22.2,21.9$, $16.2,16.1,16.0,13.8$. IR (ATR) $\nu_{\max } 2923,2852,1686,1473,1454$, $1372,1093,984 \mathrm{~cm}^{-1}$. MS (EI) $\mathrm{m} / z$ calcd for $\mathrm{C}_{34} \mathrm{H}_{44} \mathrm{O}_{6} \mathrm{~S}\left[\mathrm{M}^{+\bullet}\right]$ 580.3 , found 580.2 .

(2Z,6E, 10E)-13-((R)-6-Hydroxy-2,8-dimethylchroman-2-yl)2,6,10-trimethyltrideca-2,6,10-trienoic Acid (13e). To a solution of 50 (141 mg, $0.24 \mathrm{mmol}, 1$ equiv) in methanol $(8 \mathrm{~mL})$ was added sodium hydroxide $(16 \mathrm{mmol}, 640 \mathrm{mg})$. The mixture was stirred at 70 ${ }^{\circ} \mathrm{C}$ for $3 \mathrm{~h}$. Then, the reaction was quenched with an aqueous solution of hydrochloric acid $(1 \mathrm{M})$. The resulting mixture was extracted three times with dichloromethane. The combined organic layers were washed with water and brine, dried over anhydrous sodium sulfate, filtered, and concentrated under reduced pressure. The residue was purified by column chromatography eluted with a petroleum ether/ acetone mixture, 8:2, to afford the desired product $13 \mathrm{e}$ with $95 \%$ yield. Pale-yellow oil; $R_{f}=0.29$ (petroleum ether/acetone 8:2). ${ }^{1} \mathrm{H}$ $\operatorname{NMR}\left(400 \mathrm{MHz}, \mathrm{CDCl}_{3}\right) \delta_{\mathrm{H}} 6.47(\mathrm{~d}, J=3.5 \mathrm{~Hz}, 1 \mathrm{H}), 6.38(\mathrm{~d}, J=2.8$ $\mathrm{Hz}, 1 \mathrm{H}), 6.24(\mathrm{bs}, 1 \mathrm{H}), 6.06(\mathrm{td}, J=1.4,7.2 \mathrm{~Hz}, 1 \mathrm{H}), 5.14-5.09(\mathrm{~m}$, $2 \mathrm{H}), 2.69(\mathrm{t}, J=6.8 \mathrm{~Hz}, 2 \mathrm{H}), 2.60(\mathrm{dd}, J=7.3,13.7 \mathrm{~Hz}, 2 \mathrm{H}), 2.19-$ $2.16(\mathrm{~m}, 2 \mathrm{H}), 2.13-2.10(\mathrm{~m}, 2 \mathrm{H}), 2.12(\mathrm{~s}, 3 \mathrm{H}), 2.09-2.04(\mathrm{~m}, 6 \mathrm{H})$, $1.98-1.95(\mathrm{~m}, 2 \mathrm{H}), 1.90(\mathrm{~s}, 3 \mathrm{H}), 1.83-1.71(\mathrm{~m}, 2 \mathrm{H}), 1.67-1.49(\mathrm{~m}$, $2 \mathrm{H}), 1.58(\mathrm{~s}, 3 \mathrm{H}), 1.57(\mathrm{~s}, 3 \mathrm{H}), 1.26(\mathrm{~s}, 3 \mathrm{H}) .{ }^{13} \mathrm{C}$ NMR $(100 \mathrm{MHz}$, $\left.\mathrm{CDCl}_{3}\right) \delta_{\mathrm{C}} 172.3,147.8,146.4,146.1,135.2,134.2,127.5,126.0$, $125.1,124.5,121.4,115.8,112.7,75.5,39.7,39.6,39.1,31.5,28.3$, $26.7,24.2,22.6,22.3,20.7,16.2,16.0$ (2C). IR (ATR) $\nu_{\max } 3335$, 2924, 2852, 1686, 1471, 1378, 1220, 1095, $939 \mathrm{~cm}^{-1}$. HRMS (EI) m/ $z$ calcd for $\mathrm{C}_{27} \mathrm{H}_{38} \mathrm{O}_{4}\left[\mathrm{M}^{+\bullet}\right]$ 426.2770, found 426.2768 .

(R)-5-Chloro-2,8-dimethyl-2-((4R,8R)-4,8,12-trimethyltridecyl)chroman-6-ol (51). To a solution of $1 \mathrm{~d}(1 \mathrm{~g}, 2.5 \mathrm{mmol}, 1$ equiv) in methanol $(15 \mathrm{~mL})$ was added $\mathrm{N}$-chlorosuccinimide (400 mg, 1.2 equiv). The reaction was stirred at room temperature for $2 \mathrm{~h}$ until completion monitored by TLC (petroleum ether/acetone 8:2). After removal of the solvent under reduced pressure, the crude residue was taken into hexane and filtered on a Celite pad. The filtrate was concentrated under reduced pressure and purified on silica gel flash chromatography using a 95:5 mixture of petroleum ether/acetone as the mobile phase, leading to 5 -chloro- $\delta$-tocopherol $\mathbf{5 1}$ with $95 \%$ yield. Pale-yellow oil. $R_{f}=0.74$ (petroleum ether/acetone 8:2). ${ }^{1} \mathrm{H}$ NMR $\left(400 \mathrm{MHz}, \mathrm{CDCl}_{3}\right) \delta_{\mathrm{H}} 6.70(\mathrm{~d}, J=0.7 \mathrm{~Hz}, 1 \mathrm{H}), 5.04(\mathrm{~s}, 1 \mathrm{H}, \mathrm{OH})$, $2.71(\mathrm{q}, J=6.7 \mathrm{~Hz}, 2 \mathrm{H}), 2.12(\mathrm{~d}, J=0.7 \mathrm{~Hz}, 3 \mathrm{H}), 1.86-1.72(\mathrm{~m}$, $2 \mathrm{H}), 1.54-1.47(\mathrm{~m}, 4 \mathrm{H}), 1.44-1.32(\mathrm{~m}, 4 \mathrm{H}), 1.31-1.17(\mathrm{~m}, 11 \mathrm{H})$, $1.15-1.00(\mathrm{~m}, 5 \mathrm{H}), 0.88-0.82(\mathrm{~m}, 12 \mathrm{H}) .{ }^{13} \mathrm{C}$ NMR $(100 \mathrm{MHz}$, $\left.\mathrm{CDCl}_{3}\right) \delta_{\mathrm{C}} 146.2,143.9,126.2,118.8,116.5,115.3,75.5,39.6,39.5$, 37.6, 37.5, 37.4, 32.9, 32.8, 31.0, 29.8, 28.1, 24.9, 24.6, 23.9, 22.9, $22.8,21.4,21.1,19.9,19.8,16.1$. HRMS (ESI) $\mathrm{m} / \mathrm{z}$ calcd for $\mathrm{C}_{27} \mathrm{H}_{44} \mathrm{ClO}_{2}[\mathrm{M}-\mathrm{H}]^{-}$435.3030, found 435.3033.

(R)-5-Chloro-6-hydroxy-2,8-dimethyl-2-((4R,8R)-4, 8, 12trimethyltridecyl)chromane-7-carbaldehyde (2). To a stirred solution of 51 (500 mg, $1.14 \mathrm{mmol})$ in dry THF $(20 \mathrm{~mL})$ were added magnesium chloride (1.085 g, 10 equiv), paraformaldehyde (1.094 g, 32 equiv), and triethylamine $(4.8 \mathrm{~mL}, 32$ equiv) at room temperature. The mixture was stirred under reflux until the completion of the reaction was observed by TLC. The heterogeneous mixture was cooled down to room temperature, and $1 \mathrm{~N} \mathrm{HCl} \mathrm{(10}$ $\mathrm{mL})$ and $\mathrm{Et}_{2} \mathrm{O}(30 \mathrm{~mL})$ were added dropwise. The organic layer was separated, and the aqueous layer was extracted with $\mathrm{Et}_{2} \mathrm{O}(2 \times 10$ $\mathrm{mL})$. The combined organic extracts were washed with brine $(20$ $\mathrm{mL}$ ), dried over $\mathrm{Na}_{2} \mathrm{SO}_{4}$, and evaporated to dryness. Purification by column chromatography on silica gel, using a petroleum ether/diethyl ether $\left(\mathrm{PE} / \mathrm{Et}_{2} \mathrm{O}\right)$ mixture as the mobile phase (100:0 to 95:5), afforded the desired formylated product 2 with $75 \%$ yield. $R_{f}=0.50$ $\left(\mathrm{Et}_{2} \mathrm{O} /\right.$ petroleum ether 1:9). ${ }^{1} \mathrm{H} \mathrm{NMR}\left(500 \mathrm{MHz}\right.$, acetone- $\left.d_{6}\right) \delta_{\mathrm{H}}$ $12.02(\mathrm{~s}, 1 \mathrm{H}), 10.39(\mathrm{~s}, 1 \mathrm{H}), 2.82-2.85(\mathrm{~m}, 2 \mathrm{H}), 2.49(\mathrm{~s}, 3 \mathrm{H}), 1.85-$ $1.95(\mathrm{~m}, 2 \mathrm{H}), 1.29(\mathrm{~s}, 3 \mathrm{H}), 1.05-1.66(\mathrm{~m}, 21 \mathrm{H}), 0.85-0.88(\mathrm{~m}$, $12 \mathrm{H}) .{ }^{13} \mathrm{C}$ NMR $\left(125 \mathrm{MHz}\right.$, acetone- $\left.d_{6}\right) \delta_{\mathrm{C}} 197.2,153.3,145.6$, 131.4, 128.6, 118.8, 118.5, 76.9, 40.1, 39.9, 38.0 (2C), 38.1 (2C), $33.5,33.3,31.1,28.7,25.5,25.1,22.8,24.0,23.0,22.9,21.6,20.0$, 
20.1, 9.7. HRMS (FAB) $m / z$ calcd for $\mathrm{C}_{28} \mathrm{H}_{45} \mathrm{ClO}_{3}\left[\mathrm{M}^{+\bullet}\right]$ 464.3052, found 464.3050 .

(R)-6-(Methoxymethoxy)-2,8-dimethyl-2-((4R,8R)-4,8,12trimethyltridecyl)chromane-5-carbaldehyde (4). To a solution of aldehyde $3^{38}$ ( $66 \mathrm{mg}, 0,16 \mathrm{mmol}, 1.0$ equiv) in $3 \mathrm{~mL}$ of distilled THF at $-5{ }^{\circ} \mathrm{C}$ under a nitrogen atmosphere was added dropwise $n$-BuLi $1.6 \mathrm{M}$ in hexane $(200 \mu \mathrm{L}, 0.30 \mathrm{mmol}, 1.95$ equiv). The reaction mixture was stirred for $2 \mathrm{~h}$ at $-5{ }^{\circ} \mathrm{C}$. Then, bromomethyl methyl ether ( $30 \mu \mathrm{L}, 0.37 \mathrm{mmol}, 2.4$ equiv) was added, and the resulting mixture was stirred for $20 \mathrm{~min}$. After dilution with EtOAc $(15 \mathrm{~mL})$, the organic layer was washed with a saturated aqueous $\mathrm{NH}_{4} \mathrm{Cl}$ solution, water, and brine ( $15 \mathrm{~mL}$ each), dried over sodium sulfate, and filtered. The solvent was evaporated under reduced pressure. The crude product was purified by preparative TLC using an 8:2 mixture of ether/petroleum ether to lead to $58 \mathrm{mg}$ of 4 ( $80 \%$ yield). $R_{f}=0.30$ $\left(\mathrm{Et}_{2} \mathrm{O} /\right.$ petroleum ether $\left.1: 9\right) .{ }^{1} \mathrm{H}$ NMR $\left(500 \mathrm{MHz}\right.$, acetone- $\left.d_{6}\right) \delta_{\mathrm{H}}$ $10.57(\mathrm{~s}, 1 \mathrm{H}), 7.00(\mathrm{~s}, 1 \mathrm{H}), 5.25(\mathrm{~s}, 2 \mathrm{H}), 3.48(\mathrm{~s}, 3 \mathrm{H}), 3.01-3.11(\mathrm{~m}$, $2 \mathrm{H}), 2.19(\mathrm{~s}, 3 \mathrm{H}), 1.72-1.82(\mathrm{~m}, 2 \mathrm{H}), 1.26(\mathrm{~s}, 3 \mathrm{H}), 1.09-1.59(\mathrm{~m}$, $21 \mathrm{H}), 0.85-0.88(\mathrm{~m}, 12 \mathrm{H}) .{ }^{13} \mathrm{C}$ NMR $\left(125 \mathrm{MHz}\right.$, acetone- $\left.d_{6}\right) \delta_{\mathrm{C}}$ 191.8, 155.6, 147.8, 135.4, 123.0, 122.6, 117.0, 96.0, 76.0, 56.0, 40.2, $40.1,38.1$ (2C), 38.0 (2C), 33.5, 33.3, 31.6, 28.7, 25.5, 25.1, 24.1, 23.0, 22.9, 22.0, 21.6, 20.1, 20.0, 17.4. HRMS (FAB) $\mathrm{m} / z$ calcd for $\mathrm{C}_{30} \mathrm{H}_{50} \mathrm{O}_{4}\left[\mathrm{M}^{+\bullet}\right]$ 474.3704, found 474.3706.

(2E,6E, 10E)-Methyl-13-((R)-6-methoxy-2,8-dimethylchroman-2yl)-2,6,10-trimethyltrideca-2,6,10-trienoate (53). To a solution of sodium hydride $(140 \mathrm{mg}, 3.5 \mathrm{mmol}, 5$ equiv) in dimethyformamide $(5 \mathrm{~mL})$ were added at $0{ }^{\circ} \mathrm{C}$ a solution of $13 \mathrm{~d}(300 \mathrm{mg}, 0.70 \mathrm{mmol}, 1$ equiv) in dimethyformamide $(5 \mathrm{~mL})$ and iodomethane $(174 \mu \mathrm{L}, 2.8$ mmol, 4 equiv). After $15 \mathrm{~min}$ at $0{ }^{\circ} \mathrm{C}$, the reaction was stirred at room temperature for $1 \mathrm{~h}$. Then, the reaction was quenched with water. The resulting mixture was extracted three times with diethyl ether. The combined organic layers were washed with water and brine, dried over anhydrous sodium sulfate, filtered, and concentrated under reduced pressure. The residue was purified by column chromatography on silica gel eluted with a petroleum ether/acetone (98:2) mixture to afford 53 with $67 \%$ yield. Yellow oil; $R_{f}=0.76$ (petroleum ether/ acetone 9:1). ${ }^{1} \mathrm{H}$ NMR $\left(400 \mathrm{MHz}, \mathrm{CDCl}_{3}\right) \delta_{\mathrm{H}} 6.74(\mathrm{td}, J=1.4,7.3$ $\mathrm{Hz}, 1 \mathrm{H}), 6.56(\mathrm{~d}, J=2.7 \mathrm{~Hz}, 1 \mathrm{H}), 6.44(\mathrm{~d}, J=3.0 \mathrm{~Hz}, 1 \mathrm{H}), 5.15-$ $5.12(\mathrm{~m}, 2 \mathrm{H}), 3.73(\mathrm{~s}, 6 \mathrm{H}), 2.75-2.71(\mathrm{~m}, 2 \mathrm{H}), 2.26(\mathrm{dd}, J=7.5$, $15.0 \mathrm{~Hz}, 2 \mathrm{H}), 2.15(\mathrm{~s}, 3 \mathrm{H}), 2.13-2.04(\mathrm{~m}, 6 \mathrm{H}), 1.99-1.95(\mathrm{~m}, 2 \mathrm{H})$, $1.83(\mathrm{~s}, 3 \mathrm{H}), 1.81-1.71(\mathrm{~m}, 2 \mathrm{H}), 1.68-1.51(\mathrm{~m}, 2 \mathrm{H}), 1.59(\mathrm{~s}, 6 \mathrm{H})$, $1.26(\mathrm{~s}, 3 \mathrm{H}) .{ }^{13} \mathrm{C} \mathrm{NMR}\left(100 \mathrm{MHz}, \mathrm{CDCl}_{3}\right) \delta_{\mathrm{C}} 168.8,152.2,146.2$, $142.5,135.1,134.0,127.5,127.4,125.2,124.5,121.0,114.9,111.1$, 75.4, 55.8, 51.8, 39.8, 39.7, 38.3, 31.5, 27.5, 26.7, 24.2, 22.8, 22.3, $16.4,16.1,16.0,12.6$. IR (ATR) $\nu_{\max } 2924,2849,1713,1481,1435$, $1274,1219,1192,1150,1122,1094,1060 \mathrm{~cm}^{-1}$. MS (EI) $\mathrm{m} / z$ calcd for $\mathrm{C}_{29} \mathrm{H}_{42} \mathrm{O}_{4}\left[\mathrm{M}^{+\bullet}\right]$ 454.3, found 454.4.

(6E, 10E)-Methyl-13-((R)-6-hydroxy-2,8-dimethylchroman-2-yl)2,6,10-trimethyltrideca-6,10-dienoate (21). To a solution of methyl $\delta$-garcinoate $\mathbf{5 2}^{6}(110 \mathrm{mg}, 0.25 \mathrm{mmol}, 1$ equiv) in dry methanol (10 $\mathrm{mL})$, magnesium turnings were added (122 mg, $5 \mathrm{mmol}, 20$ equiv). The reaction mixture was stirred at room temperature for $16 \mathrm{~h}$. Then, the reaction was quenched with water. The resulting mixture was extracted 3 times with diethyl ether. The combined organic layers were washed successively with water and brine, dried over anhydrous sodium sulfate, filtered, and concentrated under reduced pressure. The crude residue was purified by column chromatography on silica gel eluted with a petroleum ether/acetone (95:5) mixture to afford the desired reduced product 21 with $66 \%$ yield. Brown oil; $R_{f}=0.45$ (petroleum ether/acetone/dichloromethane 7:2:1). ${ }^{1} \mathrm{H}$ NMR (400 $\left.\mathrm{MHz}, \mathrm{CDCl}_{3}\right) \delta_{\mathrm{H}} 6.48(\mathrm{~d}, J=3.0 \mathrm{~Hz}, 1 \mathrm{H}), 6.39(\mathrm{~d}, J=3.0 \mathrm{~Hz}, 1 \mathrm{H})$, 5.14-5.06 (m, 2H), $3.67(\mathrm{~s}, 3 \mathrm{H}), 2.69(\mathrm{t}, J=6.9 \mathrm{~Hz}, 2 \mathrm{H}), 2.44(\mathrm{dd}, J$ $=7.0,13.0 \mathrm{~Hz}, 1 \mathrm{H}), 2.12(\mathrm{~s}, 3 \mathrm{H}), 2.09-2.02(\mathrm{~m}, 4 \mathrm{H}), 1.98-1.92(\mathrm{~m}$, $4 \mathrm{H}), 1.81-1.71(\mathrm{~m}, 2 \mathrm{H}), 1.67-1.49(\mathrm{~m}, 4 \mathrm{H}), 1.58(\mathrm{~s}, 3 \mathrm{H}), 1.55(\mathrm{~s}$, $3 \mathrm{H}), 1.39-1.33(\mathrm{~m}, 2 \mathrm{H}), 1.26(\mathrm{~s}, 3 \mathrm{H}), 1.14(\mathrm{~d}, J=7.0 \mathrm{~Hz}, 3 \mathrm{H}) .{ }^{13} \mathrm{C}$ NMR $\left(100 \mathrm{MHz}, \mathrm{CDCl}_{3}\right) \delta_{\mathrm{C}} 177.7,148.0,146.0,135.2,134.8,127.4$, $124.6,124.4,121.3,115.8,112.7,75.4,51.7,39.8,39.6,39.5$ (2C), $33.4,31.5,26.6,25.6,24.2,22.6,22.3,17.2,16.2,16.0,15.9$. IR (ATR) $\nu_{\max } 2926,2854,1735,1714,1464,1218,1159,854 \mathrm{~cm}^{-1}$. HRMS (FAB) $m / z$ calcd for $\mathrm{C}_{28} \mathrm{H}_{42} \mathrm{O}_{4}\left[\mathrm{M}^{+\bullet}\right] 442.3083$, found 442.3078 .
(6E,10E)-Methyl-13-((R)-6-methoxy-2,8-dimethylchroman-2-yl)2,6,10-trimethyltrideca-6,10-dienoate (22). 22 was obtained from $\mathbf{5 3}$ with $72 \%$ yield using the same method as described above for $\mathbf{2 1}$. Brown oil; $R_{f}=0.68$ (petroleum ether/acetone/dichloromethane 7:2:1). ${ }^{1} \mathrm{H}$ NMR $\left(400 \mathrm{MHz}, \mathrm{CDCl}_{3}\right) \delta_{\mathrm{H}} 6.56(\mathrm{~d}, J=2.9 \mathrm{~Hz}, 1 \mathrm{H})$, $6.44(\mathrm{~d}, J=2.9 \mathrm{~Hz}, 1 \mathrm{H}), 5.13(\mathrm{td}, J=1.1 \mathrm{~Hz}, 7.1 \mathrm{~Hz}, 1 \mathrm{H}), 5.08(\mathrm{td}, J$ $=1.2 \mathrm{~Hz}, 6.9 \mathrm{~Hz}, 1 \mathrm{H}), 3.73(\mathrm{~s}, 3 \mathrm{H}), 3.66(\mathrm{~s}, 3 \mathrm{H}), 2.75-2.71(\mathrm{~m}, 2 \mathrm{H})$, $2.48-2.39(\mathrm{~m}, 1 \mathrm{H}), 2.15(\mathrm{~s}, 3 \mathrm{H}), 2.13-2.03(\mathrm{~m}, 6 \mathrm{H}), 1.98-1.93(\mathrm{~m}$, $4 \mathrm{H}), 1.85-1.71(\mathrm{~m}, 2 \mathrm{H}), 1.68-1.51(\mathrm{~m}, 2 \mathrm{H}), 1.59(\mathrm{~s}, 3 \mathrm{H}), 1.55(\mathrm{~s}$, $3 \mathrm{H}), 1.41-1.34(\mathrm{~m}, 2 \mathrm{H}), 1.26(\mathrm{~s}, 3 \mathrm{H}), 1.14(\mathrm{~d}, J=7.0 \mathrm{~Hz}, 3 \mathrm{H}) .{ }^{13} \mathrm{C}$ $\mathrm{NMR}\left(100 \mathrm{MHz}, \mathrm{CDCl}_{3}\right) \delta_{\mathrm{C}} 177.5,152.2,146.2,135.2,134.8,127.4$, 124.6, 124.4, 121.0, 114.8, 111.1, 75.4, 55.8, 51.6, 39.8, 39.5 (2C), $33.4,31.5,29.8,26.7,25.6,24.2,22.8,22.3,17.2,16.3,16.0,15.9$. IR (ATR) $\nu_{\max } 2923,2853,1738,1481,1463,1377,1219,1196,1151$, 1061, $855 \mathrm{~cm}^{-1}$. HRMS (ESI) $\mathrm{m} / z$ calcd for $\mathrm{C}_{29} \mathrm{H}_{45} \mathrm{O}_{4}[\mathrm{M}+\mathrm{H}]^{+}$ 457.3318, found 457.3320

(6E, 10E)-13-((R)-6-Hydroxy-2,8-dimethylchroman-2-yl)-2,6,10trimethyltrideca-6,10-dienoic Acid (19b). To a solution of 21 (60 $\mathrm{mg}$, 1 equiv) in methanol, crushed sodium hydroxide $(2 \mathrm{M})$ was added. The mixture was stirred at $70{ }^{\circ} \mathrm{C}$ for $4 \mathrm{~h}$, and then, the reaction was quenched with an aqueous solution of hydrochloric acid (1 M). The resulting mixture was extracted three times with diethyl ether, and the combined organic layers were washed with water and brine, dried over anhydrous sodium sulfate, filtered, and concentrated under reduced pressure. The residue was purified by column chromatography on silica gel eluted with a petroleum ether/acetone (8:2) mixture to afford the corresponding carboxylic acid $19 \mathrm{~b}$ with $61 \%$ yield from 13d (3 steps). Brown oil; $R_{f}=0.26$ (petroleum ether/ acetone/dichloromethane 7:2:1). ${ }^{1} \mathrm{H} \mathrm{NMR}\left(400 \mathrm{MHz}, \mathrm{CDCl}_{3}\right) \delta_{\mathrm{H}}$ $6.48(\mathrm{~d}, J=3.0 \mathrm{~Hz}, 1 \mathrm{H}), 6.38(\mathrm{~d}, J=2.9 \mathrm{~Hz}, 1 \mathrm{H}), 5.14-5.10(\mathrm{~m}$, $2 \mathrm{H}), 2.69(\mathrm{t}, J=6.8 \mathrm{~Hz}, 2 \mathrm{H}), 2.48-2.43(\mathrm{~m}, 1 \mathrm{H}), 2.12(\mathrm{~s}, 3 \mathrm{H})$, $2.10-2.03(\mathrm{~m}, 4 \mathrm{H}), 1.99-1.94(\mathrm{~m}, 4 \mathrm{H}), 1.83-1.71(\mathrm{~m}, 2 \mathrm{H}), 1.67-$ $1.50(\mathrm{~m}, 4 \mathrm{H}), 1.59(\mathrm{~s}, 3 \mathrm{H}), 1.56(\mathrm{~s}, 3 \mathrm{H}), 1.45-1.36(\mathrm{~m}, 2 \mathrm{H}), 1.26(\mathrm{~s}$, $3 \mathrm{H}), 1.17(\mathrm{~d}, J=7.0 \mathrm{~Hz}, 3 \mathrm{H}) .{ }^{13} \mathrm{C}$ NMR $\left(100 \mathrm{MHz}, \mathrm{CDCl}_{3}\right) \delta_{\mathrm{C}}$ $182.9,147.8,146.1,135.2,134.7,127.5,124.6,124.5,121.4,115.8$, $112.7,75.5,39.8,39.6,39.5,39.3,33.2,31.4,26.6,25.4,24.2$, 22.6, $22.3,17.0,16.2,16.0,15.9$. IR (ATR) $\nu_{\max } 2927,1703,1609,1465$, $1378,1219,1097,853,737 \mathrm{~cm}^{-1}$. HRMS (FAB) $\mathrm{m} / z$ calcd for $\mathrm{C}_{27} \mathrm{H}_{40} \mathrm{O}_{4}\left[\mathrm{M}^{+\bullet}\right]$ 428.2927, found 428.2930 .

(6E, 1OE)-13-((R)-6-Methoxy-2,8-dimethylchroman-2-yl)-2,6,10trimethyltrideca-6,10-dienoic Acid (20). 20 was obtained from 22 with $42 \%$ yield from 13d ( 3 steps) using the same method as described above for $19 \mathrm{~b}$. Brown oil; $R_{f}=0.55$ (petroleum ether/ acetone/dichloromethane $7: 2: 1) .{ }^{1} \mathrm{H}$ NMR $\left(400 \mathrm{MHz}, \mathrm{CDCl}_{3}\right) \delta_{\mathrm{H}}$ $6.57(\mathrm{~d}, J=2.8 \mathrm{~Hz}, 1 \mathrm{H}), 6.44(\mathrm{~d}, J=3.0 \mathrm{~Hz}, 1 \mathrm{H}), 5.15-5.08(\mathrm{~m}$, $2 \mathrm{H}), 3.73(\mathrm{~s}, 3 \mathrm{H}), 2.75-2.71(\mathrm{~m}, 2 \mathrm{H}), 2.48-2.43(\mathrm{~m}, 1 \mathrm{H}), 2.16(\mathrm{~s}$, $3 \mathrm{H}), 2.13-2.04(\mathrm{~m}, 6 \mathrm{H}), 1.99-1.95(\mathrm{~m}, 4 \mathrm{H}), 1.85-1.72(\mathrm{~m}, 2 \mathrm{H})$, $1.68-1.51(\mathrm{~m}, 2 \mathrm{H}), 1.59(\mathrm{~s}, 3 \mathrm{H}), 1.57(\mathrm{~s}, 3 \mathrm{H}), 1.46-1.36(\mathrm{~m}, 2 \mathrm{H})$, $1.27(\mathrm{~s}, 3 \mathrm{H}), 1.17(\mathrm{~d}, J=7.0 \mathrm{~Hz}, 3 \mathrm{H}) .{ }^{13} \mathrm{C} \mathrm{NMR}\left(100 \mathrm{MHz}, \mathrm{CDCl}_{3}\right)$ $\delta_{\mathrm{C}} 182.9,152.2,146.2,135.2,134.7,127.4,124.7,124.4,121.0,114.9$, $111.1,75.5,55.8,39.8$ (2C), 39.5, 39.3, 33.2, 31.5, 26.7, 25.4, 24.1, $22.8,22.3,17.0,16.4,16.0,15.9$. IR (ATR) $\nu_{\max } 2922,2852,1705$, $1481,1465,1377,1280,1220,1150,1061,950 \mathrm{~cm}^{-1}$. HRMS (ESI) $\mathrm{m} / z$ calcd for $\mathrm{C}_{28} \mathrm{H}_{41} \mathrm{O}_{4}[\mathrm{M}-\mathrm{H}]^{-} 441.3005$, found 441.3008 .

(6E, 10E)-13-((R)-6-Hydroxy-2,5,8-trimethylchroman-2-yl)-2,6,10trimethyltrideca-6,10-dienoic Acid (19a). To a solution of $19 \mathrm{~b}$ (1 equiv) in ethanol $(0.08 \mathrm{M})$ were added $N, N, N^{\prime}, N^{\prime}$-tetramethyldiaminomethane ( 3 equiv) and paraformaldehyde ( 3 equiv). The reaction mixture was stirred at $120^{\circ} \mathrm{C}$ under microwave irradiation for $1 \mathrm{~h}$. Then, the reaction was quenched with water. The resulting mixture was extracted three times with dichloromethane. The combined organic layers were washed with water and brine, dried over anhydrous sodium sulfate, filtered, and concentrated under reduced pressure. The brown oily crude product was used without further purification. To a solution of 5-dimethylaminomethylchromanol derivative ( 1 equiv) in ethanol $(0.07 \mathrm{M})$ was added sodium cyanoborohydride ( 5 equiv). The reaction mixture was stirred at $120{ }^{\circ} \mathrm{C}$ under microwave irradiation for $45 \mathrm{~min}$. Then, the reaction was quenched with an aqueous solution of hydrochloric acid $(1 \mathrm{M})$. The resulting mixture was extracted three times with diethyl ether. 
The combined organic layers were washed with water and brine, dried over anhydrous sodium sulfate, filtered, and concentrated under reduced pressure. The residue was purified by column chromatography on silica gel eluted with a petroleum ether/acetone $(9: 1)$ mixture to afford $19 \mathrm{a}$ with $62 \%$ yield. ${ }^{1} \mathrm{H}$ NMR $\left(400 \mathrm{MHz}, \mathrm{CDCl}_{3}\right)$ $\delta_{\mathrm{H}} 6.48(\mathrm{~s}, 1 \mathrm{H}), 5.10(\mathrm{~m}, 2 \mathrm{H}), 2.60(\mathrm{q}, J=6.8 \mathrm{~Hz}, 2 \mathrm{H}), 2.46(\mathrm{~m}$, $1 \mathrm{H}), 2.11(\mathrm{~s}, 3 \mathrm{H}), 2.08(\mathrm{~s}, 3 \mathrm{H}), 2.08-2.01(\mathrm{~m}, 3 \mathrm{H}), 2.01-1.89(\mathrm{~m}$, $4 \mathrm{H}), 1.91-1.69(\mathrm{~m}, 2 \mathrm{H}), 1.69-1.60(\mathrm{~m}, 2 \mathrm{H}), 1.59(\mathrm{~s}, 3 \mathrm{H}), 1.56(\mathrm{~s}$, $3 \mathrm{H}), 1.50-1.45(\mathrm{~m}, 1 \mathrm{H}), 1.43-1.38(\mathrm{~m}, 3 \mathrm{H}), 1.25(\mathrm{~s}, 3 \mathrm{H}), 1.18(\mathrm{~s}$, $3 \mathrm{H}), 1.16(\mathrm{~s}, 3 \mathrm{H}) .{ }^{13} \mathrm{C}$ NMR $\left(100 \mathrm{MHz}, \mathrm{CDCl}_{3}\right) \delta_{\mathrm{C}} 182.5,146.0$, $145.8,135.1,134.7,124.7,124.5,124.2,120.5,119.3,115.4,74.4$, $39.8,39.5,39.4,39.3,33.2,31.6,26.7,25.4,23.9$ (2C), 22.3, 20.9, 17.0, 16.0, 15.9, 11.1. HRMS (ESI) $m / z$ calcd for $\mathrm{C}_{28} \mathrm{H}_{41} \mathrm{O}_{4}[\mathrm{M}-$ $\mathrm{H}]^{-}$441.3005, found 441.3004.

(4E,8E)-11-((R)-2,8-Dimethyl-6-(tosyloxy)chroman-2-yl)-4,8-dimethylundeca-4,8-dienoic Acid (55). To a solution of $54^{39}(198 \mathrm{mg}$, $0.38 \mathrm{mmol}, 1$ equiv) in 1,4-dioxane $(7.5 \mathrm{~mL})$ at $0{ }^{\circ} \mathrm{C}$ were added sulfamic acid $(59 \mathrm{mg}, 0.60 \mathrm{mmol}, 1.6$ equiv), 2-methyl-2-butene $(2.4$ $\mathrm{mL}, 18.9 \mathrm{mmol}, 50$ equiv), and a solution of sodium chlorite $(60 \mathrm{mg}$, $0.53 \mathrm{mmol}, 1.4$ equiv) in water $(2.6 \mathrm{~mL})$. The reaction mixture was stirred at $0{ }^{\circ} \mathrm{C}$ for $2 \mathrm{~h}$. Then, the reaction was quenched with sodium sulfite and diluted with water. The resulting mixture was extracted three times with diethyl ether. The combined organic layers were washed with water and brine, dried over anhydrous sodium sulfate, filtered, and concentrated under reduced pressure. The crude product 55 can be used in the next step without further purification. $R_{f}=0.31$ (petroleum ether/acetone 8:2). ${ }^{1} \mathrm{H}$ NMR $\left(400 \mathrm{MHz}, \mathrm{CDCl}_{3}\right) \delta_{\mathrm{H}} 7.72$ $(\mathrm{d}, J=8.0 \mathrm{~Hz}, 2 \mathrm{H}), 7.31(\mathrm{~d}, J=7.9 \mathrm{~Hz}, 2 \mathrm{H}), 6.55(\mathrm{~s}, 1 \mathrm{H}), 6.52(\mathrm{~s}$, $1 \mathrm{H}), 5.14-5.09(\mathrm{~m}, 2 \mathrm{H}), 2.67-2.63(\mathrm{~m}, 2 \mathrm{H}), 2.45(\mathrm{~s}, 3 \mathrm{H}), 2.45-$ $2.42(\mathrm{~m}, 2 \mathrm{H}), 2.31-2.27(\mathrm{~m}, 2 \mathrm{H}), 2.05(\mathrm{~s}, 3 \mathrm{H}), 2.10-2.03(\mathrm{~m}, 4 \mathrm{H})$, $1.98-1.94(\mathrm{~m}, 2 \mathrm{H}), 1.81-1.69(\mathrm{~m}, 2 \mathrm{H}), 1.68-1.50(\mathrm{~m}, 2 \mathrm{H}), 1.60(\mathrm{~s}$, $3 \mathrm{H}), 1.57(\mathrm{~s}, 3 \mathrm{H}), 1.25(\mathrm{~s}, 3 \mathrm{H}) .{ }^{13} \mathrm{C}$ NMR $\left(100 \mathrm{MHz}, \mathrm{CDCl}_{3}\right) \delta_{\mathrm{C}}$ $179.3,150.8,145.1,131.5,135.2,133.1,132.9,129.7$ (2C), 128.7 (2C), 127.6, 125.3, 124.3, 122.0, 121.2, 120.3, 76.3, 39.9, 39.6, 34.4 33.0, 31.0, 26.6, 24.2, 22.4, 22.2, 21.9, 16.2, 16.1, 16.0. IR (ATR) $\nu_{\max }$ 2923, 1707, 1598, 1473, 1449, 1372, 1225, 1094, 1049, 814, 696, 552 $\mathrm{cm}^{-1}$. HRMS (FAB) $\mathrm{m} / z$ calcd for $\mathrm{C}_{31} \mathrm{H}_{40} \mathrm{O}_{6} \mathrm{~S}\left[\mathrm{M}^{+\bullet}\right] 540.2546$, found 540.2544 .

(4E,8E)-11-((R)-6-Hydroxy-2,8-dimethylchroman-2-yl)-4,8-dimethylundeca-4,8-dienoic Acid (15b). To a solution of $55(175 \mathrm{mg}$, $0.32 \mathrm{mmol}, 1$ equiv) in methanol $(6 \mathrm{~mL})$ was added sodium hydroxide $(467 \mathrm{mg})$. The mixture was stirred at $70{ }^{\circ} \mathrm{C}$ for $1.5 \mathrm{~h}$. Then, the reaction was quenched with an aqueous solution of hydrochloric acid $(1 \mathrm{M})$. The resulting mixture was extracted three times with ethyl acetate. The combined organic layers were washed with water and brine, dried over anhydrous sodium sulfate, filtered, and concentrated under reduced pressure. The residue was purified by column chromatography on silica gel eluted with a petroleum ether/ acetone (8:2) mixture to afford the desired product $15 \mathrm{~b}$ with $77 \%$ yield over two steps from 54. Yellow oil; $R_{f}=0.25$ (petroleum ether/ acetone 8:2). ${ }^{1} \mathrm{H}$ NMR $\left(400 \mathrm{MHz}, \mathrm{CDCl}_{3}\right) \delta_{\mathrm{H}} 6.48(\mathrm{~d}, J=2.6 \mathrm{~Hz}$, $1 \mathrm{H}), 6.38(\mathrm{~d}, J=2.6 \mathrm{~Hz}, 1 \mathrm{H}), 5.16-5.10(\mathrm{~m}, 2 \mathrm{H}), 2.69(\mathrm{t}, J=7.0 \mathrm{~Hz}$, $2 \mathrm{H}), 2.44(\mathrm{t}, J=7.8 \mathrm{~Hz}, 2 \mathrm{H}), 2.29(\mathrm{t}, J=7.8 \mathrm{~Hz}, 2 \mathrm{H}), 2.13(\mathrm{~s}, 3 \mathrm{H})$, 2.13-2.04 (m, 4H), 1.98-1.95 (m, 2H), 1.83-1.71 (m, 2H), 1.70$1.50(\mathrm{~m}, 2 \mathrm{H}), 1.60(\mathrm{~s}, 3 \mathrm{H}), 1.58(\mathrm{~s}, 3 \mathrm{H}), 1.26(\mathrm{~s}, 3 \mathrm{H}) .{ }^{13} \mathrm{C} \mathrm{NMR}$ $\left(100 \mathrm{MHz}, \mathrm{CDCl}_{3}\right) \delta_{\mathrm{C}} 179.6,147.9,146.0,134.9,133.1,127.5,125.4$, 124.6, 121.4, 115.8, 112.8, 75.4, 39.6 (2C), 34.4, 33.1, 31.5, 26.6, 24.2, 22.6, 22.3, 16.2, 16.1, 16.0. IR (ATR) $\nu_{\max } 2921,1707,1469,1218$, $1146,1095,933,853 \mathrm{~cm}^{-1}$. HRMS (EI) $\mathrm{m} / z$ calcd for $\mathrm{C}_{24} \mathrm{H}_{34} \mathrm{O}_{4}$ $\left[\mathrm{M}^{\bullet \bullet}\right]$ 386.2457, found 386.2455.

(4E,8E)-11-((R)-6-Hydroxy-2,5,7,8-tetramethylchroman-2-yl)-4,8dimethylundeca-4,8-dienoic Acid (15a). To a solution of $\mathbf{1 5 b}$ (1 equiv) in 1,4-dioxane $(0.08 \mathrm{M})$ were added $N, N, N^{\prime}, N^{\prime}$-tetramethyldiaminomethane (20 equiv) and paraformaldehyde ( 20 equiv). The reaction mixture was stirred at $140{ }^{\circ} \mathrm{C}$ under microwave irradiation. Completion of the reaction was monitored by TLC. Then, the reaction was quenched with water. The resulting mixture was extracted three times with dichloromethane. The combined organic layers were washed with water and brine, dried over anhydrous sodium sulfate, filtered, and concentrated under reduced pressure.
The brown oily crude product was used without further purification. To a solution of $\alpha$-5,7-bis(dimethylaminomethyl)-tocodienol derivative ( 1 equiv) in ethanol $(0.06 \mathrm{M})$ was added sodium cyanoborohydride ( 20 equiv). The reaction mixture was stirred at $150{ }^{\circ} \mathrm{C}$ under microwave irradiation for $0.75-1.5 \mathrm{~h}$. Then, the reaction was quenched with an aqueous solution of hydrochloric acid (1 M). The resulting mixture was extracted three times with diethyl ether. The combined organic layers were washed with water and brine, dried over anhydrous sodium sulfate, filtered, and concentrated under reduced pressure. The residue was purified by column chromatography on silica gel eluted with a petroleum ether/acetone mixture to afford 15a with $75 \%$ yield. Yellow oil; $R_{f}=0.22$ (petroleum ether/ acetone 8:2). ${ }^{1} \mathrm{H}$ NMR $\left(400 \mathrm{MHz}, \mathrm{CDCl}_{3}\right) \delta_{\mathrm{H}} 5.16-5.11(\mathrm{~m}, 2 \mathrm{H})$, $2.62(\mathrm{t}, J=6.8 \mathrm{~Hz}, 2 \mathrm{H}), 2.46-2.42(\mathrm{~m}, 2 \mathrm{H}), 2.31-2.27(\mathrm{~m}, 2 \mathrm{H})$, $2.16(\mathrm{~s}, 3 \mathrm{H}), 2.12(\mathrm{~s}, 3 \mathrm{H}), 2.11(\mathrm{~s}, 3 \mathrm{H}), 2.09-2.04(\mathrm{~m}, 4 \mathrm{H}), 1.98-$ $1.94(\mathrm{~m}, 2 \mathrm{H}), 1.87-1.74(\mathrm{~m}, 2 \mathrm{H}), 1.68-1.50(\mathrm{~m}, 2 \mathrm{H}), 1.60(\mathrm{~s}, 3 \mathrm{H})$, $1.59(\mathrm{~s}, 3 \mathrm{H}), 1.25(\mathrm{~s}, 3 \mathrm{H}) .{ }^{13} \mathrm{C}$ NMR $\left(100 \mathrm{MHz}, \mathrm{CDCl}_{3}\right) \delta_{\mathrm{C}} 179.5$, 145.6, 144.7, 134.9, 133.1, 125.4, 124.7, 122.8, 121.2, 118.7, 117.5, 74.4, 39.6 (2C), 34.4, 33.0, 31.7, 26.6, 23.8, 22.3, 20.9, 16.1, 16.0, $12.4,11.9,11.4$. IR (ATR) $\nu_{\max } 3459,2922,2852,1708,1453,1378$, $1249,1087 \mathrm{~cm}^{-1}$. HRMS (ESI) $\mathrm{m} / z$ calcd for $\mathrm{C}_{26} \mathrm{H}_{37} \mathrm{O}_{4}[\mathrm{M}-\mathrm{H}]^{-}$ 413.2692, found 413.2689 .

(R)-Methyl-6-hydroxy-2-((3E,7E,11E)-13-methoxy-4,8,12-trimethyl-13-oxotrideca-3,7,11-trien-1-yl)-2,8-dimethylchroman-5-carboxylate (25). To a solution of diacid $56^{47}$ ( 1 equiv) in dimethylformamide $(0.13 \mathrm{M})$ were added sodium bicarbonate (4 equiv) and iodomethane (4 equiv). The reaction mixture was stirred at $120^{\circ} \mathrm{C}$ under microwave irradiation for $2 \mathrm{~h}$. Then, the reaction was quenched with water. The resulting mixture was extracted three times with diethyl ether. The combined organic layers were washed with water and brine, dried over anhydrous sodium sulfate, filtered, and concentrated under reduced pressure. The residue was purified by column chromatography on silica gel eluted with a petroleum ether/ acetone mixture $95: 5$ to afford 25 with $85 \%$ yield. Colorless oil; $R_{f}=$ 0.3 (petroleum ether/ethyl acetate 9:1). ${ }^{1} \mathrm{H}$ NMR $\left(400 \mathrm{MHz}, \mathrm{CDCl}_{3}\right)$ $\delta_{\mathrm{H}} 10.83(\mathrm{~s}, 1 \mathrm{H}), 6.73(\mathrm{dd}, J=7.3,5.9 \mathrm{~Hz}, 1 \mathrm{H}), 6.68(\mathrm{~s}, 1 \mathrm{H}), 5.17-$ $5.08(\mathrm{~m}, 2 \mathrm{H}), 3.93(\mathrm{~s}, 3 \mathrm{H}), 3.72(\mathrm{~s}, 3 \mathrm{H}), 2.98(\mathrm{t}, J=6.9 \mathrm{~Hz}, 2 \mathrm{H})$, $2.26(\mathrm{~s}, 2 \mathrm{H}), 2.19-2.15(\mathrm{~m}, 3 \mathrm{H}), 2.14-2.03(\mathrm{~m}, 6 \mathrm{H}), 1.97(\mathrm{~d}, J=7.9$ $\mathrm{Hz}, 2 \mathrm{H}), 1.82(\mathrm{~d}, J=1.2 \mathrm{~Hz}, 3 \mathrm{H}), 1.74(\mathrm{~d}, J=6.8 \mathrm{~Hz}, 2 \mathrm{H}), 1.64-$ $1.53(\mathrm{~m}, 8 \mathrm{H}), 1.25(\mathrm{~s}, 3 \mathrm{H}) .{ }^{13} \mathrm{C}$ NMR $\left(100 \mathrm{MHz}, \mathrm{CDCl}_{3}\right) \delta_{\mathrm{C}} 172.2$, $168.8,156.3,145.3,142.5,136.3,135.2,134.0,127.5,125.2,124.4$, $120.8,117.6,109.0,74.5,52.0,51.8,39.7,39.5,38.3,31.6,27.5,26.7$, $23.7,23.0,22.2,17.2,16.1,16.0,12.5$. HRMS (ESI) $\mathrm{m} / z$ calcd for $\mathrm{C}_{30} \mathrm{H}_{42} \mathrm{O}_{6} \mathrm{Na}[\mathrm{M}+\mathrm{Na}]^{+}$521.2879, found 521.2878.

(2R)-2,8,-Dimethyl-2-[(3E,7E)-4,8,12-trimethyldeca-3,7,11-trien1-yl]-3,4-dihydro-2H-1-benzopyran-6-yl-4-methylbenzene-1-sulfonate (57). To a solution of $6 \mathrm{~d}(600 \mathrm{mg} ; 1.51 \mathrm{mmol} ; 1$ equiv) in dichloromethane $(33 \mathrm{~mL})$ were added 4-toluenesulfonyl chloride (316.5 mg; $1.66 \mathrm{mmol} ; 1.1$ equiv) and trimethylamine $(252.2 \mu \mathrm{L}$; $1.81 \mathrm{mmol} ; 1.2$ equiv). The reaction mixture was stirred at room temperature for $4 \mathrm{~h}$. Then, the reaction was quenched with a saturated aqueous solution of sodium bicarbonate after being extracted 3 times with diethyl ether. The combined organic layers were washed twice with water and once with brine and afterward dried over anhydrous sodium sulfate, filtrated through cotton, and evaporated under reduced pressure. The residue was purified by automated flash chromatography on silica gel eluted with a mixture of petroleum ether/acetone (9:1). The desired product was obtained in $60 \%$ yield. Light-brown oil, $R_{f}=0.43$ (petroleum ether/acetone 8:2) ${ }^{1} \mathrm{H}$ NMR $\left(400 \mathrm{MHz}, \mathrm{CDCl}_{3}\right) \delta_{\mathrm{H}} 7.72(\mathrm{~d}, J=8.4 \mathrm{~Hz}, 2 \mathrm{H}), 7.31(\mathrm{~d}, J=7.9 \mathrm{~Hz}$, $2 \mathrm{H}), 6.56(\mathrm{~d}, J=2.6 \mathrm{~Hz}, 1 \mathrm{H}), 6.52(\mathrm{~d}, J=2.4 \mathrm{~Hz}, 1 \mathrm{H}), 5.14-5.07$ $(\mathrm{m}, 3 \mathrm{H}), 2.67-2.63(\mathrm{~m}, 2 \mathrm{H}), 2.45(\mathrm{~s}, 3 \mathrm{H}), 2.13-2.02(\mathrm{~m}, 6 \mathrm{H}), 2.05$ $(\mathrm{s}, 3 \mathrm{H}), 1.99-1.94(\mathrm{~m}, 4 \mathrm{H}), 1.82-1.70(\mathrm{~m}, 2 \mathrm{H}), 1.67(\mathrm{~s}, 3 \mathrm{H}), 1.64-$ $1.52(\mathrm{~m}, 2 \mathrm{H}), 1.59(\mathrm{~s}, 3 \mathrm{H}), 1.58(\mathrm{~s}, 6 \mathrm{H}), 1.25(\mathrm{~s}, 3 \mathrm{H}) .{ }^{13} \mathrm{C}$ NMR $\left(100 \mathrm{MHz}, \mathrm{CDCl}_{3}\right) \delta_{\mathrm{C}} 150.8,145.1,141.5,135.5,135.2,132.9,131.4$, $129.7(2 \mathrm{C}), 128.7$ (2C), 127.6, 124.5, 124.2, 124.1, 122.0, 121.2, $120.3,76.3,39.9,39.8$ (2C), 31.0, 26.9, 26.7, 25.9, 24.2, 22.4, 22.2, $21.8,17.8,16.2,16.1,16.0$. IR (ATR) $\nu_{\max } 2919,2853,1473,1449$, $1373,1189,1093,984,813,581 \mathrm{~cm}^{-1}$. HRMS $(\mathrm{FAB}) \mathrm{m} / z$ calcd for $\mathrm{C}_{34} \mathrm{H}_{46} \mathrm{O}_{4} \mathrm{~S}\left[\mathrm{M}^{+}\right.$550.3117, found 550.3116. 
Cross-Metathesis Procedure for the Preparation of 58-60. To a solution of tosylated $\delta$-tocotrienol $57(30 \mathrm{mg}, 0.06 \mathrm{mmol}, 1$ equiv) in degassed deuterated chloroform $(0.7 \mathrm{~mL})$ were added methyl acrylate $(10.8 \mu \mathrm{L}, 0.12 \mathrm{mmol}, 2.4$ equiv) and Grubbs-II catalyst (0.1 equiv). The reaction mixture was refluxed for 3 days. Then, the solvent was removed under reduced pressure. The residue was purified by preparative TLC on silica gel eluted with a cyclohexane/ethyl acetate mixture $(7: 2)$.

(2E,6E, 10E)-Methyl-13-((R)-2,8-dimethyl-6-(tosyloxy)chroman-2yl)-6,10-dimethyltrideca-2,6,10-trienoate (58). 58 was obtained from 57 and methyl acrylate with $10 \%$ yield. Yellow oil; $R_{f}=0.58$ (cyclohexane/ethyl acetate 7:2). ${ }^{1} \mathrm{H}$ NMR $\left(400 \mathrm{MHz}, \mathrm{CDCl}_{3}\right) \delta_{\mathrm{H}}$ $7.72(\mathrm{~d}, J=7.8 \mathrm{~Hz}, 2 \mathrm{H}), 7.31(\mathrm{~d}, J=8.0 \mathrm{~Hz}, 2 \mathrm{H}), 6.98-6.91(\mathrm{~m}$, $1 \mathrm{H}), 6.56(\mathrm{~s}, 1 \mathrm{H}), 6.52(\mathrm{~s}, 1 \mathrm{H}), 5.81(\mathrm{~d}, J=15.5 \mathrm{~Hz}, 1 \mathrm{H}), 5.14-5.10$ $(\mathrm{m}, 2 \mathrm{H}), 3.72(\mathrm{~s}, 3 \mathrm{H}), 2.69-2.61(\mathrm{~m}, 2 \mathrm{H}), 2.45(\mathrm{~s}, 3 \mathrm{H}), 2.31-2.26$ $(\mathrm{m}, 2 \mathrm{H}), 2.12-2.08(\mathrm{~m}, 6 \mathrm{H}), 2.05(\mathrm{~s}, 3 \mathrm{H}), 1.98-1.94(\mathrm{~m}, 2 \mathrm{H})$, $1.82-1.70(\mathrm{~m}, 2 \mathrm{H}), 1.67-1.50(\mathrm{~m}, 2 \mathrm{H}), 1.58(\mathrm{~s}, 6 \mathrm{H}), 1.25(\mathrm{~s}, 3 \mathrm{H})$. ${ }^{13} \mathrm{C}$ NMR $\left(100 \mathrm{MHz}, \mathrm{CDCl}_{3}\right) \delta_{\mathrm{C}} 167.3,150.8,149.5,145.1,141.5$, $136.3,133.6,133.0,129.7$ (2C), 128.7 (2C), 127.6, 125.3, 124.2, 122.0, 121.2, 121.0, 120.3, 76.3, 51.6, 39.9, 39.7, 38.0, 31.0, 30.9, 26.6, 24.2, 22.4, 22.2, 21.9, 16.2, 16.1, 16.0. IR (ATR) $\nu_{\max } 2925,2852$, $1722,1473,1450,1371,1189,1174,1093,984 \mathrm{~cm}^{-1}$. MS (EI) $\mathrm{m} / z$ calcd for $\mathrm{C}_{34} \mathrm{H}_{44} \mathrm{O}_{6} \mathrm{~S}\left[\mathrm{M}^{+\bullet}\right] 580.3$, found 580.3 .

(2E,6E)-Methyl-9-((R)-2,8-dimethyl-6-(tosyloxy)chroman-2-yl)-6methylnona-2,6-dienoate (59). 59 was obtained from 57 and methyl acrylate with $30 \%$ yield. Yellow oil; $R_{f}=0.53$ (cyclohexane/ethyl acetate $7: 2) .{ }^{1} \mathrm{H}$ NMR $\left(400 \mathrm{MHz}, \mathrm{CDCl}_{3}\right) \delta_{\mathrm{H}} 7.73(\mathrm{~d}, J=8.0 \mathrm{~Hz}$, $2 \mathrm{H}), 7.31(\mathrm{~d}, J=7.9 \mathrm{~Hz}, 2 \mathrm{H}), 6.98-6.90(\mathrm{~m}, 1 \mathrm{H}), 6.56(\mathrm{~s}, 1 \mathrm{H}), 6.53$ $(\mathrm{s}, 1 \mathrm{H}), 5.81(\mathrm{~d}, J=15.7 \mathrm{~Hz}, 1 \mathrm{H}), 5.17-5.13(\mathrm{~m}, 1 \mathrm{H}), 3.71(\mathrm{~s}, 3 \mathrm{H})$, $2.68-2.61(\mathrm{~m}, 2 \mathrm{H}), 2.45(\mathrm{~s}, 3 \mathrm{H}), 2.32-2.26(\mathrm{~m}, 2 \mathrm{H}), 2.12-2.09(\mathrm{~m}$, $2 \mathrm{H}), 2.05(\mathrm{~s}, 3 \mathrm{H}), 1.81-1.67(\mathrm{~m}, 4 \mathrm{H}), 1.62-1.49(\mathrm{~m}, 2 \mathrm{H}), 1.58(\mathrm{~s}$, $3 \mathrm{H}), 1.25(\mathrm{~s}, 3 \mathrm{H}) .{ }^{13} \mathrm{C} \mathrm{NMR}\left(100 \mathrm{MHz}, \mathrm{CDCl}_{3}\right) \delta_{\mathrm{C}} 167.3,150.8$, $149.4,145.1,141.6,133.9,133.0,129.7$ (2C), 128.7 (2C), 127.6, 125.3, 122.0, 121.2, 121.1, 120.3, 76.2, 51.6, 39.9, 38.0, 31.0, 30.8, 24.1, 22.4, 22.2, 21.8, 16.2, 15.9. IR (ATR) $\nu_{\max } 2925,2852,1722$, $1473,1450,1371,1189,1176,1093,984 \mathrm{~cm}^{-1}$. MS (EI) $\mathrm{m} / z$ calcd for $\mathrm{C}_{29} \mathrm{H}_{36} \mathrm{O}_{6} \mathrm{~S}\left[\mathrm{M}^{+\bullet}\right]$ 512.2, found 512.3.

(R,E)-Methyl-5-(2,8-dimethyl-6-(tosyloxy)chroman-2-yl)pent-2enoate (60). 60 was obtained from 57 and methyl acrylate with $49 \%$ yield. Yellow oil; $R_{f}=0.44$ (cyclohexane/ethyl acetate 7:2). ${ }^{1} \mathrm{H}$ NMR $\left(400 \mathrm{MHz}, \mathrm{CDCl}_{3}\right) \delta_{\mathrm{H}} 7.73(\mathrm{~d}, J=8.1 \mathrm{~Hz}, 2 \mathrm{H}), 7.31(\mathrm{~d}, J=8.0 \mathrm{~Hz}$, $2 \mathrm{H}), 7.03-6.96(\mathrm{~m}, 1 \mathrm{H}), 6.57(\mathrm{~s}, 1 \mathrm{H}), 6.53(\mathrm{~s}, 1 \mathrm{H}), 5.83(\mathrm{~d}, J=15.6$ $\mathrm{Hz}, 1 \mathrm{H}), 3.72(\mathrm{~s}, 3 \mathrm{H}), 2.73-2.61(\mathrm{~m}, 2 \mathrm{H}), 2.45(\mathrm{~s}, 3 \mathrm{H}), 2.39-2.33$ $(\mathrm{m}, 2 \mathrm{H}), 2.04(\mathrm{~s}, 3 \mathrm{H}), 1.82-1.68(\mathrm{~m}, 4 \mathrm{H}), 1.25(\mathrm{~s}, 3 \mathrm{H}) .{ }^{13} \mathrm{C}$ NMR $\left(100 \mathrm{MHz}, \mathrm{CDCl}_{3}\right) \delta_{\mathrm{C}} 167.2,150.4,149.4,145.1,141.7,132.9,129.7$ (2C), 128.7 (2C), 127.6, 122.2, 121.1, 121.0, 120.4, 75.8, 51.6, 38.3, 31.1, 26.6, 23.9, 22.3, 21.9, 16.2. IR (ATR) $\nu_{\max } 2926,2851,1722$, $1473,1371,1189,1177,1094,984 \mathrm{~cm}^{-1}$. MS (EI) $\mathrm{m} / z$ calcd for $\mathrm{C}_{24} \mathrm{H}_{28} \mathrm{O}_{6} \mathrm{~S}\left[\mathrm{M}^{+\bullet}\right]$ 444.2, found 444.2.

(R,E)-Methyl-5-(2,8-dimethyl-6-(tosyloxy)chroman-2-yl)-2-methylpent-2-enoate (61). To a solution of $57(30 \mathrm{mg}, 0.05 \mathrm{mmol}, 1$ equiv) in degassed deuterated chloroform $(0.7 \mathrm{~mL})$ were added methyl methacrylate $(6.4 \mu \mathrm{L}, 0.06 \mathrm{mmol}, 1.2$ equiv) and HoveydaGrubbs-II catalyst ( $3.55 \mathrm{mg}, 0.005 \mathrm{mmol}, 0.1$ equiv). The reaction mixture was stirred under microwave irradiation at $120{ }^{\circ} \mathrm{C}$ for $2.5 \mathrm{~h}$. Then, the solvent was removed under reduced pressure. The residue was purified by preparative TLC on silica gel eluted with a cyclohexane/ethyl acetate mixture 7:2 to afford 61 as an oil with $21 \%$ yield. Yellow oil; $R_{f}=0.41$ (cyclohexane/ethyl acetate 7:2). ${ }^{1} \mathrm{H}$ $\operatorname{NMR}\left(400 \mathrm{MHz}, \mathrm{CDCl}_{3}\right) \delta_{\mathrm{H}} 7.73(\mathrm{~d}, J=8.0 \mathrm{~Hz}, 2 \mathrm{H}), 7.31(\mathrm{~d}, J=7.8$ $\mathrm{Hz}, 2 \mathrm{H}), 6.77(\mathrm{t}, J=7.3 \mathrm{~Hz}, 1 \mathrm{H}), 6.57(\mathrm{~s}, 1 \mathrm{H}), 6.53(\mathrm{~s}, 1 \mathrm{H}), 3.72(\mathrm{~s}$, $3 \mathrm{H}), 2.73-2.62(\mathrm{~m}, 2 \mathrm{H}), 2.45(\mathrm{~s}, 3 \mathrm{H}), 2.34-2.28(\mathrm{~m}, 2 \mathrm{H}), 2.05(\mathrm{~s}$, $3 \mathrm{H}), 1.82(\mathrm{~s}, 3 \mathrm{H}), 1.79-1.69(\mathrm{~m}, 2 \mathrm{H}), 1.67-1.56(\mathrm{~m}, 2 \mathrm{H}), 1.26(\mathrm{~s}$, $3 \mathrm{H}) .{ }^{13} \mathrm{C}$ NMR $\left(100 \mathrm{MHz}, \mathrm{CDCl}_{3}\right) \delta_{\mathrm{C}} 168.7,150.5,145.1,142.2$, $141.7,132.9,129.7(2 \mathrm{C}), 128.7$ (2C), 127.8, 127.6, 122.1, 121.0, $120.4,75.9,51.9,38.6,31.1,24.0,23.0,22.3,21.9,16.2,12.4$. IR (ATR) $\nu_{\max } 2924,2852,1711,1471,1369,1189,1176,1091,982$, $813 \mathrm{~cm}^{-1}$. MS (EI) $\mathrm{m} / z$ calcd for $\mathrm{C}_{25} \mathrm{H}_{30} \mathrm{O}_{6} \mathrm{~S}\left[\mathrm{M}^{+\bullet}\right]$ 458.2, found 458.1 .
Cross-Metathesis Procedure for the Preparation of 62 and 63. To a solution of $57(30 \mathrm{mg}, 0.05 \mathrm{mmol}, 1$ equiv) in degassed deuterated chloroform $(0.7 \mathrm{~mL})$ were added 2-methylene-1,3propanediacetate $(10 \mathrm{mg}, 0.05 \mathrm{mmol}, 1.2$ equiv) and Grubbs-II catalyst $(4.2 \mathrm{mg}, 0.005 \mathrm{mmol}, 0.1$ equiv). The reaction mixture was stirred under microwave irradiation at $120{ }^{\circ} \mathrm{C}$ for $2 \mathrm{~h}$. Then, the solvent was removed under reduced pressure. The residue was purified by preparative TLC on silica gel eluted with a cyclohexane/ ethyl acetate mixture $7: 2$ to afford the desired products as oil.

(R,E)-2-(7-(2,8-Dimethyl-6-(tosyloxy)chroman-2-yl)-4-methylhept-4-en-1-ylidene)propane-1,3-diyl Diacetate (62). 62 was obtained from 57 and 2-methylene-1,3-propanediacetate with $27 \%$ yield. Yellow oil; $R_{f}=0.37$ (cyclohexane/ethyl acetate 7:2). ${ }^{1} \mathrm{H}$ NMR $\left(400 \mathrm{MHz}, \mathrm{CDCl}_{3}\right) \delta_{\mathrm{H}} 7.72(\mathrm{~d}, J=8.3 \mathrm{~Hz}, 2 \mathrm{H}), 7.31(\mathrm{~d}, J=8.0 \mathrm{~Hz}$, $2 \mathrm{H}), 6.56(\mathrm{~d}, J=2.8 \mathrm{~Hz}, 1 \mathrm{H}), 6.52(\mathrm{~d}, J=2.8 \mathrm{~Hz}, 1 \mathrm{H}), 5.74(\mathrm{t}, J=7.3$ $\mathrm{Hz}, 1 \mathrm{H}), 5.13(\mathrm{td}, J=1.1,7.1 \mathrm{~Hz}, 1 \mathrm{H}), 4.64(\mathrm{~s}, 2 \mathrm{H}), 4.55(\mathrm{~s}, 2 \mathrm{H})$, $2.68-2.64(\mathrm{~m}, 2 \mathrm{H}), 2.45(\mathrm{~s}, 3 \mathrm{H}), 2.24(\mathrm{dd}, J=7.4 \mathrm{~Hz}, 15.0 \mathrm{~Hz}, 2 \mathrm{H})$, 2.13-2.01 (m, 4H), $2.05(\mathrm{~s}, 9 \mathrm{H}), 1.80-1.71(\mathrm{~m}, 2 \mathrm{H}), 1.67-1.50(\mathrm{~m}$, $2 \mathrm{H}), 1.58(\mathrm{~s}, 3 \mathrm{H}), 1.25(\mathrm{~s}, 3 \mathrm{H}) .{ }^{13} \mathrm{C} \mathrm{NMR}\left(100 \mathrm{MHz}, \mathrm{CDCl}_{3}\right) \delta_{\mathrm{C}}$ 171.1, 170.9, 150.7, 145.1, 141.5, 136.5, 135.4, 134.3, 132.9, 129.7 (2C), 129.1, 128.7 (2C), 127.5, 125.1, 122.0, 121.2, 120.3, 76.2, 66.8, 59.9, 39.9, 39.1, 31.0, 29.8, 26.3, 24.1, 22.4, 22.2, 21.8, 21.1, 16.2, 15.9. IR (ATR) $\nu_{\max } 2925,2853,1711,1361,1221,1178,735 \mathrm{~cm}^{-1}$. HRMS (FAB) $m / z$ calcd for $\mathrm{C}_{33} \mathrm{H}_{42} \mathrm{O}_{8} \mathrm{~S}[\mathrm{M}]^{+}$598.2600, found 598.2603.

(R)-2-(3-(2,8-Dimethyl-6-(tosyloxy)chroman-2-yl)propylidene)propane-1,3-diyl Diacetate (63). 63 was obtained from 57 and 2methylene-1,3-propanediacetate with $38 \%$ yield. Yellow oil; $R_{f}=0.22$ (cyclohexane/ethyl acetate 7:2). ${ }^{1} \mathrm{H}$ NMR $\left(400 \mathrm{MHz}, \mathrm{CDCl}_{3}\right) \delta_{\mathrm{H}}$ $7.72(\mathrm{~d}, J=8.3 \mathrm{~Hz}, 2 \mathrm{H}), 7.31(\mathrm{~d}, J=8.4 \mathrm{~Hz}, 2 \mathrm{H}), 6.56(\mathrm{~d}, J=2.8 \mathrm{~Hz}$, $1 \mathrm{H}), 6.52(\mathrm{~d}, J=2.8 \mathrm{~Hz}, 1 \mathrm{H}), 5.77(\mathrm{t}, J=7.4 \mathrm{~Hz}, 1 \mathrm{H}), 4.68-4.60(\mathrm{~m}$, $2 \mathrm{H}), 4.55(\mathrm{~s}, 2 \mathrm{H}), 2.69-2.64(\mathrm{~m}, 2 \mathrm{H}), 2.45(\mathrm{~s}, 3 \mathrm{H}), 2.33-2.27(\mathrm{~m}$, $2 \mathrm{H}), 2.05(\mathrm{~s}, 3 \mathrm{H}), 2.03(\mathrm{~s}, 6 \mathrm{H}), 1.81-1.57(\mathrm{~m}, 4 \mathrm{H}), 1.25(\mathrm{~s}, 3 \mathrm{H}) .{ }^{13} \mathrm{C}$ NMR $\left(100 \mathrm{MHz}, \mathrm{CDCl}_{3}\right) \delta_{\mathrm{C}} 171.1,170.9,150.5,145.1,141.7,136.3$, 132.9, 129.7 (2C), 129.4, 128.7 (2C), 127.6, 122.1, 121.0, 120.4, 75.9, 66.7, 59.8, 39.5, 31.0, 24.0, 22.3, 22.1, 21.8, 21.1, 21.0, 16.2. IR (ATR) $\nu_{\max } 2917,2849,1734,1471,1370,1224,1178,734 \mathrm{~cm}^{-1}$. HRMS (FAB) $m / z$ calcd for $\mathrm{C}_{28} \mathrm{H}_{34} \mathrm{O}_{8} \mathrm{~S}\left[\mathrm{M}^{+\bullet}\right]$ 530.1974, found 530.1977.

(R,E)-2-(7-(6-Hydroxy-2,8-dimethylchroman-2-yl)-4-methylhept4-en-1-ylidene)propane-1,3-diol (28). To a solution of 62 (1 equiv) in methanol $(0.03 \mathrm{M})$, potassium hydroxide $(400 \mathrm{mg})$ was added. The mixture was stirred at $70{ }^{\circ} \mathrm{C}$ until completion of the reaction, monitored by TLC. Then, the reaction was quenched with an aqueous solution of hydrochloric acid $(1 \mathrm{M})$. The resulting mixture was extracted three times with dichloromethane. The combined organic layers were washed with water and brine, dried over anhydrous sodium sulfate, filtered, and concentrated under reduced pressure. The residue was purified by column chromatography on silica gel eluted with a petroleum ether/acetone (9:1 to 8:2) mixture to afford 28 with $53 \%$ yield. Pale-yellow oil; $R_{f}=0.26$ (petroleum ether/acetone 7:3). ${ }^{1} \mathrm{H}$ NMR $\left(400 \mathrm{MHz}, \mathrm{CDCl}_{3}\right) \delta_{\mathrm{H}} 6.48(\mathrm{~d}, J=2.4$ $\mathrm{Hz}, 1 \mathrm{H}), 6.39$ (d, $J=2.6 \mathrm{~Hz}, 1 \mathrm{H}), 5.52(\mathrm{t}, J=7.3 \mathrm{~Hz}, 1 \mathrm{H}), 5.13(\mathrm{td}, J$ $=1.1,7.1 \mathrm{~Hz}, 1 \mathrm{H}), 4.29(\mathrm{~s}, 2 \mathrm{H}), 4.20(\mathrm{~s}, 2 \mathrm{H}), 2.69(\mathrm{t}, J=6.7 \mathrm{~Hz}$, $2 \mathrm{H}), 2.52$ (bs, $3 \mathrm{H}), 2.20-2.16(\mathrm{~m}, 2 \mathrm{H}), 2.14-2.08(\mathrm{~m}, 2 \mathrm{H}), 2.12(\mathrm{~s}$, $3 \mathrm{H}), 2.03-2.00(\mathrm{~m}, 2 \mathrm{H}), 1.83-1.70(\mathrm{~m}, 2 \mathrm{H}), 1.66-1.48(\mathrm{~m}, 2 \mathrm{H})$, $1.58(\mathrm{~s}, 3 \mathrm{H}), 1.26(\mathrm{~s}, 3 \mathrm{H}) .{ }^{13} \mathrm{C}$ NMR $\left(100 \mathrm{MHz}, \mathrm{CDCl}_{3}\right) \delta_{\mathrm{C}} 147.9$, $146.0,137.1,134.3,131.0,127.5,125.3,121.4,115.8,112.7,75.4$, $67.9,60.3,39.5,39.4,31.5,26.0,24.2,22.6,22.2,16.2,16.0$. IR (ATR) $\nu_{\max } 3335,2926,1608,1472,1220,1147,994,854 \mathrm{~cm}^{-1}$. HRMS (EI) $\mathrm{m} / z$ calcd for $\mathrm{C}_{22} \mathrm{H}_{32} \mathrm{O}_{4}\left[\mathrm{M}^{+\bullet}\right] 360.2301$, found 360.2299 .

(R)-2-(3-(6-Hydroxy-2,8-dimethylchroman-2-yl)propylidene)propane-1,3-diol (29). 29 was obtained from 63 with $57 \%$ yield using the method described above for the preparation of 28. Pale-yellow oil; $R_{f}=0.21$ (petroleum ether/acetone 7:3). ${ }^{1} \mathrm{H}$ NMR $(400 \mathrm{MHz}$, $\left.\mathrm{CDCl}_{3}\right) \delta_{\mathrm{H}} 6.48(\mathrm{~d}, J=2.4 \mathrm{~Hz}, 1 \mathrm{H}), 6.38(\mathrm{~d}, J=2.8 \mathrm{~Hz}, 1 \mathrm{H}), 5.58(\mathrm{t}$, $J=7.5 \mathrm{~Hz}, 1 \mathrm{H}), 4.31(\mathrm{~m}, 2 \mathrm{H}), 4.20(\mathrm{~s}, 2 \mathrm{H}), 2.70(\mathrm{dd}, J=6.6 \mathrm{~Hz}, 12.9$ $\mathrm{Hz}, 2 \mathrm{H}), 2.24(\mathrm{dd}, J=7.8,16.5 \mathrm{~Hz}, 2 \mathrm{H}), 2.12(\mathrm{~s}, 3 \mathrm{H}), 1.82-1.54(\mathrm{~m}$,

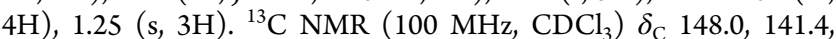
$137.1,131.3,127.5,121.3,115.8,112.8,75.1,67.8,60.2,39.6,31.6$, 24.1, 22.5, 21.8, 16.2. IR (ATR) $\nu_{\max } 3334,2921,1608,1466,1219$, 
$1147,994,854 \mathrm{~cm}^{-1}$. HRMS (FAB) $m / z$ calcd for $\mathrm{C}_{17} \mathrm{H}_{24} \mathrm{O}_{4}\left[\mathrm{M}^{+\bullet}\right]$ 292.1675, found 292.1671 .

(2E,6E, 10E)-13-[(2R)-6-Hydroxy-2,8-dimethyl-3,4-dihydro-2H-1benzopyran-2-yl]-6,10-dimethyltrideca-2,6,10-trienoic Acid (14). 1st step: A $0.02 \mathrm{M}$ solution of $\mathbf{5 8}(26.3 \mathrm{mg}, 1$ equiv) in $4 \mathrm{~mL}$ of a mixture of THF/MeOH/ $/ \mathrm{H}_{2} \mathrm{O}$ (3:1:1) was treated with $\mathrm{LiOH}$ (5.4 mg, 4.3 equiv). The reaction mixture was stirred at $40{ }^{\circ} \mathrm{C}$ overnight. Completion of the reaction was monitored by TLC using a mixture of petroleum ether/acetone/dichloromethane $(7: 2: 1)$ as the mobile phase. The reaction was quenched with $10 \%$ hydrochloric acid and extracted three times with ethyl acetate. The combined organic layers were washed twice with water and once with brine, dried over anhydrous sodium sulfate, and filtered. Removal of the solvent under reduced pressure yielded the corresponding carboxylic acid that was used without further purification. 2nd step: Removal of the tosyl group was achieved in a mixture of methanol $(0.01 \mathrm{M})$ and $2 \mathrm{M}$ aqueous potassium hydroxide solution $(1: 1)$. The reaction mixture was refluxed for $6 \mathrm{~h}$. Completion of the reaction was monitored by TLC using a mixture of petroleum ether/acetone/dichloromethane $(7: 2: 1)$ as the mobile phase. The reaction was quenched with $10 \%$ hydrochloric acid and extracted three times with ethyl acetate. The combined organic layers were washed twice with water and once with brine, dried over anhydrous sodium sulfate, and filtered. Removal of the solvent under reduced pressure yielded the crude phenol derivative. Purification was achieved by silica gel preparative TLC, leading to 14 with $16 \%$ yield from 58. Light-yellow oil; $R_{f}=0.53$ (petroleum ether/acetone/dichloromethane 7:2:1). ${ }^{1} \mathrm{H}$ NMR (400 $\left.\mathrm{MHz}, \mathrm{CDCl}_{3}\right) \delta_{\mathrm{H}} 7.09-7.02(\mathrm{~m}, 1 \mathrm{H}), 6.48(\mathrm{~s}, 1 \mathrm{H}), 6.38(\mathrm{~s}, 1 \mathrm{H})$, 5.86-5.77 (m, $1 \mathrm{H}), 5.16-5.09(\mathrm{~m}, 2 \mathrm{H}), 2.72-2.66(\mathrm{~m}, 2 \mathrm{H}), 2.35-$ $2.23(\mathrm{~m}, 2 \mathrm{H}), 2.16-2.01(\mathrm{~m}, 10 \mathrm{H}), 1.98-1.93(\mathrm{~m}, 2 \mathrm{H}), 1.82-1.71$ $(\mathrm{m}, 2 \mathrm{H}), 1.64-1.52(\mathrm{~m}, 8 \mathrm{H}), 1.26(\mathrm{~s}, 3 \mathrm{H}) .{ }^{13} \mathrm{C}$ NMR $(100 \mathrm{MHz}$, $\left.\mathrm{CDCl}_{3}\right) \delta_{\mathrm{C}} 171.6,152.3,147.8,146.1,134.9,133.4,127.5,125.5$, $124.6,121.3,120.6,115.8,112.7,75.4,39.6,39.5,37.8,31.5,31.0$, 26.5, 24.3, 22.6, 22.3, 16.2, 16.1, 16.0. HRMS (ESI) $\mathrm{m} / z$ calcd for $\mathrm{C}_{26} \mathrm{H}_{35} \mathrm{O}_{4}[\mathrm{M}-\mathrm{H}]^{-}$411.2535, found 411.2531.

(2E,6E)-9-[(2R)-6-Hydroxy-2,8-dimethyl-3,4-dihydro-2H-1-benzopyran-2-yl]-6-methylnona-2,6-dienoic Acid (16). 16 was obtained from 59 with $31 \%$ yield using the two-step procedure described above for 58. Light-yellow oil; $R_{f}=0.47$ (petroleum ether/acetone/ dichloromethane 7:2:1). ${ }^{1} \mathrm{H}$ NMR $\left(400 \mathrm{MHz}, \mathrm{CDCl}_{3}\right) \delta_{\mathrm{H}} 7.08-$ $6.96(\mathrm{~m}, 1 \mathrm{H}), 6.48(\mathrm{~s}, 1 \mathrm{H}), 6.38(\mathrm{~s}, 1 \mathrm{H}), 5.84-5.78(\mathrm{~m}, 1 \mathrm{H}), 5.19-$ $5.13(\mathrm{~m}, 1 \mathrm{H}), 2.71-2.65(\mathrm{~m}, 2 \mathrm{H}), 2.35-2.29(\mathrm{~m}, 2 \mathrm{H}), 2.17-2.07$ (m, 7H), $1.79-1.72(\mathrm{~m}, 2 \mathrm{H}), 1.69-1.47(\mathrm{~m}, 6 \mathrm{H}), 1.26(\mathrm{~s}, 3 \mathrm{H}) .{ }^{13} \mathrm{C}$ NMR $\left(100 \mathrm{MHz}, \mathrm{CDCl}_{3}\right) \delta_{\mathrm{C}} 171.4,152.1,147.8,146.1,133.5,127.5$, 125.7, 121.4, 120.6, 115.8, 112.7, 75.4, 39.6, 37.8, 31.5, 30.9, 24.2, 22.6, 22.3, 16.2, 15.9. HRMS (ESI) $\mathrm{m} / z$ calcd for $\mathrm{C}_{21} \mathrm{H}_{27} \mathrm{O}_{4}[\mathrm{M}-$ $\mathrm{H}]^{-}$343.1909, found 343.1906.

(2E)-5-[(2R)-6-Hydroxy-2,8-dimethyl-3,4-dihydro-2H-1-benzopyran-2-yl]pent-2-enoic Acid (17). 17 was obtained with $17 \%$ yield from 60 using the two-step procedure described above for 58. Lightyellow oil; $17 \%$ total yield; $R_{f}=0.36$ (petroleum ether/acetone/ dichloromethane 7:2:1). ${ }^{1} \mathrm{H}$ NMR $\left(400 \mathrm{MHz}, \mathrm{CDCl}_{3}\right) \delta_{\mathrm{H}} 7.17-7.08$ $(\mathrm{m}, 1 \mathrm{H}), 6.48(\mathrm{~s}, 1 \mathrm{H}), 6.39(\mathrm{~s}, 1 \mathrm{H}), 5.84(\mathrm{~d}, J=15.6 \mathrm{~Hz}, 1 \mathrm{H}), 2.77-$ $2.64(\mathrm{~m}, 2 \mathrm{H}), 2.44-2.38(\mathrm{~m}, 2 \mathrm{H}), 2.11(\mathrm{~s}, 3 \mathrm{H}), 1.87-1.60(\mathrm{~m}, 4 \mathrm{H})$, $1.26(\mathrm{~s}, 3 \mathrm{H}) .{ }^{13} \mathrm{C} \mathrm{NMR}\left(100 \mathrm{MHz}, \mathrm{CDCl}_{3}\right) \delta_{\mathrm{C}} 171.5,152.5,148.0$, 145.7, 127.6, 121.1, 120.5, 115.9, 112.7, 74.9, 37.9, 31.6, 26.8, 23.9, 22.5, 16.2. HRMS (ESI) $\mathrm{m} / z$ calcd for $\mathrm{C}_{16} \mathrm{H}_{19} \mathrm{O}_{4}[\mathrm{M}-\mathrm{H}]^{-}$ 275.1283, found 275.1281.

$(R, E)-5$-(6-Hydroxy-2,8-dimethylchroman-2-yl)-2-methylpent-2enoic Acid (18). To a solution of $\mathbf{6 1}(48 \mathrm{mg}, 0.1 \mathrm{mmol}, 1$ equiv) in a mixture of water/THF $(2: 1 ; 3 \mathrm{~mL})$ was added potassium hydroxide (337 mg). The mixture was stirred at $70{ }^{\circ} \mathrm{C}$ for $18 \mathrm{~h}$. Then, the reaction was quenched with an aqueous solution of hydrochloric acid $(1 \mathrm{M})$. The resulting mixture was extracted three times with diethyl ether. The combined organic layers were washed with water and brine, dried over anhydrous sodium sulfate, filtered, and concentrated under reduced pressure. The residue was purified by preparative TLC eluted with a petroleum ether/acetone (75:25) mixture to afford the desired product 18 with $20 \%$ yield. Yellow oil; $R_{f}=0.4$ (petroleum ether/acetone 7:3). ${ }^{1} \mathrm{H} \mathrm{NMR}\left(400 \mathrm{MHz}, \mathrm{CDCl}_{3}\right) \delta_{\mathrm{H}} 6.92(\mathrm{td}, J=1.4$
$\mathrm{Hz}, 7.5 \mathrm{~Hz}, 1 \mathrm{H}), 6.48(\mathrm{~d}, J=2.5 \mathrm{~Hz}, 1 \mathrm{H}), 6.38(\mathrm{~d}, J=3.0 \mathrm{~Hz}, 1 \mathrm{H})$, $2.74-2.69(\mathrm{~m}, 2 \mathrm{H}), 2.36(\mathrm{dd}, J=7.8 \mathrm{~Hz}, 15.6 \mathrm{~Hz}, 2 \mathrm{H}), 2.12(\mathrm{~s}, 3 \mathrm{H})$, $1.83(\mathrm{~s}, 3 \mathrm{H}), 1.81-1.73(\mathrm{~m}, 3 \mathrm{H}), 1.68-1.61(\mathrm{~m}, 1 \mathrm{H}), 1.27(\mathrm{~s}, 3 \mathrm{H})$. ${ }^{13} \mathrm{C}$ NMR $\left(100 \mathrm{MHz}, \mathrm{CDCl}_{3}\right) \delta_{\mathrm{C}} 172.9,148.0,145.8,145.2,127.5$, 121.2, 115.9, 112.7, 75.0, 38.4, 31.6, 29.4, 23.9, 23.4, 22.5, 16.2, 12.0. IR (ATR) $\nu_{\max } 3365,2925,1682,1639,1607,1470,1426,1378,1291$, $1216,1145,1096,853 \mathrm{~cm}^{-1}$. HRMS (ESI) $\mathrm{m} / z$ calcd for $\mathrm{C}_{17} \mathrm{H}_{21} \mathrm{O}_{4}$ $[\mathrm{M}-\mathrm{H}]^{-} 289.1440$, found 289.1435 .

2-((4E,8E)-11-((R)-6-Acetoxy-2,8-dimethylchroman-2-yl)-4,8-dimethylundeca-4,8-dien-1-ylidene)propane-1,3-diyl Diacetate (65). To a solution of $\delta$-AC $(\mathbf{2 7 d})(289 \mathrm{mg}, 0.67 \mathrm{mmol}, 1$ equiv) in pyridine $(15 \mathrm{~mL})$ was added acetic anhydride $(431 \mu \mathrm{L}, 3.37 \mathrm{mmol}, 5$ equiv). The reaction mixture was stirred at room temperature for 24 h. Then, the reaction was quenched with a saturated aqueous solution of sodium bicarbonate. The resulting mixture was extracted three times with ethyl acetate. The combined organic layers were washed with water and brine, dried over anhydrous sodium sulfate, filtered, and concentrated under reduced pressure. The residue was purified by column chromatography on silica gel eluted with a petroleum ether/ acetone (9:1) mixture to afford the desired product 65 with $85 \%$ yield. Pale-yellow oil; $R_{f}=0.48$ (petroleum ether/acetone $85: 15$ ). ${ }^{1} \mathrm{H}$ $\operatorname{NMR}\left(400 \mathrm{MHz}, \mathrm{CDCl}_{3}\right) \delta_{\mathrm{H}} 6.66(\mathrm{~s}, 1 \mathrm{H}), 6.61(\mathrm{~s}, 1 \mathrm{H}), 5.75(\mathrm{t}, J=$ $7.4 \mathrm{~Hz}, 1 \mathrm{H}), 5.14-5.09(\mathrm{~m}, 2 \mathrm{H}), 4.64(\mathrm{~s}, 2 \mathrm{H}), 4.55(\mathrm{~s}, 2 \mathrm{H}), 2.75-$ $2.71(\mathrm{~m}, 2 \mathrm{H}), 2.26-2.21(\mathrm{~m}, 2 \mathrm{H}), 2.25(\mathrm{~s}, 3 \mathrm{H}), 2.14-2.01(\mathrm{~m}, 7 \mathrm{H})$, $2.12(\mathrm{~s}, 3 \mathrm{H}), 2.05(\mathrm{~s}, 6 \mathrm{H}), 1.98-1.94(\mathrm{~m}, 2 \mathrm{H}), 1.83-1.70(\mathrm{~m}, 4 \mathrm{H})$, $1.66-1.53(\mathrm{~m}, 2 \mathrm{H}), 1.58(\mathrm{~s}, 3 \mathrm{H}), 1.27(\mathrm{~s}, 3 \mathrm{H}) .{ }^{13} \mathrm{C}$ NMR $(100 \mathrm{MHz}$, $\left.\mathrm{CDCl}_{3}\right) \delta_{\mathrm{C}} 171.6,170.9,170.5,149.8,142.6,136.5,135.3,133.9$, $129.1,127.5,125.3,124.3,121.3,121.0,119.2,76.0,66.8,59.9,40.0$, $39.7,39.1,31.0,26.7,26.3,24.2,22.5,22.2,21.2,21.1$ (2C), 16.3, 16.0 (2C). IR (ATR) $\nu_{\max } 2924,2853,1739,1475,1368,1204,1020,801$ $\mathrm{cm}^{-1}$. MS (EI) $m / z$ calcd for $\mathrm{C}_{33} \mathrm{H}_{46} \mathrm{O}_{7}\left[\mathrm{M}^{+\bullet}\right]$ 554.3, found 554.5.

2-(11-((R)-6-Acetoxy-2,8-dimethylchroman-2-yl)-4,8dimethylundecyl)propane-1,3-diyl Diacetate (66). To a solution of $65(140 \mathrm{mg}, 0.25 \mathrm{mmol}, 1$ equiv $)$ in ethyl acetate $(10 \mathrm{~mL})$ was added under a nitrogen atmosphere palladium over charcoal (loading $10 \mathrm{wt}$ $\%)$, and then, hydrogen was bubbled in the organic phase. The reaction mixture was stirred at room temperature for $40 \mathrm{~min}$ under a hydrogen atmosphere. Completion of the reaction was monitored by ${ }^{1} \mathrm{H}$ NMR. The resulting mixture was filtered on Celite, washed with ethyl acetate, and concentrated under reduced pressure. The residue was purified by column chromatography on silica gel eluted with a petroleum ether/acetone (95:5) mixture to afford the desired product 66 as a diastereomeric mixture with $52 \%$ yield. Pale-yellow oil; $R_{f}=$ 0.50 (petroleum ether/acetone 8:2). ${ }^{1} \mathrm{H} \mathrm{NMR}\left(400 \mathrm{MHz}, \mathrm{CDCl}_{3}\right) \delta_{\mathrm{H}}$ $6.66(\mathrm{~s}, 1 \mathrm{H}), 6.60(\mathrm{~s}, 1 \mathrm{H}), 4.04(\mathrm{qd}, J=5.8,11.1 \mathrm{~Hz}, 4 \mathrm{H}), 2.74-2.67$ $(\mathrm{m}, 2 \mathrm{H}), 2.25(\mathrm{~s}, 3 \mathrm{H}), 2.13(\mathrm{~s}, 3 \mathrm{H}), 2.05(\mathrm{~s}, 6 \mathrm{H}), 2.01-1.97(\mathrm{~m}, 1 \mathrm{H})$, $1.83-1.68(\mathrm{~m}, 2 \mathrm{H}), 1.60-1.50(\mathrm{~m}, 2 \mathrm{H}), 1.44-1.28(\mathrm{~m}, 10 \mathrm{H}), 1.25$ $(\mathrm{s}, 6 \mathrm{H}), 1.16-0.99(\mathrm{~m}, 5 \mathrm{H}), 0.85-0.83(\mathrm{~m}, 6 \mathrm{H}) .{ }^{13} \mathrm{C}$ NMR $(100$ $\left.\mathrm{MHz}, \mathrm{CDCl}_{3}\right) \delta_{\mathrm{C}} 171.3(2 \mathrm{C}), 170.5,149.9,142.5,127.4,121.2,121.0$, $119.2,76.2,64.5,64.4,40.3$ (2C), 37.6-37.2 (7C), 32.8 (2C), 31.0 (2C), 28.6, 24.6, 24.4, 22.6, 21.2, 21.1, 21.0 (2C), 19.8-19.7 (4C), 16.3. MS (EI) $m / z$ calcd for $\mathrm{C}_{33} \mathrm{H}_{52} \mathrm{O}_{7}\left[\mathrm{M}^{+\bullet}\right] 560.4$, found 560.5 .

2-(11-((R)-6-Hydroxy-2,8-dimethylchroman-2-yl)-4, 8dimethylundecyl)propane-1,3-diol (26). To a solution of 66 (43 mg, $0.08 \mathrm{mmol}, 1$ equiv) in methanol $(3 \mathrm{~mL})$ was added under a nitrogen atmosphere a solution of $\mathrm{MeONa} 0.1 \mathrm{M}(2.33 \mathrm{~mL}, 0.23 \mathrm{mmol}, 3$ equiv). The reaction mixture was stirred at room temperature for 40 min under a nitrogen atmosphere. Then, the reaction was quenched with an aqueous solution of hydrochloric acid $(1 \mathrm{M})$. The resulting mixture was extracted three times with dichloromethane. The combined organic layers were washed with water and brine, dried over anhydrous sodium sulfate, filtered, and concentrated under reduced pressure to afford the desired product $\mathbf{2 6}$ with $99 \%$ yield. Pale-yellow oil; $R_{f}=0.15$ (petroleum ether/acetone 85:15). ${ }^{1} \mathrm{H}$ NMR $\left(400 \mathrm{MHz}, \mathrm{CDCl}_{3}\right) \delta_{\mathrm{H}} 6.47(\mathrm{~s}, 1 \mathrm{H}), 6.38(\mathrm{~s}, 1 \mathrm{H}), 3.85-3.83(\mathrm{~m}$, $2 \mathrm{H}), 3.69-3.65(\mathrm{~m}, 2 \mathrm{H}), 2.94(\mathrm{bs}, 2 \mathrm{H}, \mathrm{OH}), 2.70-2.65(\mathrm{~m}, 2 \mathrm{H})$, $2.11(\mathrm{~s}, 3 \mathrm{H}), 1.80-1.70(\mathrm{~m}, 3 \mathrm{H}), 1.56-1.52(\mathrm{~m}, 1 \mathrm{H}), 1.45-1.15(\mathrm{~m}$, $19 \mathrm{H}), 1.14-1.00(\mathrm{~m}, 4 \mathrm{H}), 0.84-0.83(\mathrm{~m}, 6 \mathrm{H}) .{ }^{13} \mathrm{C}$ NMR $(100 \mathrm{MHz}$, $\left.\mathrm{CDCl}_{3}\right) \delta_{\mathrm{C}} 148.1,145.9,127.3,121.4,115.8,112.7,75.6(3 \mathrm{C}), 66.7$ (2C), 41.9, 39.5 (4C), 37.5-37.1 (9C), 32.8-32.5 (6C), 31.5-31.4 
(4C), 29.8, 28.1, 24.8 (2C), 24.6-24.3 (6C), 22.6, 21.1-20.8 (4C), 20.0-19.8 (5C), 16.2. IR (ATR) $\nu_{\max } 3361,2925,2855,1466,1377$, $1220,1032,855 \mathrm{~cm}^{-1}$. HRMS (ESI) $\mathrm{m} / z$ calcd for $\mathrm{C}_{27} \mathrm{H}_{45} \mathrm{O}_{4}[\mathrm{M}-$ $\mathrm{H}]^{-}$433.3318, found 433.3313 .

2-((4E,8E)-11-((R)-6-Hydroxy-2,8-dimethyl-5,7-bis((4-methylpiperazin-1-yl)methyl)chroman-2-yl)-4,8-dimethylundeca-4,8-dien1-ylidene)propane-1,3-diol (40). To a solution of $27 \mathrm{~d}$ (100 mg, 0.24 mmol, 1 equiv) in methanol $(5 \mathrm{~mL})$ under a nitrogen atmosphere was added the Mannich alkylating reagent $(4.8 \mathrm{mmol}, 20$ equiv), freshly prepared from paraformaldehyde and $\mathrm{N}$-methylpiperazine $(547 \mathrm{mg}$, $4.8 \mathrm{mmol}, 20$ equiv). The reaction mixture was refluxed for $48 \mathrm{~h}$. Then, the solvent was evaporated under reduced pressure. The crude residue was diluted into methyl-tert-butyl ether (MTBE). The organic layer was stirred for $30 \mathrm{~min}$ with an aqueous saturated solution of sodium phosphate and washed with water $(3 \times 20 \mathrm{~mL})$ and brine. It was then dried over anhydrous sodium sulfate and filtered. Removal of the solvent under reduced pressure led to the final bis-Mannich base characterized without further purification ( $92 \%$ yield). $R_{f}$ (neutral $\left.\mathrm{Al}_{2} \mathrm{O}_{3}\right)=0.35\left(\mathrm{DCM} / \mathrm{MeOH}\right.$ 9.5/0.5). ${ }^{1} \mathrm{H}$ NMR $(500 \mathrm{MHz}$, methanol- $\left.d_{4}\right) \delta_{\mathrm{H}} 5.55(\mathrm{t}, J=7.2 \mathrm{~Hz}, 1 \mathrm{H}), 5.14(\mathrm{t}, J=7.2 \mathrm{~Hz}, 1 \mathrm{H})$, $5.12(\mathrm{t}, J=7.2 \mathrm{~Hz}, 1 \mathrm{H}), 4.15(\mathrm{~s}, 2 \mathrm{H}), 4.08(\mathrm{~s}, 2 \mathrm{H}), 3.65(\mathrm{~s}, 2 \mathrm{H}), 3.60$ $(\mathrm{s}, 2 \mathrm{H}), 2.74(\mathrm{t}, J=5.9 \mathrm{~Hz}, 2 \mathrm{H}), 2.67-2.35(\mathrm{~m}, 16 \mathrm{H}), 2.29(\mathrm{~s}, 6 \mathrm{H})$, 2.24-2.19 (m, 2H), $2.13(\mathrm{~s}, 3 \mathrm{H}), 2.12-2.09(\mathrm{~m}, 2 \mathrm{H}), 2.07-2.05(\mathrm{~m}$, $2 \mathrm{H}), 2.04-1.96(\mathrm{~m}, 4 \mathrm{H}), 1.83-1.72(\mathrm{~m}, 2 \mathrm{H}), 1.59(\mathrm{~s}, 3 \mathrm{H}), 1.52(\mathrm{~s}$, $3 \mathrm{H}), 1.62-1.47(\mathrm{~m}, 2 \mathrm{H}), 1.24(\mathrm{~s}, 3 \mathrm{H}) .{ }^{13} \mathrm{C}$ NMR $(125 \mathrm{MHz}$, methanol- $\left.d_{4}\right) \delta_{\mathrm{C}} 151.7,145.8,139.3,135.9,135.5,130.7,126.5,125.8$, 125.7, 121.3, 121.1, 118.5, 75.5, 65.6, 58.3, 55.8, 55.9 (2C), 55.5, 54.8, 53.0, 53.1 (2C), 45.9 (2C), 40.5, 40.3, 40.2, 32.7, 27.6, 27.1, 24.3, 22.3, 21.2, 16.0, 16.1, 12.0. HRMS (FAB) $m / z$ calcd for $\mathrm{C}_{33} \mathrm{H}_{44} \mathrm{O}_{6}[\mathrm{M}$ $+\mathrm{H}]^{+}$653.5000, found 653.4992 .

2-((4E,8E)-11-((R)-6-Hydroxy-2,8-dimethyl-5-(pyrrolidin-1ylmethyl)chroman-2-yl)-4,8-dimethylundeca-4,8-dien-1-ylidene)propane-1,3-diol (35). To a solution of $27 \mathrm{~d}(100 \mathrm{mg}, 0.24 \mathrm{mmol}, 1$ equiv) in methanol $(5 \mathrm{~mL})$ under a nitrogen atmosphere, we added pyrrolidine ( $41 \mathrm{mg}, 0.48 \mathrm{mmol}, 2$ equiv), either $N, N, N, N$-tetramethylmethylene diamine (TMMDA) or the iminium freshly prepared from paraformaldehyde and the corresponding secondary amine. The reaction mixture was refluxed for $5 \mathrm{~h}$. Then, the solvent was evaporated under reduced pressure. The crude residue was diluted into methyl-tert-butyl ether (MTBE). The organic layer was stirred for 30 min with an aqueous saturated solution of sodium phosphate and washed with water $(3 \times 20 \mathrm{~mL})$ and brine. It was then dried over anhydrous sodium sulfate and filtered. Removal of the solvent under reduced pressure led to the final Mannich base 35 with $90 \%$ yield characterized without further purification. $R_{f}$ (neutral $\mathrm{Al}_{2} \mathrm{O}_{3}$ ) $=0.35$ (DCM/petroleum ether/MeOH 5:5:0.3). ${ }^{1} \mathrm{H}$ NMR $(500 \mathrm{MHz}$, acetone- $\left.d_{6}\right) \delta_{\mathrm{H}} 6.39(\mathrm{~s}, 1 \mathrm{H}), 5.47(\mathrm{t}, J=7.2 \mathrm{~Hz}, 1 \mathrm{H}), 5.16(\mathrm{t}, J=7.2$ $\mathrm{Hz}, 1 \mathrm{H}), 5.12(\mathrm{t}, J=7.2 \mathrm{~Hz}, 1 \mathrm{H}), 4.17(\mathrm{~s}, 2 \mathrm{H}), 4.10(\mathrm{~s}, 2 \mathrm{H}), 3.66(\mathrm{t}, J$ $=3.9 \mathrm{~Hz}, 4 \mathrm{H}), 3.78(\mathrm{~s}, 2 \mathrm{H}), 2.67(\mathrm{t}, J=6.8 \mathrm{~Hz}, 2 \mathrm{H}), 2.63(\mathrm{t}, J=5.0$ $\mathrm{Hz}, 4 \mathrm{H}), 2.22(\mathrm{~s}, 3 \mathrm{H}), 2.20-2.11(\mathrm{~m}, 4 \mathrm{H}), 2.09-2.06(\mathrm{~m}, 2 \mathrm{H}), 2.07$ $(\mathrm{s}, 3 \mathrm{H}), 2.01-1.96(\mathrm{~m}, 4 \mathrm{H}), 1.85-1.71(\mathrm{~m}, 4 \mathrm{H}), 1.63-1.49(\mathrm{~m}, 8 \mathrm{H})$, $1.23(\mathrm{~s}, 3 \mathrm{H}) .{ }^{13} \mathrm{C}$ NMR $\left(125 \mathrm{MHz}\right.$, acetone- $\left.d_{6}\right) \delta_{\mathrm{C}} 151.7,145.1,140.2$, $135.5,135.3,127.8,126.2,125.4,125.2,119.2,118.0,117.0,74.7$, 65.9, 58.9, 54.2 (2C), 54.1, 46.1, 40.5, 40.3, 39.7, 32.3, 27.2, 26.7, 24.2, 24.1, 22.8, 21.1, 16.3, 16.1, 15.9. HRMS (FAB) $\mathrm{m} / z$ calcd for $\mathrm{C}_{32} \mathrm{H}_{50} \mathrm{NO}_{4}[\mathrm{M}+\mathrm{H}]^{+}$512.3735, found 512.3758.

2-((4E,8E)-11-((R)-5-((Dimethylamino)methyl)-6-hydroxy-2,8-dimethylchroman-2-yl)-4,8-dimethylundeca-4,8-dien-1-ylidene)propane-1,3-diol (36). 36 was obtained from $27 \mathrm{~d}$ (100 mg, 0.24 mmol, 1 equiv), paraformaldehyde, and TMMDA ( $68 \mu \mathrm{L}, 0.48 \mathrm{mmol}$, 2 equiv) with $90 \%$ yield using the same method as described above for 35. $R_{f}$ (neutral $\left.\mathrm{Al}_{2} \mathrm{O}_{3}\right)=0.40(\mathrm{DCM} /$ petroleum ether $/ \mathrm{MeOH}$ 5:5:0.3). ${ }^{1} \mathrm{H}$ NMR $\left(500 \mathrm{MHz}\right.$, acetone- $\left.d_{6}\right) \delta_{\mathrm{H}} 6.39(\mathrm{~s}, 1 \mathrm{H}), 5.47(\mathrm{t}, J$ $=7.2 \mathrm{~Hz}, 1 \mathrm{H}), 5.16(\mathrm{t}, J=7.2 \mathrm{~Hz}, 1 \mathrm{H}), 5.13(\mathrm{t}, J=7.2 \mathrm{~Hz}, 1 \mathrm{H}), 4.17$ $(\mathrm{s}, 2 \mathrm{H}), 4.10(\mathrm{~s}, 2 \mathrm{H}), 3.57(\mathrm{~s}, 2 \mathrm{H}), 2.67(\mathrm{t}, J=6.8 \mathrm{~Hz}, 2 \mathrm{H}), 2.29(\mathrm{~s}$, $6 \mathrm{H}), 2.22(\mathrm{~s}, 3 \mathrm{H}), 2.20-2.11(\mathrm{~m}, 4 \mathrm{H}), 2.09-2.06(\mathrm{~m}, 2 \mathrm{H}), 2.07(\mathrm{~s}$, $3 \mathrm{H}), 2.01-1.96(\mathrm{~m}, 4 \mathrm{H}), 1.85-1.71(\mathrm{~m}, 2 \mathrm{H}), 1.63-1.49(\mathrm{~m}, 2 \mathrm{H})$, $1.59(\mathrm{~s}, 6 \mathrm{H}), 1.23(\mathrm{~s}, 3 \mathrm{H}) .{ }^{13} \mathrm{C}$ NMR $\left(125 \mathrm{MHz}\right.$, acetone- $\left.d_{6}\right) \delta_{\mathrm{C}}$ $151.7,145.1,140.2,135.5,135.3,127.8,126.3,125.4,125.2,119.7$, 117.7, 117.0, 74.7, 66.9, 58.9, 58.2, 44.6 (2C), 40.5, 40.3, 39.7, 32.3,
27.2, 26.7, 24.1, 22.8, 21.1, 16.3, 16.1, 15.9. HRMS (FAB) $\mathrm{m} / z$ calcd for $\mathrm{C}_{30} \mathrm{H}_{48} \mathrm{NO}_{4}[\mathrm{M}+\mathrm{H}]^{+}$486.3577, found 486.3567 .

2-((4E,8E)- $11-((R)-6-$ Hydroxy-2,8-dime th yl-5(morpholinomethyl)chroman-2-yl)-4,8-dimethylundeca-4,8-dien1-ylidene)propane-1,3-diol (37). 37 was obtained from $27 \mathrm{~d}(100 \mathrm{mg}$, $0.24 \mathrm{mmol}, 1$ equiv), paraformaldehyde, and morpholine ( $49 \mathrm{mg}, 0.48$ mmol, 2 equiv) with $95 \%$ yield using the same method as described above for 35. $R_{f}$ (neutral $\left.\mathrm{Al}_{2} \mathrm{O}_{3}\right)=0.40(\mathrm{DCM} /$ petroleum ether/ MeOH 5:4:1). ${ }^{1} \mathrm{H}$ NMR (500 MHz, acetone- $\left.d_{6}\right) \delta_{\mathrm{H}} 6.41(\mathrm{~s}, 1 \mathrm{H}), 5.47$ $(\mathrm{t}, J=7.2 \mathrm{~Hz}, 1 \mathrm{H}), 5.16(\mathrm{t}, J=7.2 \mathrm{~Hz}, 1 \mathrm{H}), 5.12(\mathrm{t}, J=7.2 \mathrm{~Hz}, 1 \mathrm{H})$, $4.17(\mathrm{~s}, 2 \mathrm{H}), 4.10(\mathrm{~s}, 2 \mathrm{H}), 3.66(\mathrm{t}, J=3.9 \mathrm{~Hz}, 4 \mathrm{H}), 3.65(\mathrm{~s}, 2 \mathrm{H}), 2.67$ $(\mathrm{t}, J=6.8 \mathrm{~Hz}, 2 \mathrm{H}), 2.52(\mathrm{~s}, 4 \mathrm{H}), 2.22(\mathrm{~s}, 3 \mathrm{H}), 2.20-2.11(\mathrm{~m}, 4 \mathrm{H})$, 2.09-2.06 (m, 2H), $2.07(\mathrm{~s}, 3 \mathrm{H}), 2.01-1.96(\mathrm{~m}, 4 \mathrm{H}), 1.85-1.71(\mathrm{~m}$, $2 \mathrm{H}), 1.63-1.49(\mathrm{~m}, 2 \mathrm{H}), 1.59(\mathrm{~s}, 6 \mathrm{H}), 1.23(\mathrm{~s}, 3 \mathrm{H}) .{ }^{13} \mathrm{C}$ NMR $(125$ $\mathrm{MHz}$, acetone- $\left.d_{6}\right) \delta_{\mathrm{C}} 151.3,145.4,140.2,135.5,135.3,127.8,126.4$, $125.5,125.2,120.0,117.0,116.7,74.7,67.3$ (2C), 65.9, 58.9, 56.9, 53.6 (2C), 46.1, 40.5, 40.3, 39.7, 32.3, 27.2, 26.7, 24.2, 22.8, 21.1, $16.3,16.1,15.9$. HRMS (FAB) $m / z$ calcd for $\mathrm{C}_{32} \mathrm{H}_{50} \mathrm{NO}_{5}[\mathrm{M}+\mathrm{H}]^{+}$ 528.3684 , found 528.3675 .

2-((4E, 8E)-11-((R)-6-Hydroxy-2,8-dimethyl-5-(piperidin-1ylmethyl)chroman-2-yl)-4,8-dimethylundeca-4,8-dien-1-ylidene)propane-1,3-diol (38). 38 was obtained from $27 \mathrm{~d}$ (100 mg, 0.24 mmol, 1 equiv), paraformaldehyde, and piperidine ( $47 \mathrm{mg}, 0.48$ mmol, 2 equiv) with $95 \%$ yield using the same method as described above for 35. $R_{f}$ (neutral $\left.\mathrm{Al}_{2} \mathrm{O}_{3}\right)=0.35(\mathrm{DCM} /$ petroleum ether/ $\mathrm{MeOH} 5: 4: 1) .{ }^{1} \mathrm{H}$ NMR ( $500 \mathrm{MHz}$, acetone- $\left.d_{6}\right) \delta_{\mathrm{H}} 6.38(\mathrm{~s}, 1 \mathrm{H}), 5.47$ $(\mathrm{t}, J=7.2 \mathrm{~Hz}, 1 \mathrm{H}), 5.16(\mathrm{t}, J=7.2 \mathrm{~Hz}, 1 \mathrm{H}), 5.12(\mathrm{t}, J=7.2 \mathrm{~Hz}, 1 \mathrm{H})$, $4.17(\mathrm{~s}, 2 \mathrm{H}), 4.10(\mathrm{~s}, 2 \mathrm{H}), 3.60(\mathrm{~s}, 2 \mathrm{H}), 2.64(\mathrm{t}, J=6.8 \mathrm{~Hz}, 2 \mathrm{H})$, $2.58-2.39(\mathrm{~m}, 4 \mathrm{H}), 2.22(\mathrm{~s}, 3 \mathrm{H}), 2.20-2.11(\mathrm{~m}, 4 \mathrm{H}), 2.09-2.06(\mathrm{~m}$, $2 \mathrm{H}), 2.07(\mathrm{~s}, 3 \mathrm{H}), 2.01-1.96(\mathrm{~m}, 4 \mathrm{H}), 1.85-1.71(\mathrm{~m}, 2 \mathrm{H}), 1.63-$ $1.43(\mathrm{~m}, 14 \mathrm{H}), 1.23(\mathrm{~s}, 3 \mathrm{H}) .{ }^{13} \mathrm{C}$ NMR $\left(125 \mathrm{MHz}\right.$, acetone- $\left.d_{6}\right) \delta_{\mathrm{C}}$ $151.8,145.2$, 140.2, 135.5, 135.3, 127.8, 126.2, 125.5, 125.2, 119.7, $117.0,117.2,74.7,66.0,58.9,57.5,54.4(2 \mathrm{C}), 46.1,40.5,40.3,39.7$, 32.3, 27.2, 26.8, 26.7 (2C), 24.8, 24.2, 22.8, 21.0, 16.3, 16.1, 15.9. HRMS (FAB) $\mathrm{m} / z$ calcd for $\mathrm{C}_{33} \mathrm{H}_{51} \mathrm{NO}_{4}\left[\mathrm{M}^{+\bullet}\right] 525.3818$, found 525.3817.

2-((4E,8E)-11-((R)-6-Hydroxy-2,8-dimethyl-5-((4-methylpiperazin-1-yl)methyl)chroman-2-yl)-4,8-dimethylundeca-4,8-dien-1ylidene)propane-1,3-diol (39). 39 was obtained from $27 \mathbf{d}(100 \mathrm{mg}$, $0.24 \mathrm{mmol}, 1$ equiv), paraformaldehyde, and $\mathrm{N}$-methylpiperazine (55 $\mathrm{mg}, 0.48 \mathrm{mmol}, 2$ equiv) with $92 \%$ yield using the same method as described above for 35. $R_{f}$ (neutral $\left.\mathrm{Al}_{2} \mathrm{O}_{3}\right)=0.35(\mathrm{DCM} /$ petroleum ether/MeOH 5:4.5:0.5). ${ }^{1} \mathrm{H}$ NMR $\left(500 \mathrm{MHz}\right.$, acetone- $\left.d_{6}\right) \delta_{\mathrm{H}} 6.39(\mathrm{~s}$, $1 \mathrm{H}), 5.47(\mathrm{t}, J=7.2 \mathrm{~Hz}, 1 \mathrm{H}), 5.15(\mathrm{t}, J=7.2 \mathrm{~Hz}, 1 \mathrm{H}), 5.12(\mathrm{t}, J=7.2$ $\mathrm{Hz}, 1 \mathrm{H}), 4.17(\mathrm{~s}, 2 \mathrm{H}), 4.10(\mathrm{~s}, 2 \mathrm{H}), 3.63(\mathrm{~s}, 2 \mathrm{H}), 2.65(\mathrm{t}, J=6.8 \mathrm{~Hz}$, $2 \mathrm{H}), 2.55-2.25(\mathrm{~m}, 8 \mathrm{H}), 2.22(\mathrm{~s}, 3 \mathrm{H}), 2.20-2.11(\mathrm{~m}, 4 \mathrm{H}), 2.09-$ $2.06(\mathrm{~m}, 2 \mathrm{H}), 2.07(\mathrm{~s}, 3 \mathrm{H}), 2.01-1.96(\mathrm{~m}, 4 \mathrm{H}), 1.85-1.71(\mathrm{~m}, 2 \mathrm{H})$, $1.63-1.49(\mathrm{~m}, 2 \mathrm{H}), 1.59(\mathrm{~s}, 6 \mathrm{H}), 1.23(\mathrm{~s}, 3 \mathrm{H}) .{ }^{13} \mathrm{C}$ NMR $(125 \mathrm{MHz}$, acetone- $\left.d_{6}\right) \delta_{\mathrm{C}} 151.5,145.2,140.2,135.4,135.3,127.6,126.4,125.5$, $125.2,119.8,117.0(2 \mathrm{C}), 74.7,65.9,58.9,56.7,55.8(2 \mathrm{C}), 53.1(2 \mathrm{C})$ 46.1, 40.5, 40.3, 39.7, 32.3, 27.2, 26.7, 24.1, 22.8, 21.1, 16.3, 16.1, 15.9. HRMS (FAB) $m / z$ calcd for $\mathrm{C}_{33} \mathrm{H}_{52} \mathrm{~N}_{2} \mathrm{O}_{4}[\mathrm{M}+\mathrm{H}]^{+}$541.3999, found 541.3992 .

(R)-3-Acetyl-7-((3E, 7E)-13-hydroxy-12-(hydroxymethyl)-4,8-dimethyltrideca-3,7,11-trien-1-yl)-5,7,10-trimethyl-8,9dihydropyrano[2,3-g]chromen-2(7H)-one (41). To a solution of aldehyde 33 (0.11 mmol, 1 equiv) in ethanol $(3 \mathrm{~mL})$, piperidine (11 $\mu \mathrm{L}, 0.11 \mathrm{mmol}, 1$ equiv) and ethyl acetoacetate $(17 \mu \mathrm{L}, 0.132 \mathrm{mmol}$, 1.2 equiv) were added. The reaction mixture was refluxed until completion of the reaction monitored by TLC. After cooling to room temperature, the reaction mixture was diluted with ether. The organic layer was washed with water to $\mathrm{pH} 7$ and brine, dried over anhydrous sodium sulfate, filtered, and concentrated under reduced pressure. The crude residue was purified by silica preparative TLC to yield the corresponding coumarine $\mathbf{4 1}$ with $89 \%$ yield. $R_{f}=0.35$ (petroleum ether/DCM/acetone 5:3:2). ${ }^{1} \mathrm{H}$ NMR $\left(500 \mathrm{MHz}\right.$, acetone- $\left.d_{6}\right) \delta_{\mathrm{H}}$ $8.64(\mathrm{~s}, 1 \mathrm{H}), 5.47(\mathrm{t}, J=7.2 \mathrm{~Hz}, 1 \mathrm{H}), 5.18(\mathrm{t}, J=7.2 \mathrm{~Hz}, 1 \mathrm{H}), 5.13(\mathrm{t}$ $J=7.2 \mathrm{~Hz}, 1 \mathrm{H}), 4.16(\mathrm{~d}, J=4.8 \mathrm{~Hz}, 2 \mathrm{H}), 4.09(\mathrm{~d}, J=4.8 \mathrm{~Hz}, 2 \mathrm{H})$, $3.67(\mathrm{t}, J=5.3 \mathrm{~Hz}, 1 \mathrm{H}), 3.59(\mathrm{t}, J=5.3 \mathrm{~Hz}, 1 \mathrm{H}), 2.85(\mathrm{t}, J=7.0 \mathrm{~Hz}$ $2 \mathrm{H}), 2.61(\mathrm{~s}, 3 \mathrm{H}), 2.41(\mathrm{~s}, 3 \mathrm{H}), 2.29(\mathrm{~s}, 3 \mathrm{H}), 2.23-2.14(\mathrm{~m}, 4 \mathrm{H})$, 2.11-2.06 (m, 2H), 2.01-1.96 (m, 4H), 1.96-1.81 (m, $2 \mathrm{H}), 1.73-$ 
$1.63(\mathrm{~m}, 2 \mathrm{H}), 1.58(\mathrm{~s}, 3 \mathrm{H}), 1.61(\mathrm{~s}, 3 \mathrm{H}), 1.33(\mathrm{~s}, 3 \mathrm{H}) .{ }^{13} \mathrm{C} \mathrm{NMR}$ $\left(125 \mathrm{MHz}\right.$, acetone- $\left.d_{6}\right) \delta_{\mathrm{C}} 195.7,159.7,149.0,148.2,145.1,140.2$, $135.7,135.3,129.6,127.7,125.2,125.1,123.6,122.9,122.0,116.7$, $76.9,65.9,58.9,40.4,40.3,39.9,31.5,30.4,27.2,26.6,24.1,22.8$, 22.1, 16.1, 16.0, 10.8, 10.6. IR (ATR) $\nu_{\max } 3364,2925,2855,1726$, 1550, $1232 \mathrm{~cm}^{-1}$. HRMS (FAB) $\mathrm{m} / z$ calcd for $\mathrm{C}_{33} \mathrm{H}_{44} \mathrm{O}_{6}\left[\mathrm{M}^{+\bullet}\right]$ 536.3138 , found 536.3133 .

(R)-2-Acetyl-8-((3E,7E)-13-hydroxy-12-(hydroxymethyl)-4,8-dimethyltrideca-3,7,11-trien-1-yl)-6,8-dimethyl-9, 10-dihydropyrano[3,2-f]chromen-3(8H)-one (42). 42 was obtained from 34 with $93 \%$ yield using the same method as described above for 41. $R_{f}=0.35$ (petroleum ether/DCM/acetone 5:3:2). ${ }^{1} \mathrm{H}$ NMR (500 MHz, acetone- $\left.d_{6}\right) \delta_{\mathrm{H}} 8.57(\mathrm{~s}, 1 \mathrm{H}), 7.08(\mathrm{~s}, 1 \mathrm{H}), 5.47(\mathrm{t}, J=7.2 \mathrm{~Hz}, 1 \mathrm{H})$, $5.18(\mathrm{t}, J=7.2 \mathrm{~Hz}, 1 \mathrm{H}), 5.13(\mathrm{t}, J=7.2 \mathrm{~Hz}, 1 \mathrm{H}), 4.16(\mathrm{~d}, J=4.8 \mathrm{~Hz}$, $2 \mathrm{H}), 4.09(\mathrm{~d}, J=4.8 \mathrm{~Hz}, 2 \mathrm{H}), 3.66(\mathrm{t}, J=5.3 \mathrm{~Hz}, 1 \mathrm{H}), 3.57(\mathrm{t}, J=5.3$ $\mathrm{Hz}, 1 \mathrm{H}), 3.09-3.06(\mathrm{~m}, 2 \mathrm{H}), 2.60 .(\mathrm{s}, 3 \mathrm{H}), 2.30(\mathrm{~s}, 3 \mathrm{H}), 2.23-2.14$ (m, 4H), 2.11-2.06 (m, 2H), 2.01-1.96 (m, 4H), 1.96-1.81 (m, $2 \mathrm{H}), 1.73-1.63(\mathrm{~m}, 2 \mathrm{H}), 1.61(\mathrm{~s}, 3 \mathrm{H}), 1.58(\mathrm{~s}, 3 \mathrm{H}), 1.35(\mathrm{~s}, 3 \mathrm{H}) .{ }^{13} \mathrm{C}$ NMR $\left(125 \mathrm{MHz}\right.$, acetone- $\left.d_{6}\right) \delta_{\mathrm{C}} 196.7,159.8,150.7,149.4,144.0$, 140.2 , 136.0, 135.7, 135.3, 127.7, 125.2, 125.1, 123.6, 119.1, 116.6, 116.0, 77.0, 65.9, 58.9, 40.5, 40.4, 39.9, 31.5, 30.4, 27.2, 26.6, 23.9, $22.8,19.5,17.2,16.1,16.0$. HRMS (ESI) $\mathrm{m} / z$ calcd for $\mathrm{C}_{32} \mathrm{H}_{42} \mathrm{NaO}_{6}$ $[\mathrm{M}+\mathrm{Na}]^{+} 545.2874$, found 545.2870 .

Ethyl-(R)-8-((3E,7E)-13-hydroxy-12-(hydroxymethyl)-4,8-dimethyltrideca-3,7,11-trien-1-yl)-6,8-dimethyl-3-oxo-3,8,9,10tetrahydropyrano[3,2-f]chromene-2-carboxylate (43). 43 was obtained from 34 and diethyl malonate with $90 \%$ yield using the same method as described above for 41. $R_{f}=0.30$ (petroleum ether/ DCM/acetone, 5:3:2). ${ }^{1} \mathrm{H}$ NMR $\left(500 \mathrm{MHz}\right.$, acetone- $\left.d_{6}\right) \delta_{\mathrm{H}} 8.63(\mathrm{~s}$, $1 \mathrm{H}), 7.05(\mathrm{~s}, 1 \mathrm{H}), 5.45(\mathrm{t}, J=7.2 \mathrm{~Hz}, 1 \mathrm{H}), 5.18(\mathrm{t}, J=7.2 \mathrm{~Hz}, 1 \mathrm{H})$, $5.13(\mathrm{t}, J=7.2 \mathrm{~Hz}, 1 \mathrm{H}), 4.31(\mathrm{q}, J=7.1 \mathrm{~Hz}, 2 \mathrm{H}), 4.16(\mathrm{~d}, J=4.8 \mathrm{~Hz}$, $2 \mathrm{H}), 4.09(\mathrm{~d}, J=4.8 \mathrm{~Hz}, 2 \mathrm{H}), 3.71(\mathrm{t}, J=5.3 \mathrm{~Hz}, 1 \mathrm{H}), 3.63(\mathrm{t}, J=5.3$ $\mathrm{Hz}, 1 \mathrm{H}), 3.06(\mathrm{t}, J=6.3 \mathrm{~Hz}, 2 \mathrm{H}), 2.30(\mathrm{~s}, 3 \mathrm{H}), 2.23-2.14(\mathrm{~m}, 4 \mathrm{H})$, 2.11-2.06 (m, $2 \mathrm{H}), 2.01-1.96(\mathrm{~m}, 4 \mathrm{H}), 1.96-1.81(\mathrm{~m}, 2 \mathrm{H}), 1.73-$ $1.63(\mathrm{~m}, 2 \mathrm{H}), 1.61(\mathrm{~s}, 3 \mathrm{H}), 1.58(\mathrm{~s}, 3 \mathrm{H}), 1.36(\mathrm{t}, J=7.1 \mathrm{~Hz}, 3 \mathrm{H})$, $1.35(\mathrm{~s}, 3 \mathrm{H}) .{ }^{13} \mathrm{C}$ NMR $\left(125 \mathrm{MHz}\right.$, acetone- $\left.d_{6}\right) \delta_{\mathrm{C}} 164.2,156.9$, $150.7,149.4,145.2,140.2,136.5,135.7,135.3,127.7,125.2,125.1$, 118.6, 117.4, 116.6, 115.4, 76.9, 65.9, 61.9, 58.9, 40.5, 40.4, 39.9, 31.0, 27.2, 26.6, 23.9, 22.8, 19.4, 17.2, 16.1, 15.9, 14.5. HRMS (ESI) $\mathrm{m} / \mathrm{z}$ calcd for $\mathrm{C}_{33} \mathrm{H}_{44} \mathrm{NaO}_{7}[\mathrm{M}+\mathrm{Na}]^{+}$575.2979, found 575.2969.

Ethyl-4-(((2R)-2-((3E,7E)-11-(2-(3,4-dimethoxyphenyl)-1,3-dioxan-5-ylidene)-4,8-dimethylundeca-3,7-dien-1-yl)-2,8-dimethylchroman-6-yl)oxy)butanoate (67). Under a nitrogen atmosphere, a solution of 44 ( 1 equiv) in dry THF $(0.05 \mathrm{M})$ was added dropwise to a suspension of sodium hydride (60\% wt, 3 equiv) in $2 \mathrm{~mL}$ of dry THF cooled at $0{ }^{\circ} \mathrm{C}$. After $1 \mathrm{~h}$ of stirring at this temperature, 2.4 equiv of ethyl bromobutyrate was added. The reaction mixture was stirred further for $3 \mathrm{~h}$. Then, it was diluted with ethyl acetate $(15 \mathrm{~mL})$. The organic layer was washed with water $(4 \times 15 \mathrm{~mL})$ and brine $(15 \mathrm{~mL})$ and dried over anhydrous sodium sulfate. After filtration and removal of the solvent under reduced pressure, the crude residue was purified by silica gel column chromatography eluted with cyclohexane/EtOAc, leading to 67 with $70 \%$ yield. $R_{f}=0.35$ (petroleum ether $/ \mathrm{DCM} 7: 3$ ). ${ }^{1} \mathrm{H}$ NMR $\left(500 \mathrm{MHz}\right.$, acetone- $\left.d_{6}\right) \delta_{\mathrm{H}} 7.02(\mathrm{~d}, J=1.8 \mathrm{~Hz}, 1 \mathrm{H}), 6.97(\mathrm{~d}$, $J=8.2 \mathrm{~Hz}, 1 \mathrm{H}), 6.89(\mathrm{~d}, J=8.2 \mathrm{~Hz}, 1 \mathrm{H}), 6.56(\mathrm{~d}, J=3.2 \mathrm{~Hz}, 1 \mathrm{H})$, $6.46(\mathrm{~d}, J=3.2 \mathrm{~Hz}, 1 \mathrm{H}), 5.58(\mathrm{~s}, 1 \mathrm{H}), 5.37(\mathrm{t}, J=7.2 \mathrm{~Hz}, 1 \mathrm{H}), 5.17$ $(\mathrm{t}, J=7.2 \mathrm{~Hz}, 1 \mathrm{H}), 5.15(\mathrm{t}, J=7.2 \mathrm{~Hz}, 1 \mathrm{H}), 4.79(\mathrm{~d}, J=13.0 \mathrm{~Hz}, 1 \mathrm{H})$, $4.58(\mathrm{~s}, 2 \mathrm{H}), 4.49(\mathrm{~d}, J=13.0 \mathrm{~Hz}, 1 \mathrm{H}), 4.34(\mathrm{~d}, J=13.0 \mathrm{~Hz}, 1 \mathrm{H})$, $4.30(\mathrm{dd}, J=1.6 \mathrm{~Hz}, 13.0 \mathrm{~Hz}, 1 \mathrm{H}), 4.09(\mathrm{t}, J=7.2 \mathrm{~Hz}, 3 \mathrm{H}), 3.91(\mathrm{t}, J$ $=6.2 \mathrm{~Hz}, 2 \mathrm{H}), 3.79(\mathrm{~s}, 6 \mathrm{H}), 2.72(\mathrm{t}, J=6.8 \mathrm{~Hz}, 2 \mathrm{H}), 2.46(\mathrm{t}, J=7.2$ $\mathrm{Hz}, 2 \mathrm{H}), 2.26-2.05(\mathrm{~m}, 11 \mathrm{H}), 2.03-1.96(\mathrm{~m}, 4 \mathrm{H}), 1.86-1.72(\mathrm{~m}$, $2 \mathrm{H}), 1.66-1.52(\mathrm{~m}, 2 \mathrm{H}), 1.60(\mathrm{~s}, 6 \mathrm{H}), 1.27(\mathrm{~s}, 3 \mathrm{H}), 1.24(\mathrm{t}, J=7.2$ $\mathrm{Hz}, 3 \mathrm{H}), 1.22(\mathrm{t}, J=7.2 \mathrm{~Hz}, 3 \mathrm{H}) .{ }^{13} \mathrm{C}$ NMR $\left(125 \mathrm{MHz}\right.$, acetone- $\left.d_{6}\right)$ $\delta_{\mathrm{C}} 173.4,152.5,150.5,149.9,146.7,136.4,134.8,132.7,131.0,127.3$, $125.8,125.6,125.4,121.7,119.6,116.2,112.6,111.9,110.8,102.2$, 75.9, 72.7, 67.7, 66.6, 60.6, 56.0 (2C), 40.3, 40.2, 40.0, 32.1, 31.2, $27.1,25.8,25.6,24.4,23.1,22.8,16.4,16.1,15.9,14.5$. HRMS (ESI) $m / z$ calcd for $\mathrm{C}_{40} \mathrm{H}_{58} \mathrm{NaO}_{8}[\mathrm{M}+\mathrm{Na}]^{+} 713.4024$, found 713.4023 .

2-(((2R)-2-((3E,7E)-11-(2-(3,4-Dimethoxyphenyl)-1,3-dioxan-5ylidene)-4,8-dimethylundeca-3,7-dien-1-yl)-2,8-dimethylchroman$6-y /)$ oxy)acetamide (69). 69 was obtained from 44 and bromoace- tamide with $66 \%$ yield after purification through column chromatography eluted with petroleum ether/DCM. $R_{f}=0.30$ (ethyl acetate/ cyclohexane 5:5). ${ }^{1} \mathrm{H}$ NMR $\left(500 \mathrm{MHz}\right.$, acetone- $\left.d_{6}\right) \delta_{\mathrm{H}} 7.08(\mathrm{bs}, 2 \mathrm{H})$, $7.01(\mathrm{~d}, J=1.6 \mathrm{~Hz}, 1 \mathrm{H}), 6.96(\mathrm{dd}, J=1.6 \mathrm{~Hz}, 8.3 \mathrm{~Hz}, 1 \mathrm{H}), 6.89(\mathrm{~d}, J$ $=8.3 \mathrm{~Hz}, 1 \mathrm{H}), 6.63(\mathrm{~d}, J=2.8 \mathrm{~Hz}, 1 \mathrm{H}), 6.53(\mathrm{~d}, J=2.8 \mathrm{~Hz}, 1 \mathrm{H}), 5.58$ $(\mathrm{s}, 1 \mathrm{H}), 5.37(\mathrm{t}, J=7.2 \mathrm{~Hz}, 1 \mathrm{H}), 5.17(\mathrm{t}, J=7.2 \mathrm{~Hz}, 1 \mathrm{H}), 5.14(\mathrm{t}, J=$ $7.2 \mathrm{~Hz}, 1 \mathrm{H}), 4.79(\mathrm{~d}, J=13.0 \mathrm{~Hz}, 1 \mathrm{H}), 4.48(\mathrm{~d}, J=13.0 \mathrm{~Hz}, 1 \mathrm{H})$, $4.34(\mathrm{~d}, J=13.0 \mathrm{~Hz}, 1 \mathrm{H}), 4.30(\mathrm{~d}, J=13.0 \mathrm{~Hz}, 1 \mathrm{H}), 4.31(\mathrm{~s}, 2 \mathrm{H})$, $3.79(\mathrm{~s}, 6 \mathrm{H}), 2.73(\mathrm{t}, J=6.8 \mathrm{~Hz}, 2 \mathrm{H}), 2.12(\mathrm{~s}, 3 \mathrm{H}), 2.24-1.96(\mathrm{~m}$, $10 \mathrm{H}), 1.88-1.69(\mathrm{~m}, 2 \mathrm{H}), 1.67-1.52(\mathrm{~m}, 2 \mathrm{H}), 1.60(\mathrm{~s}, 6 \mathrm{H}), 1.26(\mathrm{~s}$, $3 \mathrm{H}) .{ }^{13} \mathrm{C}$ NMR $\left(125 \mathrm{MHz}\right.$, acetone- $\left.d_{6}\right) \delta_{\mathrm{C}} 171.2,151.4,150.4,149.9$ (2C), 147.4, 135.4, 134.8, 132.7, 131.0, 127.6, 125.8, 125.6, 125.4, $121.9,119.6,116.4,113.4,111.9,110.8,102.2,76.1,72.7,68.5,66.6$, 56.0 (2C), 40.3, 40.2, 40.0, 32.2, 27.2, 25.8, 24.4, 23.1, 22.9, 16.4 16.1, 15.9. HRMS (ESI) $\mathrm{m} / z$ calcd for $\mathrm{C}_{38} \mathrm{H}_{51} \mathrm{NNaO}_{7}[\mathrm{M}+\mathrm{Na}]^{+}$ 656.3558 , found 656.3551 .

4-(((2R)-2-((3E,7E)-11-(2-(3,4-Dimethoxyphenyl)-1,3-dioxan-5ylidene)-4,8-dimethylundeca-3,7-dien-1-yl)-2,8-dimethylchroman6-yl)oxy)butanoic Acid (45). $\mathrm{LiOH}$ (93 $\mu \mathrm{L}$ of a $10 \%$ aqueous solution, 3 equiv) was added to a solution of $67(90 \mathrm{mg}, 0.13 \mathrm{mmol}, 1$ equiv) in THF $(3 \mathrm{~mL})$. The reaction mixture was stirred at room temperature for $3 \mathrm{~h}$. It was then diluted with water and acidified with $1 \mathrm{~N} \mathrm{HCl}$ down to $\mathrm{pH} 4-5$. The aqueous layer was extracted with $3 \times$ $10 \mathrm{~mL}$ of EtOAc. The combined organic extracts were washed with brine, dried over anhydrous sodium sulfate, filtered, and concentrated to dryness under reduced pressure. 45 was obtained with $85 \%$ yield. $R_{f}$ $=0.30$ (acetone/petroleum ether 4:6). ${ }^{1} \mathrm{H}$ NMR $(500 \mathrm{MHz}$, acetone$\left.d_{6}\right) \delta_{\mathrm{H}} 7.02(\mathrm{~d}, J=1.8 \mathrm{~Hz}, 1 \mathrm{H}), 6.97(\mathrm{~d}, J=8.2 \mathrm{~Hz}, 1 \mathrm{H}), 6.89(\mathrm{~d}, J=$ $8.2 \mathrm{~Hz}, 1 \mathrm{H}), 6.56(\mathrm{~d}, J=3.2 \mathrm{~Hz}, 1 \mathrm{H}), 6.46(\mathrm{~d}, J=3.2 \mathrm{~Hz}, 1 \mathrm{H}), 5.58$ $(\mathrm{s}, 1 \mathrm{H}), 5.37(\mathrm{t}, J=7.2 \mathrm{~Hz}, 1 \mathrm{H}), 5.17(\mathrm{t}, J=7.2 \mathrm{~Hz}, 1 \mathrm{H}), 5.15(\mathrm{t}, J=$ $7.2 \mathrm{~Hz}, 1 \mathrm{H}), 4.79(\mathrm{~d}, J=13.0 \mathrm{~Hz}, 1 \mathrm{H}), 4.58(\mathrm{~s}, 2 \mathrm{H}), 4.49(\mathrm{~d}, J=13.0$ $\mathrm{Hz}, 1 \mathrm{H}), 4.34(\mathrm{~d}, J=13.0 \mathrm{~Hz}, 1 \mathrm{H}), 4.30(\mathrm{dd}, J=13.0 \mathrm{~Hz}, 1.6 \mathrm{~Hz}$, $1 \mathrm{H}), 4.09(\mathrm{q}, J=7.2 \mathrm{~Hz}, 2 \mathrm{H}), 3.92(\mathrm{t}, J=6.2 \mathrm{~Hz}, 2 \mathrm{H}), 3.79(\mathrm{~s}, 6 \mathrm{H})$, $2.72(\mathrm{t}, J=6.8 \mathrm{~Hz}, 2 \mathrm{H}), 2.48(\mathrm{t}, J=7.2 \mathrm{~Hz}, 2 \mathrm{H}), 2.26-2.05(\mathrm{~m}, 8 \mathrm{H})$, $2.11(\mathrm{~s}, 3 \mathrm{H}), 2.03-1.96(\mathrm{~m}, 4 \mathrm{H}), 1.84-1.66(\mathrm{~m}, 2 \mathrm{H}), 1.66-1.52(\mathrm{~m}$, $2 \mathrm{H}), 1.60(\mathrm{~s}, 6 \mathrm{H}), 1.27(\mathrm{~s}, 3 \mathrm{H}) .{ }^{13} \mathrm{C}$ NMR $\left(125 \mathrm{MHz}\right.$, acetone- $\left.d_{6}\right) \delta_{\mathrm{C}}$ $174.4,152.5,150.4,149.8,146.7,135.4,134.8,132.7,131.0,127.3$, $125.7,125.6,125.4,121.7,119.6,116.2,112.7,111.8,110.7,102.2$, $75.9,72.7,67.7,66.5,56.0,55.9,40.3,40.2,40.0,32.1,30.8,27.5$, $27.1,25.8,25.6,24.4,23.1,22.8,16.4,16.1,15.9$. HRMS (ESI) $\mathrm{m} / z$ calcd for $\mathrm{C}_{40} \mathrm{H}_{54} \mathrm{NaO}_{8}[\mathrm{M}+\mathrm{Na}]^{+} 685.3711$, found 685.3710

(2R)-2-((3E,7E)-4,8-Dimethyl-11-(2-(4-nitrophenyl)-1,3-dioxan-5ylidene) undeca-3,7-dien-1-yl)-2,8-dimethylchroman-6-ol (70). To a stirred solution of $27 \mathrm{~d}(216 \mathrm{mg}, 0.5 \mathrm{mmol})$ in dry THF $(5 \mathrm{~mL})$ were added pTSA (22 mg, $0.12 \mathrm{mmol}, 0.23$ equiv) and a solution of 4 nitrobenzaldehyde dimethyl acetal (198 mg, $1 \mathrm{mmol}, 2$ equiv) in dry THF $(5 \mathrm{~mL})$. The reaction mixture was refluxed for $5 \mathrm{~h}$. The reaction mixture was cooled down to room temperature, and EtOAc $(30 \mathrm{~mL})$ was added. The organic layer was washed with a saturated aqueous solution of $\mathrm{NaHCO}_{3}(20 \mathrm{~mL})$ and brine $(20 \mathrm{~mL})$, dried over $\mathrm{Na}_{2} \mathrm{SO}_{4}$, and evaporated to dryness. Purification by column chromatography on silica gel and eluting with a petroleum ether/acetone (PE/ acetone) mixture afforded the desired protected product 70 with $78 \%$ yield. $R_{f}=0.3$ (petroleum ether/acetone 85:15). ${ }^{1} \mathrm{H}$ NMR $(500 \mathrm{MHz}$, acetone- $\left.d_{6}\right) \delta_{\mathrm{H}} 8.24(\mathrm{~d}, J=8.9 \mathrm{~Hz}, 2 \mathrm{H}), 7.73(\mathrm{~d}, J=8.9 \mathrm{~Hz}, 2 \mathrm{H}), 7.44$ $(\mathrm{s}, 1 \mathrm{H}), 6.46(\mathrm{~d}, J=2.8 \mathrm{~Hz}, 1 \mathrm{H}), 6.36(\mathrm{~d}, J=2.8 \mathrm{~Hz}, 1 \mathrm{H}), 5.82(\mathrm{~s}$, $1 \mathrm{H}), 5.43(\mathrm{t}, J=7.2 \mathrm{~Hz}, 1 \mathrm{H}), 5.17(\mathrm{t}, J=7.2 \mathrm{~Hz}, 1 \mathrm{H}), 5.14(\mathrm{t}, J=7.2$ $\mathrm{Hz}, 1 \mathrm{H}), 4.87(\mathrm{~d}, J=13.0 \mathrm{~Hz}, 1 \mathrm{H}), 4.58(\mathrm{~d}, J=13.0 \mathrm{~Hz}, 1 \mathrm{H}), 4.44$. $(\mathrm{d}, J=13.0 \mathrm{~Hz}, 1 \mathrm{H}), 4.38(\mathrm{~d}, J=13.0 \mathrm{~Hz}, 1 \mathrm{H}), 2.67(\mathrm{t}, J=6.8 \mathrm{~Hz}$, $2 \mathrm{H}), 2.09(\mathrm{~s}, 3 \mathrm{H}), 2.24-2.07(\mathrm{~m}, 6 \mathrm{H}), 2.03-1.96(\mathrm{~m}, 4 \mathrm{H}), 1.88-$ $1.69(\mathrm{~m}, 2 \mathrm{H}), 1.67-1.52(\mathrm{~m}, 2 \mathrm{H}), 1.60(\mathrm{~s}, 6 \mathrm{H}), 1.27(\mathrm{~s}, 3 \mathrm{H}) .{ }^{13} \mathrm{C}$ NMR $\left(125 \mathrm{MHz}\right.$, acetone- $\left.d_{6}\right) \delta_{\mathrm{C}} 150.4,148.8,146.3,145.6,135.2$, $134.6,130.2,128.2$ (2C), 127.1, 126.4, 125.6, 125.2, 123.9 (2C), $121.6,116.3,113.3,100.3,75.7,72.7,66.6,40.2,40.1,39.8,32.0,27.0$, 25.7, 24.2, 22.9, 22.7, 16.1, 15.9, 15.7. HRMS (FAB) $\mathrm{m} / z$ calcd for $\mathrm{C}_{34} \mathrm{H}_{43} \mathrm{NNaO}_{6}[\mathrm{M}+\mathrm{Na}]^{+}$584.2983, found 584.2974

(2R)-2-((3E,7E)-4,8-Dimethyl-11-(2-(4-nitrophenyl)-1,3-dioxan-5ylidene) undeca-3,7-dien-1-yl)-5-(hydroxymethyl)-2,8-dimethylchroman-6-ol (48). In a two-neck round-bottom flask under a nitrogen atmosphere, acetic acid ( $4 \mu \mathrm{L}, 0.05 \mathrm{mmol}, 0.6$ equiv), boric 
acid ( $17 \mathrm{mg}, 0.27 \mathrm{mmol}, 3$ equiv), and paraformaldehyde $(48 \mathrm{mg}$, $2.62 \mathrm{mmol}, 36$ equiv) were added to a solution of the acetal 70 (50 $\mathrm{mg}, 0.09 \mathrm{mmol}, 1$ equiv) in $5 \mathrm{~mL}$ of dry toluene. The reaction mixture was refluxed for $12 \mathrm{~h}$. After cooling at room temperature, it was diluted with toluene $(20 \mathrm{~mL})$. The organic layer was washed with water $(20 \mathrm{~mL})$ and then stirred for $30 \mathrm{~min}$ with a $5 \%$ aqueous solution of sodium carbonate. The organic layer was washed further with water $(15 \mathrm{~mL})$ and brine $(15 \mathrm{~mL})$, dried over anhydrous sodium sulfate, and filtered. After removal of the solvent under reduced pressure, the crude product was purified using preparative TLC eluted with a mixture of petroleum ether/acetone/dichloromethane (8:2:1), leading to 48 with $55 \%$ yield $(33 \mathrm{mg}) . R_{f}=0.30$ (petroleum ether/ acetone 8:2). ${ }^{1} \mathrm{H}$ NMR $\left(400 \mathrm{MHz}\right.$, acetone- $\left.d_{6}\right) \delta_{\mathrm{H}} 8.25(\mathrm{~d}, J=8.8 \mathrm{~Hz}$, $2 \mathrm{H}), 8.02(\mathrm{~s}, 1 \mathrm{H}), 7.73(\mathrm{~d}, J=8.8 \mathrm{~Hz}, 2 \mathrm{H}), 6.48(\mathrm{~s}, 1 \mathrm{H}), 5.82(\mathrm{~s}$, $1 \mathrm{H}), 5.43(\mathrm{t}, J=7.2 \mathrm{~Hz}, 1 \mathrm{H}), 5.17-5.14(\mathrm{~m}, 2 \mathrm{H}), 4.87(\mathrm{~d}, J=13.0$ $\mathrm{Hz}, 1 \mathrm{H}), 4.74(\mathrm{~d}, J=4.5 \mathrm{~Hz}, 2 \mathrm{H}), 4.57(\mathrm{~d}, J=13.0 \mathrm{~Hz}, 1 \mathrm{H}), 4.44$. (d, $J=13.0 \mathrm{~Hz}, 1 \mathrm{H}), 4.38(\mathrm{~d}, J=13.0 \mathrm{~Hz}, 1 \mathrm{H}), 4.26-4.23(\mathrm{~m}, 1 \mathrm{H}), 2.73$ $(\mathrm{t}, J=6.8 \mathrm{~Hz}, 2 \mathrm{H}), 2.11(\mathrm{~s}, 3 \mathrm{H}), 2.26-2.09(\mathrm{~m}, 9 \mathrm{H}), 2.03-1.96(\mathrm{~m}$, $4 \mathrm{H}), 1.88-1.73(\mathrm{~m}, 2 \mathrm{H}), 1.67-1.52(\mathrm{~m}, 2 \mathrm{H}), 1.61(\mathrm{~s}, 3 \mathrm{H}) 1.60(\mathrm{~s}$, $3 \mathrm{H}), 1.24(\mathrm{~s}, 3 \mathrm{H}) .{ }^{13} \mathrm{C}$ NMR $\left(100 \mathrm{MHz}\right.$, acetone- $\left.d_{6}\right) \delta_{\mathrm{C}} 149.5,149.0$, 146.5, 145.6, 135.4, 134.8, 130.4, 128.4 (2C), 126.6, 126.4, 125.7, $125.5,124.0$ (2C), 120.2, 116.8, 100.5, 74.9, 72.9, 66.8, 58.4, 40.3 (2C), 40.0, 39.9, 32.1, 27.2, 25.8, 24.1, 22.9, 20.2, 16.3, 16.0, 15.9. HRMS (FAB) $m / z$ calcd for $\mathrm{C}_{35} \mathrm{H}_{45} \mathrm{NO}_{7}[\mathrm{M}]^{+} 591.3190$, found 591.3177.

(2R)-2-((3E, 7E)-11-(2-(3,4-Dimethoxyphenyl)-1,3-dioxan-5-ylidene)-4,8-dimethylundeca-3,7-dien-1-yl)-7-(hydroxymethyl)-2,5,8trimethylchroman-6-ol (46). To a stirred solution of $64(152 \mathrm{mg}$, $0.25 \mathrm{mmol})$ in dry THF $(20 \mathrm{~mL})$ were added magnesium chloride (238 mg, 10 equiv), paraformaldehyde ( $249 \mathrm{mg}, 32$ equiv), and triethylamine ( $1.18 \mathrm{~mL}, 32$ equiv) at room temperature. The mixture was stirred under reflux for $2 \mathrm{~h}$. The heterogeneous mixture was cooled down to room temperature, and $1 \mathrm{~N} \mathrm{HCl}(10 \mathrm{~mL})$ and $\mathrm{Et}_{2} \mathrm{O}$ $(30 \mathrm{~mL})$ were added dropwise. The organic layer was separated, and the aqueous layer was extracted with $\mathrm{Et}_{2} \mathrm{O}(2 \times 10 \mathrm{~mL})$. The combined organic extracts were washed with brine $(20 \mathrm{~mL})$, dried over $\mathrm{Na}_{2} \mathrm{SO}_{4}$, and evaporated to dryness. Purification by column chromatography on silica gel, using a petroleum ether/acetone/DCM (7:2:1) mixture as the mobile phase, afforded 46 (33\% yield) along with the desired formylated product 47 with $36 \%$ yield. $R_{f}=0.68$ (petroleum ether/acetone/DCM 7:2:1). Pale-yellow oil; ${ }^{1} \mathrm{H}$ NMR $\left(500 \mathrm{MHz}\right.$, acetone- $\left.d_{6}\right) \delta_{\mathrm{H}} 8.25(\mathrm{~s}, 1 \mathrm{H}, \mathrm{OH}), 7.02(\mathrm{~d}, J=1.8 \mathrm{~Hz}$, $1 \mathrm{H}), 6.98(\mathrm{dd}, J=1.8 \mathrm{~Hz}, 8.2 \mathrm{~Hz}, 1 \mathrm{H}), 6.89(\mathrm{~d}, J=8.2 \mathrm{~Hz}, 1 \mathrm{H}), 5.58$ $(\mathrm{s}, 1 \mathrm{H}), 5.36(\mathrm{t}, J=7.2 \mathrm{~Hz}, 1 \mathrm{H}), 5.16(\mathrm{t}, J=7.2 \mathrm{~Hz}, 1 \mathrm{H}), 5.14(\mathrm{t}, J=$ $7.2 \mathrm{~Hz}, 1 \mathrm{H}), 4.92(\mathrm{t}, J=4.5 \mathrm{~Hz}, 1 \mathrm{H}), 4.85(\mathrm{~d}, J=5.0 \mathrm{~Hz}, 2 \mathrm{H}), 4.79$ $(\mathrm{d}, J=13.0 \mathrm{~Hz}, 1 \mathrm{H}), 4.48(\mathrm{~d}, J=13.0 \mathrm{~Hz}, 1 \mathrm{H}), 4.33(\mathrm{~d}, J=13.0 \mathrm{~Hz}$, $1 \mathrm{H}), 4.31(\mathrm{~d}, J=13.0 \mathrm{~Hz}, 1 \mathrm{H}), 3.79(\mathrm{~s}, 3 \mathrm{H}), 3.78(\mathrm{~s}, 3 \mathrm{H}), 2.60(\mathrm{t}, J=$ $6.8 \mathrm{~Hz}, 2 \mathrm{H}), 2.05(\mathrm{~s}, 6 \mathrm{H}), 2.24-2.06(\mathrm{~m}, 6 \mathrm{H}), 2.04-1.97(\mathrm{~m}, 6 \mathrm{H}, \mathrm{H}-$ 17), $1.86-1.71(\mathrm{~m}, 2 \mathrm{H}), 1.66-1.48(\mathrm{~m}, 2 \mathrm{H}), 1,60(\mathrm{~s}, 6 \mathrm{H}), 1.23(\mathrm{~s}$, $3 \mathrm{H}) .{ }^{13} \mathrm{C}$ NMR $\left(125 \mathrm{MHz}\right.$, acetone- $\left.d_{6}\right) \delta_{\mathrm{C}} 150.5,149.9(2 \mathrm{C}), 148.5$, 145.2 , 135.5, 134.8, 132.7, 131.0, 125.8, 125.6, 125.5, 122.9, 120.8, $120.8,120.1,119.6,111.9,110.8,102.2,74.8,72.7,66.6,60.9,56.0$ (2C), 40.3, 40.0 (2C), 32.3, 27.1, 25.8, 24.1, 22.9, 21.3, 16.0, 15.9, 11.0, 10.9. HRMS (FAB) $\mathrm{m} / z$ calcd for $\mathrm{C}_{38} \mathrm{H}_{52} \mathrm{O}_{7}\left[\mathrm{M}^{+\bullet}\right]$ 620.3713, found 620.3711 .

4-(((2R)-2-((3E,7E)-11-(2-(3,4-Dimethoxyphenyl)-1,3-dioxan-5ylidene)-4,8-dimethylundeca-3,7-dien-1-yl)-2,8-dimethylchroman6-yl)oxy)-4-oxobutanoic Acid (68). Under a nitrogen atmosphere, succinic anhydride (175 mg, $1.79 \mathrm{mmol}, 10.3$ equiv) and triethylamine (244 $\mu \mathrm{L}, 1.79 \mathrm{mmol}, 10.3$ equiv) were added to a dry THF solution $(4 \mathrm{~mL})$ of acetal $64(100 \mathrm{mg}, 174 \mathrm{mmol}, 1.0$ equiv). The reaction mixture was stirred at room temperature for $20 \mathrm{~h}$. It was then diluted with water and acidified to $\mathrm{pH} 4$ with $1 \mathrm{~N} \mathrm{HCl}$. The aqueous layer was extracted three times with ethyl acetate $(3 \times 15 \mathrm{~mL})$. The combined organic layers were washed once with water and brine, dried over sodium sulfate, filtered, and concentrated under reduced pressure to yield $135 \mathrm{mg}$ of $\mathbf{6 8}$ as an oil. The product was used without further purification. $R_{f}=0.30$ (petroleum ether/acetone 3:7). ${ }^{1} \mathrm{H}$ NMR $\left(400 \mathrm{MHz}\right.$, acetone- $\left.d_{6}\right) \delta_{\mathrm{H}} 7.02(\mathrm{~d}, J=1.8 \mathrm{~Hz}, 1 \mathrm{H}), 6.97(\mathrm{~d}$, $J=8.2 \mathrm{~Hz}, 1 \mathrm{H}), 6.89(\mathrm{~d}, J=8.2 \mathrm{~Hz}, 1 \mathrm{H}), 6.68(\mathrm{~d}, J=3.2 \mathrm{~Hz}, 1 \mathrm{H})$, $6.63(\mathrm{~d}, J=3.2 \mathrm{~Hz}, 1 \mathrm{H}), 5.58(\mathrm{~s}, 1 \mathrm{H}), 5.37(\mathrm{t}, J=7.2 \mathrm{~Hz}, 1 \mathrm{H}), 5.18$ $(\mathrm{t}, J=7.2 \mathrm{~Hz}, 1 \mathrm{H}), 5.15(\mathrm{t}, J=7.2 \mathrm{~Hz}, 1 \mathrm{H}), 4.79(\mathrm{~d}, J=13.0 \mathrm{~Hz}, 1 \mathrm{H})$, $4.49(\mathrm{~d}, J=13.0 \mathrm{~Hz}, 1 \mathrm{H}), 4.34(\mathrm{~d}, J=13.0 \mathrm{~Hz}, 1 \mathrm{H}), 4.30(\mathrm{dd}, J=$ $13.0 \mathrm{~Hz}, 1.6 \mathrm{~Hz}, 1 \mathrm{H}), 3.79(\mathrm{~s}, 6 \mathrm{H}), 2.80(\mathrm{t}, J=7.2 \mathrm{~Hz}, 2 \mathrm{H}), 2.75(\mathrm{t}, J$ $=7.2 \mathrm{~Hz}, 2 \mathrm{H}), 2.70(\mathrm{t}, J=6.2 \mathrm{~Hz}, 2 \mathrm{H}), 2.25-2.08(\mathrm{~m}, 6 \mathrm{H}), 2.13(\mathrm{~s}$, $3 \mathrm{H}), 2.03-1.96(\mathrm{~m}, 4 \mathrm{H}), 1.90-1.72(\mathrm{~m}, 2 \mathrm{H}), 1.68-1.52(\mathrm{~m}, 2 \mathrm{H})$, $1.61(\mathrm{~s}, 6 \mathrm{H}), 1.29(\mathrm{~s}, 3 \mathrm{H}) .{ }^{13} \mathrm{C}$ NMR $\left(100 \mathrm{MHz}\right.$, acetone- $\left.d_{6}\right) \delta_{\mathrm{C}}$ $173.8,172.1,150.4,149.8$ (2C), 150.2, 143.9, 135.4, 134.8, 132.7, $131.0,127.3,125.8,125.6,125.4,122.1,121.1,120.2$, 119.6, 111.8, $110.7,102.2,76.6,72.7,66.6,56.0$ (2C), 40.3 (2C), 40.0, 31.7, 29.5, $29.2,27.1,25.6,24.4,24.3,22.8,16.2,16.1,15.9$. HRMS (FAB) $\mathrm{m} / \mathrm{z}$ calcd for $\mathrm{C}_{40} \mathrm{H}_{53} \mathrm{O}_{9}[\mathrm{M}+\mathrm{H}]^{+} 677.3684$, found 677.3674 .

4-(((R)-2-((3E,7E)-13-Hydroxy-12-(hydroxymethyl)-4,8-dimethyltrideca-3,7,11-trien-1-yl)-2,8-dimethylchroman-6-yl)oxy)-4-oxobutanoic Acid (31). para-Toluenesulfonic acid (1.15 equiv) was added to a solution of acetal 68 ( 1 equiv) in THF $(0.05 \mathrm{M})$. The reaction mixture was stirred at room temperature for $1 \mathrm{~h}$ and was diluted with EtOAc. The organic layer was washed twice with a saturated aqueous solution of $\mathrm{NaHCO}_{3}$, twice with water, and once with brine. It was then dried over anhydrous sodium sulfate, filtered, and concentrated under reduced pressure. The crude residue was purified by $\mathrm{C} 18$ flash chromatography using a water $/ \mathrm{MeOH}$ gradient leading to 31 with $60 \%$ yield. ${ }^{1} \mathrm{H}$ NMR $\left(400 \mathrm{MHz}\right.$, acetone- $\left.d_{6}\right) \delta_{\mathrm{H}} 6.68(\mathrm{~d}, J=3.2 \mathrm{~Hz}$, $1 \mathrm{H}), 6.63(\mathrm{~d}, J=3.2 \mathrm{~Hz}, 1 \mathrm{H}), 5.47(\mathrm{t}, J=7.2 \mathrm{~Hz}, 1 \mathrm{H}), 5.18-5.14(\mathrm{~m}$, $2 \mathrm{H}), 4.17(\mathrm{~s}, 2 \mathrm{H}), 4.09(\mathrm{~s}, 2 \mathrm{H}), 2.85-2.72(\mathrm{~m}, 4 \mathrm{H}), 2.71-2.68(\mathrm{~m}$, $2 \mathrm{H}), 2.21-2.08(\mathrm{~m}, 6 \mathrm{H}), 2.13(\mathrm{~s}, 3 \mathrm{H}), 2.03-1.96(\mathrm{~m}, 4 \mathrm{H}), 1.90-$ $1.75(\mathrm{~m}, 2 \mathrm{H}), 1.68-1.52(\mathrm{~m}, 2 \mathrm{H}), 1.61(\mathrm{~s}, 3 \mathrm{H}), 1.59(\mathrm{~s}, 3 \mathrm{H}), 1.29(\mathrm{~s}$, $3 \mathrm{H}) .{ }^{13} \mathrm{C}$ NMR $\left(100 \mathrm{MHz}\right.$, acetone- $\left.d_{6}\right) \delta_{\mathrm{C}} 173.6,172.0,150.2,143.9$, $140.1,135.6,135.3,127.7,127.3,125.2,122.1,121.8,120.2,76.6$, 65.9, 58.9, 40.5, 40.4, 40.3 (2C), 31.7, 29.7, 29.2, 27.2, 26.6, 24.4, 22.8 (2C), 16.2, 16.1, 15.9. IR (ATR) $\nu_{\max } 3425,2972,2901,1696,1406$, $1380,1225,1057,835 \mathrm{~cm}^{-1}$. HRMS (FAB) $\mathrm{m} / z$ calcd for $\mathrm{C}_{31} \mathrm{H}_{43} \mathrm{O}_{7}$ $[\mathrm{M}-\mathrm{H}]^{-}$527.3003, found 527.3008.

2-(((R)-2-((3E,7E)-13-Hydroxy-12-(hydroxymethyl)-4,8-dimethyltrideca-3,7,11-trien-1-yl)-2,8-dimethylchroman-6-yl)oxy)acetamide (32). 32 was obtained from 69 with $72 \%$ yield using the method described above for $\mathbf{3 1}$ after purification by preparative TLC using a mixture of DCM/EtOAc/MeOH (70:30:7) as the mobile phase. $R_{f}=$ 0.30 (cyclohexane/ethyl acetate 6:4). ${ }^{1} \mathrm{H}$ NMR $(500 \mathrm{MHz}$, acetone$\left.d_{6}\right) \delta_{\mathrm{H}} 7.08(\mathrm{bs}, 1 \mathrm{H}), 6.68(\mathrm{bs}, 1 \mathrm{H}), 6.63(\mathrm{~d}, J=2.8 \mathrm{~Hz}, 1 \mathrm{H}), 6.53(\mathrm{~d}$, $J=2.8 \mathrm{~Hz}, 1 \mathrm{H}), 5.46(\mathrm{t}, J=7.2 \mathrm{~Hz}, 1 \mathrm{H}), 5.18(\mathrm{t}, J=7.2 \mathrm{~Hz}, 1 \mathrm{H})$, $5.14(\mathrm{t}, J=7.2 \mathrm{~Hz}, 1 \mathrm{H}), 4.31(\mathrm{~s}, 2 \mathrm{H}), 4.17(\mathrm{~d}, J=5.5 \mathrm{~Hz}, 2 \mathrm{H}), 4.10$ $(\mathrm{d}, J=5.5 \mathrm{~Hz}, 2 \mathrm{H}), 3.65(\mathrm{t}, J=5.2 \mathrm{~Hz}, 1 \mathrm{H}), 3.57(\mathrm{t}, J=5.2 \mathrm{~Hz}, 1 \mathrm{H})$, $2.74(\mathrm{t}, J=6.8 \mathrm{~Hz}, 2 \mathrm{H}), 2.23-2.12(\mathrm{~m}, 4 \mathrm{H}), 2.12(\mathrm{~s}, 3 \mathrm{H}), 2.11-2.06$ $(\mathrm{m}, 2 \mathrm{H}), 2.01-1.96(\mathrm{~m}, 4 \mathrm{H}), 1.90-1.70(\mathrm{~m}, 2 \mathrm{H}), 1.65-1.55(\mathrm{~m}$, $2 \mathrm{H}), 1.58(\mathrm{~s}, 3 \mathrm{H}), 1.61(\mathrm{~s}, 3 \mathrm{H}), 1.31(\mathrm{~s}, 3 \mathrm{H}) .{ }^{13} \mathrm{C}$ NMR $(125 \mathrm{MHz}$, acetone- $\left.d_{6}\right) \delta_{\mathrm{C}} 171.2,151.5,147.4,140.2,135.6,135.3,127.6,127.5$, $125.3,125.2,121.9,116.4,113.0,76.1,68.5,65.9,58.8,40.5,40.4$, 40.1, 32.1, 27.2, 26.6, 24.4, 23.1, 22.8, 16.4, 16.1, 15.9. HRMS (ESI) $m / z$ calcd for $\mathrm{C}_{29} \mathrm{H}_{43} \mathrm{NNaO}_{5}[\mathrm{M}+\mathrm{Na}]^{+} 508.3034$, found 508.3032 .

Analysis of Pan Assay Interference Compounds (PAINS). All investigated compounds were examined for known classes of assay interference compounds using the bulk pattern checker of ZINC15 (http://zinc15.docking.org/patterns/home/). Compounds 23, 24, and 35-40 were detected as Mannich bases. They effectively inhibited 5-LOX in a cell-free assay, with a few exceptions $(\mathbf{2 4}, \mathbf{4 0})$, but were considerably less active in suppressing 5-LOX product formation in PMNL and therefore were not further investigated.

5-LOX Activity. Human recombinant 5-LOX was expressed in $E$. coli Bl21 (DE3) cells that were transformed with pT3-5LOX (wt 5LOX), 5-LOX_3W (triple mutation of Trp102Ala/Trp13Ala/ Trp75Ala), or 5-LOX_R (single mutant of the Arg101Asp plasmid) and purified on an ATP-agarose column (Econo-Pac, Bio-Rad, Hercules, CA) by affinity chromatography. ${ }^{6,75}$ In a first step, E. coli was lysed in $50 \mathrm{mM}$ triethanolamine $/ \mathrm{HCl} \mathrm{pH} 8.0$ with EDTA (5 $\mathrm{mM})$, soybean trypsin inhibitor $(60 \mu \mathrm{g} / \mathrm{mL})$, phenylmethylsulfonyl fluoride $(1 \mathrm{mM})$, dithiothreitol $(1 \mathrm{mM})$, and lysozyme $(1 \mathrm{mg} / \mathrm{mL})$ and sonified three times for $15 \mathrm{~s}$. The homogenate was centrifuged at $10000 \mathrm{~g}$ for $15 \mathrm{~min}$, followed by centrifugation of the supernatant at $40000 \mathrm{~g}$ for $70 \mathrm{~min}$ at $4{ }^{\circ} \mathrm{C}$. The supernatant was transferred to an 
ATP-agarose column (Sigma-Aldrich, Deisenhofen, Germany), which was sequentially washed with PBS pH 7.4, $1 \mathrm{mM}$ EDTA, $50 \mathrm{mM}$ phosphate buffer pH 7.4, $0.5 \mathrm{M} \mathrm{NaCl}, 1 \mathrm{mM}$ EDTA, and finally 50 $\mathrm{mM}$ phosphate buffer $\mathrm{pH} 7.4$ plus $1 \mathrm{mM}$ EDTA. The enzyme was eluted with $50 \mathrm{mM}$ phosphate buffer $\mathrm{pH} 7.4,50 \mathrm{mM}$ EDTA, and 20 mM ATP.

Purified 5-LOX $(0.5 \mu \mathrm{g}$ in PBS pH 7.4 containing $1 \mathrm{mM}$ EDTA and $1 \mathrm{mM} \mathrm{ATP}$ ) was preincubated with the vehicle (DMSO) or test compounds for $10 \mathrm{~min}$ and prewarmed at $37{ }^{\circ} \mathrm{C}$. 5-LOX product formation was started by addition of arachidonic acid (Sigma-Aldrich; $20 \mu \mathrm{M}$ or as indicated) and $\mathrm{CaCl}_{2}(2 \mathrm{mM})$ and stopped by an equal volume of ice-cold methanol after $10 \mathrm{~min}$ at $37^{\circ} \mathrm{C}$. Major 5-LOX metabolites (all-trans isomers of $\mathrm{LTB}_{4}$ and 5-HETE) were extracted on Sep-Pak C18 35 cc Vac Cartridges (Waters, Milford, MA), separated by RP-HPLC on a Nova-Pak C18 Radial-Pak column (4 $\mu \mathrm{m}, 5 \mathrm{~mm} \times 100 \mathrm{~mm}$, Waters) under isocratic conditions $(73 \%$ methanol $/ 27 \%$ water $/ 0.007 \%$ trifluoroacetic acid) at a flow rate of 1.2 $\mathrm{mL} / \mathrm{min}$, and detected at 235 and $280 \mathrm{~nm} .{ }^{75}$ Zileuton was used as the reference 5-LOX inhibitor. To investigate whether 27 a reversibly inhibits 5-LOX, the purified enzyme was preincubated with 27a at 0.3 $\mu \mathrm{M}$ for $15 \mathrm{~min}$. The reaction mix was then 10 -fold diluted to a final compound concentration of $0.03 \mu \mathrm{M}$, and arachidonic acid $(20 \mu \mathrm{M})$ and $\mathrm{CaCl}_{2}(1 \mathrm{mM})$ were added after another $5 \mathrm{~min}$ incubation on ice. To recognize nuisance inhibition, Triton X-100 (Sigma-Aldrich; $0.01 \%)$ was added to the reaction buffer.

Radical Scavenging Activity. Compound 27a was incubated with 2,2-diphenyl-1-picrylhydrazyl (DPPH, Sigma-Aldrich; $50 \mathrm{mM}$ ) in ethanol for $30 \mathrm{~min}$, and the absorbance was measured at $520 \mathrm{~nm}$ using a Multiskan Spectrum Microplate Reader (Thermo Fisher Scientific). ${ }^{72}$ The positive control ascorbic acid (Sigma-Aldrich; 25 $\mu \mathrm{M})$ scavenged DPPH radicals by $36 \pm 11 \%$.

Human Whole Blood and Blood Cells. Human PMNL, PBMC, monocytes, and platelets were freshly isolated from leukocyte concentrates that we obtained together with human whole blood (containing 3.13\% sodium citrate) from the Institute for Transfusion Medicine of the University Hospital Jena (Germany). ${ }^{76}$ Venous blood was collected in heparinized tubes (16 U heparin/mL blood), with informed consent of registered male and female healthy adult volunteers (18-65 years) who were fasted for at least $12 \mathrm{~h}$. These volunteers regularly donated blood (every 8-12 weeks) and were physically inspected by a clinician. They had not taken antibiotics or anti-inflammatory drugs for more than 10 days before blood donation and were free of apparent infections, inflammatory disorders, or acute allergic reactions.

Leukocytes were concentrated by centrifugation $(4000 \mathrm{~g} / 20 \mathrm{~min} /$ $20{ }^{\circ} \mathrm{C}$ ) of freshly withdrawn blood and subjected to density gradient centrifugation on a lymphocyte separation medium (LSM 1077, GE Healthcare, Freiburg, Germany). Erythrocytes were removed by dextran sedimentation and hypotonic lysis. PMNL were obtained from the cell pellet and platelets from the supernatant. The PBMC fraction was plated in cell culture flasks (Greiner, Nuertingen, Germany) for $1.5 \mathrm{~h}$ at $37{ }^{\circ} \mathrm{C}$ and $5 \% \mathrm{CO}_{2}$ in an RPMI 1640 medium (Sigma-Aldrich) with 5\% FCS (Sigma-Aldrich), $2 \mathrm{mM}$ L-glutamine (Sigma-Aldrich), and penicillin $(100 \mathrm{U} / \mathrm{mL}) /$ streptomycin $(100 \mu \mathrm{g} /$ $\mathrm{mL}$, GE Healthcare) (monocyte medium) to isolate adherent monocytes. The purity of monocytes ( $>85 \%)$ was determined from forward and side scatter properties, and CD14 surface expression was determined by flow cytometry (BD FACS Calibur, Heidelberg, Germany).

Monocytes were differentiated to macrophages by treatment with GM-CSF $(20 \mathrm{ng} / \mathrm{mL})$ for 6 days in an RPMI 1640 medium with $10 \%$ FCS, $2 \mathrm{mM}$ L-glutamine, and penicillin $(100 \mathrm{U} / \mathrm{mL}) /$ streptomycin $(100 \mu \mathrm{g} / \mathrm{mL})$. Macrophages were polarized to the M1 phenotype by stimulation with LPS (100 ng/mL, Sigma-Aldrich) and interferon (IFN) $-\gamma$ (20 ng/mL, Peprotech, Hamburg, Germany) for $48 \mathrm{~h}^{23}$

Experiments with blood and blood cells were approved by the ethics committee of the Friedrich-Schiller-University Jena.

5-LOX Product Formation by PMNL and Blood. Freshly isolated PMNL $\left(5 \times 10^{6}\right)$ suspended in PBS pH 7.4 with $1 \mathrm{mg} / \mathrm{mL}$ glucose or freshly withdrawn human whole blood were preincubated with the test compounds for $10 \mathrm{~min}$ (or as indicated) at $37^{\circ} \mathrm{C} .5$ LOX product formation in PMNL was triggered by addition of arachidonic acid $(20 \mu \mathrm{M})$ and/or $\mathrm{Ca}^{2+}$-ionophore A23187 $(2.5 \mu \mathrm{M}$; Sigma-Aldrich) followed by incubation for $10 \mathrm{~min}$ at $37^{\circ} \mathrm{C}$. The reaction was stopped with an equal volume of methanol.

Blood was treated with $\mathrm{Ca}^{2+}$-ionophore A23187 $(30 \mu \mathrm{M})$ for 10 min at $37{ }^{\circ} \mathrm{C}$ or was first primed for $30 \mathrm{~min}$ with LPS $(1 \mu \mathrm{g} / \mathrm{mL})$ and then stimulated with fMLP ( $1 \mu \mathrm{M}$; Sigma-Aldrich) for $15 \mathrm{~min}$. After the reaction was stopped on ice, plasma was prepared $(600 \mathrm{~g}, 10 \mathrm{~min}$, $4{ }^{\circ} \mathrm{C}$ ), and aliquots were mixed with an equal volume of methanol. Proteins were precipitated at $-20{ }^{\circ} \mathrm{C}$ for $2 \mathrm{~h}$ and removed by centrifugation $\left(600 \mathrm{~g}, 15 \mathrm{~min}, 4^{\circ} \mathrm{C}\right)$.

Major 5-LOX metabolites (all-trans isomers of $\mathrm{LTB}_{4}$ and 5-HETE) and, for PMNL, additionally 12-HETE (major 12-LOX product) and 15-HETE (major 15-LOX product) were extracted and analyzed by RP-HPLC as described for the determination of cell-free 5-LOX activity. Zileuton $(3 \mu \mathrm{M})$ was used as the reference 5-LOX inhibitor.

Fluorescence Spectroscopy of 5-LOX. Fluorescence spectroscopy measurements on human recombinant 5-LOX (Abcam, Cambridge, U.K.) were conducted in PBS pH 7.4 at $25{ }^{\circ} \mathrm{C}$ using an Edinburgh Instruments FLS920 Series fluorescence spectrophotometer (Livingston, U.K.). The effect of the ligand concentration was followed by means of tryptophan fluorescence, with excitation at 295 $\mathrm{nm}$ and emission collected between 310 and $450 \mathrm{~nm}$, using excitation and emission slits of 5 and $10 \mathrm{~nm}$, respectively. The concentration range of 5-LOX used through the experiments was $0.3-0.6 \mu \mathrm{M}$. 5LOX was titrated with a stock solution of the test compounds in dimethylformamide to yield an experimental compound concentration in the range of $0-10 \mu \mathrm{M}$. The final dimethylformamide concentration was kept under $5 \%$. After each addition, the sample was incubated for $10 \mathrm{~min}$ before measurement. The fluorescence emission intensity values were corrected for dilution and background noise. All conditions were measured independently and in duplicate.

The fluorescence emission spectral shift was used to monitor ligand-protein binding since significant variations of intensity were not observed. The fluorescence spectral shifts were analyzed by monitoring the alterations in the spectral center of mass by estimating the intensity-averaged emission wavelength $(\langle\lambda\rangle)$, as calculated from the following equation, where $F_{\mathrm{i}}$ is the fluorescence emission intensity at wavenumber $\nu_{\mathrm{i}}$, and the summation was performed over the range of measured $F$ values

$$
\frac{1}{\langle v\rangle}=\frac{\sum \frac{1}{\lambda_{\mathrm{i}}} F_{\mathrm{i}}}{\sum F_{\mathrm{i}}} \Leftrightarrow\langle\lambda\rangle=\frac{\sum F_{\mathrm{i}}}{\sum\left(\frac{F_{\mathrm{i}}}{\lambda_{\mathrm{i}}}\right)}
$$

Molecular Docking Simulations. The molecular docking simulation was conducted with GOLD 2020.2.0 (CCDC, Cambridge, U.K.). ${ }^{77}$ The built-in CHEMPLP scoring function was used to rescore the outputted poses (10 best-scored poses were kept for each compound). The stable crystallographic tridimensional structure of 5LOX was downloaded from the Protein Data Bank (PDB entry $3 \mathrm{O} 8 \mathrm{Y}){ }^{78}$ Four in silico mutations were inserted to return to the 5LOX wild-type sequence: E13W, H14F, G75W, and S76L. The residues were exchanged, and the structure was energetically minimized in Discovery Studio 3.5 (Biovia, San Diego, CA). ${ }^{79}$ Hydrogen atoms were added with GOLD, using default settings. The binding site was constituted by 11 amino acid residues: Gln15, Arg101, Tyr81, Tyr100, Arg101, Trp102, Val110, Glu134, Asp170, Arg401, and Glu 622. Hydrogen-bond constraints were applied to Trp102-He1, Val110-HN, Glu134-O $\varepsilon 1$, Asp170-O $\delta 1, \operatorname{Arg} 401-\mathrm{HH} 2$, and $\operatorname{Arg} 401-\mathrm{H} \varepsilon$ with the constraint weight varying from 7 to 40 and the minimum $\mathrm{H}$-bond geometry weight at 0.005 . The ligands were allowed to detect internal H-bonds, flip pyramidal $\mathrm{N}$, and flip amide bonds. Protein-ligand interactions of docking poses were analyzed using LigandScout 4.3 (Inteligand, Vienna, AT). ${ }^{80}$

Intracellular Concentrations of $12 \mathrm{a}$ and $27 \mathrm{a}$. PMNL $(1 \times$ $10^{7} / \mathrm{mL}$ ) were suspended in PBS pH 7.4 with $1 \mathrm{mg} / \mathrm{mL}$ glucose and incubated with a vehicle (DMSO, $0.1 \%), 27 \mathbf{a}$ or $12 \mathbf{a}(150 \mathrm{nM}$, each) for $20 \mathrm{~min}$ at $37^{\circ} \mathrm{C}$. Cells were centrifuged $\left(1200 \mathrm{~g}, 5 \mathrm{~min}, 4^{\circ} \mathrm{C}\right)$ and 
washed thrice with PBS pH 7.4 with $0.1 \%$ fatty-acid-free BSA (SigmaAldrich). Compounds were extracted and analyzed by UPLC-MS/MS as described below for LCMs and derivatives. The intracellular concentrations of $\mathbf{2 7 a}$ and $12 \mathrm{a}$ were calculated assuming a spherical cell shape with a diameter of $13 \mu \mathrm{m}$ (as measured using a Vi-CELL Series Cell Counter, Beckman Coulter, Krefeld, Germany) and an equal intracellular distribution. 13d (9 pmol) was used as the internal standard.

Monocyte and PBMC Viability. Monocytes $\left(4 \times 10^{5} / \mathrm{mL}\right)$ or PBMC $\left(2 \times 10^{6} / \mathrm{mL}\right)$ in a monocyte medium were treated with the vehicle $(0.1 \% \mathrm{DMSO})$ and test compounds for 2 or $24 \mathrm{~h}$ at $37^{\circ} \mathrm{C}$ and $5 \% \mathrm{CO}_{2}$. To measure mitochondrial dehydrogenase activity, 3-(4,5dimethylthiazol-2-yl)-2,5-diphenyltetrazolium bromide (MTT) (20 $\mu \mathrm{L}, 5 \mathrm{mg} / \mathrm{mL}$, Sigma-Aldrich) was added to PBMC. After $4 \mathrm{~h}$ in the darkness, the formed formazan product was solubilized (10\% SDS in $20 \mathrm{mM} \mathrm{HCl}$ ) and the absorbance was read at $570 \mathrm{~nm}$ using a Multiskan Spectrum microplate reader (Thermo Fisher Scientific) ${ }^{81}$ Staurosporine ( $3 \mu \mathrm{M}$; Merck Chemicals) was used as the cytotoxic reference compound.

$\mathrm{LDH}$ release was measured in monocytes using a CytoTox 96 nonradioactive cytotoxicity assay (Promega, Madison, WI) according to the manufacturer's instruction using Triton X-100 (0.8\%) as the maximum $\mathrm{LDH}$ release control.

Intracellular $\mathrm{Ca}^{2+}$ Influx. PMNL $\left(1 \times 10^{6}\right)$ were loaded with Fura-2/AM ( 2 nmol, Thermo Fisher Scientific) for $45 \mathrm{~min}$ at $37^{\circ} \mathrm{C}$. Washed cells in PBS pH 7.4 with $1 \mathrm{mg} / \mathrm{mL}$ glucose were preincubated with a vehicle (0.1\% DMSO) or 27 a for $10 \mathrm{~min}$ prior to addition of 1 $\mathrm{mM} \mathrm{Ca}{ }^{2+}$ and stimulation with $1 \mu \mathrm{M}$ fMLP for $10 \mathrm{~min}$. Intracellular $\mathrm{Ca}^{2+}$ concentrations were measured using a NOVOstar fluorescence microplate reader (BMG Labtech, Ortenberg, Germany) at $37{ }^{\circ} \mathrm{C}$. The emission wavelength was set to $510 \mathrm{~nm}$ and the excitation wavelengths to $340 \mathrm{~nm}\left(\mathrm{Ca}^{2+}\right.$-bound Fura-2) and $380 \mathrm{~nm}$ (free Fura$2){ }^{23}$ To define $100 \% \mathrm{Ca}^{2+}$ influx, the difference between the maximal influx (cell lysis by Triton X-100) and minimal influx (subsequent chelation of $\mathrm{Ca}^{2+}$ by EDTA) was measured for each experiment.

mPGES-1 Activity. Human lung carcinoma A549 cells (ATCC, Manassas, VA) were cultivated in DMEM (high glucose, $4.5 \mathrm{~g} / \mathrm{L}$; GE Healthcare) with $10 \%$ FCS and penicillin $(100 \mathrm{U} / \mathrm{mL}) /$ streptomycin $(100 \mu \mathrm{g} / \mathrm{mL})$ at $37^{\circ} \mathrm{C}$ and $5 \% \mathrm{CO}_{2}$. Confluent cells were detached by trypsin-EDTA (GE Healthcare) and reseeded at a density of $1 \times 10^{4}$ cells $/ \mathrm{cm}^{2}$.

A549 cells were treated with IL- $1 \beta(2 \mathrm{ng} / \mathrm{mL})$ at $37{ }^{\circ} \mathrm{C}$ and $5 \%$ $\mathrm{CO}_{2}$ for $48 \mathrm{~h}$ to induce mPGES-1 expression. ${ }^{81}$ Cell pellets of harvested cells were frozen in liquid nitrogen and then incubated on ice for $15 \mathrm{~min}$ and homogenized in ice-cold homogenization buffer (0.1 M potassium phosphate buffer $\mathrm{pH} 7.4,1 \mathrm{mM}$ phenylmethanesulfonyl fluoride (PMSF), $60 \mu \mathrm{g} / \mathrm{mL}$ soybean trypsin inhibitor (STI), $1 \mu \mathrm{g} / \mathrm{mL}$ leupeptin, $2.5 \mathrm{mM}$ glutathione, and 250 $\mathrm{mM}$ sucrose $)$ by sonication $\left(3 \times 20 \mathrm{~s}, 4{ }^{\circ} \mathrm{C}\right)$. Differential centrifugation at $10000 \mathrm{~g}$ for $10 \mathrm{~min}$ and $174000 \mathrm{~g}$ for $1 \mathrm{~h}$ at $4{ }^{\circ} \mathrm{C}$ yielded the microsomal fraction. The pellet was resuspended in homogenization buffer and diluted in $0.1 \mathrm{M}$ potassium phosphate buffer $\mathrm{pH} 7.4$ containing $2.5 \mathrm{mM}$ glutathione. Microsomal membranes (adjusted to $2.5-5 \mu \mathrm{g}$ total protein) were preincubated with 27 a for $15 \mathrm{~min}$ at $4{ }^{\circ} \mathrm{C}$. The mPGES-1 substrate $\mathrm{PGH}_{2}(20 \mu \mathrm{M})$ was added to induce $\mathrm{PGE}_{2}$ formation. The reaction was stopped after $1 \mathrm{~min}$ by addition of an equal volume of aqueous $40 \mathrm{mM} \mathrm{FeCl}_{2}, 80$ $\mathrm{mM}$ citric acid, and $1 \mathrm{nmol} 11 \beta-\mathrm{PGE}_{2}$ (Cayman Chemicals) as the internal standard. $\mathrm{PGE}_{2}$ was extracted on Sep-Pak C18 35 cc Vac Cartridges (Waters) and separated on a Nova-Pak C18 Radial-Pak Column $(4 \mu \mathrm{m}, 5 \mathrm{~mm} \times 100 \mathrm{~mm}$, Waters $)$ under isocratic conditions (30\% acetonitrile/70\% $\mathrm{H}_{2} \mathrm{O} / 0.007 \%$ trifluoroacetic acid) at a flow rate of $1 \mathrm{~mL} / \mathrm{min}$ and detection at $195 \mathrm{~nm} .{ }^{82}$ The mPGES- 1 inhibitor MK-886 $(10 \mu \mathrm{M})$ was used as the control.

COX-1 and COX-2 Activity. Purified ovine COX-1 (Cayman Chemicals; 50 units) or human recombinant COX-2 (Cayman Chemicals; 20 units) was dissolved in $100 \mathrm{mM}$ Tris buffer $\mathrm{pH} 8,5$ $\mathrm{mM}$ glutathione, $5 \mu \mathrm{M}$ hemoglobin, and $100 \mu \mathrm{M}$ EDTA. COX isoenzymes were preincubated with the vehicle (DMSO) or $\mathbf{2 7}$ a for 5 min at $4{ }^{\circ} \mathrm{C}$ and $1 \mathrm{~min}$ at $37^{\circ} \mathrm{C}$. Addition of arachidonic acid (COX-
1: $5 \mu \mathrm{M}$; COX-2: $2 \mu \mathrm{M})$ initiated the formation of COX-derived 12(S)-hydroxy-5-cis-8,10-trans-heptadecatrienoic acid (12-HHT), which was extracted and analyzed by RP-HPLC according to 5LOX products. The COX-1/2 inhibitor indomethacin $(10 \mu \mathrm{M}$, Sigma-Aldrich) was used as the control.

Platelet COX-1 Activity. Freshly isolated platelets $\left(1 \times 10^{8}\right)$ were preincubated with vehicle (DMSO) or $27 \mathbf{a}$ for $5 \mathrm{~min}$ at room temperature. Arachidonic acid $(5 \mu \mathrm{M})$ was added to induce 12-HHT formation. After incubation for $5 \mathrm{~min}$ at $37{ }^{\circ} \mathrm{C}, 12-\mathrm{HHT}$ was extracted and analyzed by RP-HPLC as described for 5-LOX products. The COX-1/2 inhibitor indomethacin $(10 \mu \mathrm{M})$ was used as the reference compound.

sEH Activity. Human recombinant $\mathrm{sEH}$ was expressed in Sf9 insect cells and purified by affinity chromatography. ${ }^{83}$ Briefly, Sf 9 cells were infected with a recombinant baculovirus and lysed after $72 \mathrm{~h}$ in $50 \mathrm{mM} \mathrm{NaHPO}_{4} \mathrm{pH} 8,300 \mathrm{mM} \mathrm{NaCl}, 10 \%$ glycerol, $1 \mathrm{mM}$ EDTA, 1 $\mathrm{mM}$ phenylmethanesulfonyl fluoride, $10 \mu \mathrm{g} / \mathrm{mL}$ leupeptin, and 60 $\mu \mathrm{g} / \mathrm{mL}$ STI by sonication $\left(3 \times 10 \mathrm{~s}, 4{ }^{\circ} \mathrm{C}\right)$. Sequential centrifugation at $20000 \mathrm{~g}\left(10 \mathrm{~min}, 4{ }^{\circ} \mathrm{C}\right)$ and $100000 \mathrm{~g}\left(60 \mathrm{~min}, 4{ }^{\circ} \mathrm{C}\right)$ yielded a supernatant, which was subjected to benzylthio-sepharose affinity chromatography. Elution with 4-fluorochalcone oxide in PBS pH 7.4 with $1 \mathrm{mM}$ dithiothreitol and $1 \mathrm{mM}$ EDTA yielded $\mathrm{sEH}$, which was dialyzed and concentrated.

Purified sEH $(60 \mathrm{ng})$ in $25 \mathrm{mM}$ Tris $\mathrm{HCl} \mathrm{pH} 7$ with $0.1 \mathrm{mg} / \mathrm{mL}$ bovine serum albumin (BSA) was preincubated with the vehicle (DMSO) or $27 \mathrm{a}$ for $10 \mathrm{~min}$ at room temperature. The $\mathrm{sEH}$ substrate PHOME (50 $\mu \mathrm{M}$, Cayman Chemicals) was added to start the enzymatic reaction, which was stopped after $60 \mathrm{~min}$ in darkness by addition of $\mathrm{ZnSO}_{4}(200 \mathrm{mM})$. The formation of the fluorescent product 6-methoxynaphtaldehyde was measured using a NOVOstar fluorescence microplate reader (BMG Labtech, Ortenberg, Germany), with excitation at 330 and emission at $465 \mathrm{~nm}$. The selective sEH inhibitor AUDA (100 nM, Cayman Chemicals) was used as the control.

Lipid Mediator Extraction for UPLC-MS/MS. Monocytes $(1 \times$ $\left.10^{6} / \mathrm{mL}\right)$, which were prestimulated with LPS $(1 \mu \mathrm{g} / \mathrm{mL})$ for $24 \mathrm{~h}$ to induce COX-2 expression, or M1 macrophages $\left(2 \times 10^{6}\right.$ cells $\left./ \mathrm{mL}\right)$ were preincubated with the vehicle (0.1\% DMSO), 27a, or 12a for 15 min. Arachidonic acid $(20 \mu \mathrm{M})$ and $\mathrm{A} 23187(2.5 \mu \mathrm{M})$ were added to monocytes suspended in a monocyte medium (lacking FCS if indicated) to induce lipid mediator formation. ${ }^{81}$ Macrophages were stimulated in PBS pH 7.4 (containing $1 \mathrm{mM} \mathrm{CaCl}_{2}$ ) with E. coli (serotype O6:K2:H1) at a ratio of 1:50 (macrophages: E. coli) for 180 min at $37{ }^{\circ} \mathrm{C}$ and $5 \% \mathrm{CO}_{2}{ }^{24}$

Ice-cold methanol was added to monocytes, proteins were precipitated at $-20{ }^{\circ} \mathrm{C}$, and samples were acidified $(\mathrm{pH} 3.5) .{ }^{81}$ Lipid mediators were extracted by solid-phase extraction on Sep-Pak C18 $35 \mathrm{cc}$ Vac Cartridges (Waters). After washing with $\mathrm{H}_{2} \mathrm{O}$ twice, lipid mediators were eluted with methanol and analyzed by UPLC$\mathrm{MS} / \mathrm{MS}^{81} \mathrm{PGB}_{1}$ (100 ng, Cayman Chemicals) was used as the internal standard.

Fatty acids and lipid mediators were extracted from macrophage supernatants or murine peritoneal exudates $(1 \mathrm{~mL})$ after addition of two aliquots of ice-cold methanol. ${ }^{23} d_{8}$-5S-HETE, $d_{4}$ - $\mathrm{LTB}_{4}, d_{5}$-lipoxin $\mathrm{A}_{4}, d_{5}$-resolvin $\mathrm{D}_{2}, d_{4}-\mathrm{PGE}_{2}(200 \mathrm{nM}$, each, Cayman Chemicals), and $d_{8}$-arachidonic acid $(10 \mu \mathrm{M}$, Cayman Chemicals) were added as internal standards. After protein precipitation at $-20{ }^{\circ} \mathrm{C}$ for $\geq 1 \mathrm{~h}$, supernatants $\left(1200 \mathrm{~g}, 10 \mathrm{~min}, 4{ }^{\circ} \mathrm{C}\right)$ were acidified $(\mathrm{pH} \mathrm{3.5})$ and loaded onto solid-phase cartridges (Sep-Pak Vac $6 \mathrm{cc} 500 \mathrm{mg} / 6 \mathrm{~mL}$ C18; Waters), which had been equilibrated with methanol and $\mathrm{H}_{2} \mathrm{O}$. The columns were extensively washed with $\mathrm{H}_{2} \mathrm{O}$ and hexane before lipid mediators were eluted with methyl formate, evaporated to dryness, dissolved in methanol $/ \mathrm{H}_{2} \mathrm{O}$ (50:50), and analyzed by UPLCMS/MS. ${ }^{23}$

Extraction of LCMs and Derivatives. LCMs, 27a, and 27a metabolites were extracted from PMNL, medium of the liver-on-chip, murine plasma, peritoneal exudate, or homogenized murine tissue as described. ${ }^{6}$ In brief, PBS pH 7.4, methanol, chloroform, and saline (final ratio: 14:34:35:17) were successively added together with $13 \mathrm{~d}$ 
(9 pmol) as the internal standard. The organic layer was evaporated, and the extracted LCMs were dissolved in methanol.

Liquid Chromatography and Mass Spectrometry. Lipid mediators, LCMs, 27a, and 27a metabolites were separated on an Acquity UPLC BEH C18 column $(1.7 \mu \mathrm{m}$, lipid mediators for monocytes and LCMs: $2.1 \mathrm{~mm} \times 50 \mathrm{~mm}$; otherwise, $2.1 \mathrm{~mm} \times 100$ $\mathrm{mm}$, Waters) using an Acquity UPLC system (Waters), which was coupled to a QTRAP 5500 mass spectrometer (SCIEX, Framingham, MA) equipped with an electrospray ionization source. ${ }^{6,23,81}$ Diagnostic ion fragments were detected by (scheduled) multiple reaction monitoring (MRM) in the negative ion mode.

To analyze lipid mediators produced by monocytes, a flow rate of $0.8 \mathrm{~mL} / \mathrm{min}$ and a column temperature of $45{ }^{\circ} \mathrm{C}$ were applied. Mobile phase A consisted of acetonitrile with $0.07 \%$ formic acid, and mobile phase $B$ was acetonitrile $/ \mathrm{H}_{2} \mathrm{O}(10: 90)$ with $0.07 \%$ formic acid. Isocratic elution at $\mathrm{A} / \mathrm{B}(30: 70)$ for 2 min was followed by a linear gradient to $\mathrm{A} / \mathrm{B}: 70 / 30$ within $5 \mathrm{~min}$. Data were normalized to the internal standard $\mathrm{PGB}_{1}$, which allows the comparison of signal intensities between samples but not absolute quantification.

To quantify lipid mediators and fatty acids in macrophages, murine plasma, and murine peritoneal exudates, the mobile phase methanol/ $\mathrm{H}_{2} \mathrm{O}$ (acidified with $0.01 \%$ acetic acid) was ramped from $42: 58$ to $86: 14$ over $12.5 \mathrm{~min}$, followed by isocratic elution with methanol/ $\mathrm{H}_{2} \mathrm{O}$ (98:2) for $3 \mathrm{~min}$. Absolute quantification was based on 6 internal and 45 external standards. ${ }^{23}$

LCMs, 27a, and 27a metabolites were separated at a flow rate of $0.8 \mathrm{~mL} / \mathrm{min}$ and a column temperature of $45{ }^{\circ} \mathrm{C}$, with acetonitrile/ $\mathrm{H}_{2} \mathrm{O}(10: 90)$ as mobile phase A and acetonitrile as mobile phase $\mathrm{B}$, both acidified with $0.07 \%$ formic acid. The linear gradient from $\mathrm{A} / \mathrm{B}=$ 50:50 to 0:100 within $4.5 \mathrm{~min}$ was followed by isocratic elution with $\mathrm{A} / \mathrm{B}=0: 100$ for $1 \mathrm{~min}$. MS parameters were adjusted according to Pein et al. ${ }^{6}$ and as detailed in Table S3. Signal intensities were normalized to the internal standard 13d, and concentrations were calculated using external calibration curves as specified in Table S3.

Automatic peak integration was performed with Analyst 1.6 software (Sciex) using IntelliQuan default settings.

Correlation Network Analysis. The structure-based correlation networks of LCMs and derivatives were generated with Cytoscape 3.7.2 software (Cytoscape Consortium) ${ }^{84}$ Tanimoto coefficients were calculated between the SMILES structures of compounds and represent the connecting edges in the correlation network, which is presented in an edge-weighted spring embedded layout. Nodes in close proximity represent structurally related compounds. The potency of the compounds to inhibit cell-free or cell-based 5-LOX activity is visualized by the node size, where bigger nodes represent compounds with higher inhibitory activity (lower $\mathrm{IC}_{50}$ value). The node shape illustrates the compound series, and the node color indicates the series of garcinoic acids (13a-e), amplexichromanols $(27 a-d)$, tocopherols, and tocotrienols $(1 \mathbf{a}-\mathbf{d}, 6 \mathbf{6}-\mathbf{d})$.

Multiorgan-Tissue-Flow (MOTiF) Biochips. Biochips were made from polystyrene by injection molding and were equipped with a poly(ethylene terephthalate) (PET) membrane (TRAKETCH, thickness: $12 \mu \mathrm{m}$; pore diameter: $8 \mu \mathrm{m}$; pore density: $1 \times 10^{5}$ pores/ $\mathrm{cm}^{2}$; Sabeu, Radeberg, Germany) that was integrated in the upper and lower parts of the biochip by heat-sealing with the bulk material. The top and bottom sides of the biochips and channels were sealed with an extruded PS bonding foil (thickness: $125 \mu \mathrm{m}$ ) by a lowtemperature bonding method. The upper and lower parts of the biochips were assembled using a double-sided adhesive film, and the chip surface was hydrophilized by oxygen plasma treatment to facilitate cell adhesion and prevent air bubble formation within the chambers and channels. ${ }^{85,86}$

HUVECs were isolated from human umbilical cord veins and cultivated in an endothelial cell growth medium MV (Promocell, Heidelberg, Germany) with penicillin $(100 \mathrm{U} / \mathrm{mL}) /$ streptomycin $\left(100 \mu \mathrm{g} / \mathrm{mL}\right.$, GE Healthcare) up to passage $4 .{ }^{87}$ On reaching $95 \%$ confluence, cells were subcultured at a density of $1.5 \times 10^{4}$ cells $/ \mathrm{cm}^{2}$.

HepaRG cells (Biopredic International, Rennes, France) were grown in William's medium E (Biochrom, Berlin, Germany) with $10 \%$ FCS, $5 \mu \mathrm{g} / \mathrm{mL}$ insulin (Sigma-Aldrich), $2 \mathrm{mM}$ glutamine (Thermo
Fisher Scientific), $50 \mu \mathrm{M}$ hydrocortisone-hemisuccinate (SigmaAldrich), and penicillin $(100 \mathrm{U} / \mathrm{mL}) /$ streptomycin $(100 \mu \mathrm{g} / \mathrm{mL}$, GE Healthcare) at $37{ }^{\circ} \mathrm{C}$ and $5 \% \mathrm{CO}_{2}$ for 14 days prior to differentiation with $2 \%$ DMSO for another 14 days. The medium was changed every 3-4 days, and differentiated cells were used up to 4 weeks.

The liver-on-chip was prepared by seeding HUVECs (top: $3 \times 10^{5}$, bottom: $1.5 \times 10^{5}$ ) in an endothelial cell growth medium MV on top of the membrane in the upper chamber and on the bottom of the membrane in the lower chamber, giving the cells $3-4 \mathrm{~h}$ to adhere before flipping the chip upside and seeding the bottom layer. After 2 days, differentiated HepaRG cells $\left(3 \times 10^{5}\right)$ were seeded on top of the lower and on the bottom of the upper membrane in a hepatocyte culture medium with hydrocortisone-hemisuccinate adjusted to $5 \mu \mathrm{M}$ for $24 \mathrm{~h}$ at $37{ }^{\circ} \mathrm{C}$ and $5 \% \mathrm{CO}_{2}$. The medium between the two membranes was renewed, and the vehicle (DMSO), 12a, or 27a were added. After incubation for $48 \mathrm{~h}$ at $37{ }^{\circ} \mathrm{C}$ and $5 \% \mathrm{CO}_{2}$, the medium was collected and the system was washed with $500 \mu \mathrm{L}$ of methanol. 12a, 27a, and their metabolites were extracted from the combined fractions and analyzed by UPLC-MS/MS. ${ }^{6}$

CYP3A4 Expression in Hepatocytes. HepaRG cells were seeded at a density of $2.6 \times 10^{4}$ cells $/ \mathrm{cm}^{2}$ in Williams' E medium supplemented with $2 \mathrm{mM}$ GlutaMAX (Thermo Fisher Scientific, Waltham, MA), $100 \mathrm{U} / \mathrm{mL}$ penicillin, $100 \mu \mathrm{g} / \mathrm{mL}$ streptomycin, $10 \%$ HyClone FCS (Thermo Fisher Scientific), $5 \mu \mathrm{g} / \mathrm{mL}$ insulin, and 50 $\mathrm{mM}$ hydrocortisone-hemisuccinate. At confluence after two weeks, HepaRG cells were shifted to a medium supplemented with $1.7 \%$ DMSO for two additional weeks to obtain confluent differentiated cultures containing equal proportions of hepatocyte-like and progenitors/primitive biliary-like cells. These differentiated hepatic cell cultures were exposed to the compounds in Williams' E medium supplemented with $2 \%$ FCS plus $0.2 \%$ DMSO for $48 \mathrm{~h}$.

For immunolocalization of cytochrome CYP3A4 and F-actin, cells were fixed at $4{ }^{\circ} \mathrm{C}$ with $4 \%$ paraformaldehyde for $20 \mathrm{~min}$ and permeabilized for 30 min with $0.1 \%$ saponin in PBS pH 7.4 containing $5 \%$ donkey serum. Cells were washed with PBS and incubated for 90 min with the CYP3A4 primary antibody (AB1254, Chemicon International, Temecula, CA) diluted at $1 / 800$ in PBS containing $0.1 \%$ saponin and, then, incubated for 45 min with an FITC-labeled secondary antibody (Jackson ImmunoResearch, West Grove, PA) diluted at $1 / 400$ in $0.1 \%$ saponin. F-actin was labeled by the phalloidin fluoroprobe SR101 (200 U/mL) (Interchim, Montluçon, France) diluted at $1 / 100$ for $20 \mathrm{~min}$.

The assay plate was imaged and analyzed using the Cell Health Profiling BioApplications (HCS Studio Cellomics software Version x.6.4.3 (Build 7207)) on the ArrayScan VTI HCS Reader (Thermo Fisher Scientific-Cellomics, Pittsburgh, PA) using the $20 \times$ objective (Zeiss, LD Plan Neofluar $20 \times / 0.4$ korr). Images were acquired with the Photometrics X1 CCD camera with a 14-bit dynamic range, 2208 $\times 2208$ pixel array, and $4.54 \mu \mathrm{m}$ pixel size.

The CYP3A4 expression was quantified using an arbitrary unit of fluorescent mass representing the combination of intensity and area adjusted to cell number calculated by nuclei counting (Hoechst).

Experimental Atopic Dermatitis. Compound 27a was evaluated in an inflammatory model of RHE by Synelvia S.A.S. (Labège, France) according to the company's protocol. ${ }^{88}$ In brief, primary female human keratinocytes were used to generate RHE on polycarbonate filters as described. ${ }^{88}$ RHE was allowed to acclimate for 6 days $\left(5 \% \mathrm{CO}_{2}, 37{ }^{\circ} \mathrm{C}\right)$ prior to incubation with $27 \mathbf{a}(5,10,25$ $\mu \mathrm{M})$, dexamethasone $(1 \mu \mathrm{M})$, or vehicle (0.05\% DMSO), and a proinflammatory cytokine cocktail for 4 days at $5 \% \mathrm{CO}_{2}$ and $37{ }^{\circ} \mathrm{C}$. The culture medium including compounds and cytokines was changed on days 6,8 , and 10 . Each culture condition was repeated three times. Acute cytotoxicity of $27 \mathrm{a}$ was excluded at the concentrations studied within $24 \mathrm{~h}$ by measuring the mitochondrial dehydrogenase activity (MTT assay).

Morphological changes (i.e., spongiosis and the formation of keratohyalin granules) were evaluated for sections of paraffinembedded RHEs after hematoxylin-eosin staining. ${ }^{89}$ The permeability of the skin barrier was estimated from the transepidermal water loss at 
the RHE surface. ${ }^{90}$ The surface $\mathrm{pH}$ was determined with a $\mathrm{pH}$ electrode as reported. ${ }^{89}$ The permeability of the stratum corneum was addressed by applying Lucifer yellow onto the RHE surface and inspecting the penetration by fluorescence microscopy. ${ }^{88}$ TSLP and IL-8 levels were analyzed by ELISA (according to the specifications of Synelvia S.A.S.) in the culture medium on day 2 and day 4 after addition of cytokines, respectively.

Animals. Male CD-1 mice (33-39 g, 6-8 weeks, Charles River Laboratories; Calco, Italy) and female BALB/c mice ( $20 \mathrm{~g}$, 8 weeks, Charles River Laboratories) were fed with standard rodent chow and water and acclimated for 4 days at a $12 \mathrm{~h}$ light and $12 \mathrm{~h}$ dark schedule in a constant air-conditioned environment $\left(21 \pm 2{ }^{\circ} \mathrm{C}\right)$. Mice were randomly assigned to groups, and experiments were carried out during the light phase. Experimental procedures were conducted in conformity with Italian (DL 26/2014) and European (directive 2010/ $63 / \mathrm{EU}$ ) regulations on the protection of animals used for scientific purposes and approved by the Italian Ministry.

Zymosan-Induced Peritonitis in Mice. CD-1 mice received 27a or zileuton, with DMSO $(2 \%)$ in saline $(0.5 \mathrm{~mL})$ as a vehicle for i.p. administration and carboxymethylcellulose $(0.5 \%)$ in $10 \%$ Tween 20 $(0.5 \mathrm{~mL})$ as a vehicle for p.o. administration. Zymosan $(2 \mathrm{mg} / \mathrm{mL}$ in saline, i.p., $0.5 \mathrm{~mL}$, Sigma-Aldrich) was injected at $30 \mathrm{~min}$ (i.p.) or 60 $\min$ (p.o.) post compound administration. Mice were sacrificed by inhalation of $\mathrm{CO}_{2}$ after another $30 \mathrm{~min}$ to determine $\mathrm{LTC}_{4}$ levels, lipid mediator profiles, metabolites, and vascular permeability and after $4 \mathrm{~h}$ to analyze $\mathrm{LTB}_{4}$ levels and cell infiltration. ${ }^{72}$ Plasma and peritoneal exudates were collected, and cells were counted in exudates after trypan blue staining. Vascular permeability was measured by injection of Evans blue dye $(40 \mathrm{mg} / \mathrm{kg}$ in saline, $0.3 \mathrm{~mL}$, SigmaAldrich) into the tail vain directly before peritonitis induction. ${ }^{72}$ The exudate was centrifuged $(3000 \mathrm{~g}, 5 \mathrm{~min})$, and the absorbance was measured at $610 \mathrm{~nm}$ (DU730 spectrophotometer, Beckman Coulter, Krefeld, Germany). Levels of $\mathrm{LTB}_{4}$ and cysteinyl-LTs (dominated by $\mathrm{LTC}_{4}$ ) were quantified in the exudate by ELISA (Enzo Life Sciences, Lörrach, Germany) according to the manufacturer's instructions. Compound 27a, its metabolites, and lipid mediators were extracted and analyzed by UPLC-MS/MS.

Experimental Model of Murine Asthma. BALB/c mice received 27a (p.o.) or vehicle ( $0.5 \%$ carboxymethylcellulose in $10 \%$ Tween 20; $0.5 \mathrm{~mL}$ ) on days 0 and $7,1 \mathrm{~h}$ (p.o) before being sensitized to ovalbumin ( $100 \mu \mathrm{g}$ adsorbed to $3.3 \mathrm{mg}$ of aluminum hydroxide gel, s.c., Sigma-Aldrich). Mice were sacrificed on days 1, 3, 8, 10, or 21 to collect lung and plasma. Bronchi were cut in rings of 1 to $2 \mathrm{~mm}$ length, placed in organ baths, and fixed to an isometric force transducer 7006 connected to a Powerlab 800 (AD Instruments, Ugo Basile, Comerio, Italy). After stretching the rings to a resting tension of $0.5 \mathrm{~g}$ and equilibration for at least $30 \mathrm{~min}$, the rings were challenged with carbachol $(1 \mu \mathrm{M})$ until a reproducible response was observed. To assess bronchial reactivity, the cumulative response to carbachol (0.001 to $3.16 \mu \mathrm{M})$ was measured. Bronchial relaxation was determined from the cumulative response of precontracted bronchial tissues to salbutamol. Compound $27 \mathrm{a}, \mathrm{LTB}_{4}$, and $\mathrm{LTB}_{4}$ isomers were analyzed in plasma and lung homogenates by UPLC-MS/MS. Lung tissue $(100 \mathrm{mg} / \mathrm{mL})$ was homogenized in PBS $\mathrm{pH} 7.4$ at $4{ }^{\circ} \mathrm{C}$ for $1-2$ min using an Omni tissue homogenizer (Omni, Kennesaw, GA).

Statistics. Data are presented as mean with single values or mean \pm SEM of $n$ observations, where $n$ represents the number of experiments or the number of animals, as indicated. The compound library was blinded for screening purposes but not for further biological evaluation, and samples from mouse peritoneum were blinded for counting infiltrated cells. Outliers were identified using a Grubb's test. Different groups were compared by one-way or two-way ANOVA for independent or correlated samples followed by Tukey's or Bonferroni's HSD post hoc test or by the two-tailed Student's $t$-test for paired or unpaired samples. Tests were conducted using a twosided $\alpha$ level of 0.05 . $P$ values $<0.05$ were considered statistically significant. Statistical calculations were performed using GraphPad Prism 9.1 (GraphPad Software, La Jolla, CA). IC I0 $_{50}$ values were determined by graphical analysis using SigmaPlot 14.0 (Systat Software Inc., San Jose, CA).

\section{ASSOCIATED CONTENT}

\section{Supporting Information}

The Supporting Information is available free of charge at https://pubs.acs.org/doi/10.1021/acs.jmedchem.1c00806.

Molecular formula strings of all compounds (210705 SMILES (CSV))

Inhibition of human isolated 5-LOX and 5-LOX product formation in activated PMNL by natural vitamin $\mathrm{E}$ forms and derivatives $(\mathbf{1} \mathbf{a}-\mathbf{1 1})$ (Table S1); nomenclature proposed to name natural vitamin $\mathrm{E}$ forms and $\omega$ oxidized derivatives (Table S2); conditions for the quantification of $27 \mathbf{a}$ and its metabolites by UPLC-MS/ MS (Table S3); SARs on cell-free 5-LOX inhibition ${ }^{a}$ (Scheme S1); SARs on the inhibition of 5-LOX product formation in PMNL ${ }^{\mathrm{a}}$ (Scheme S2); correlation network of the compound library for the inhibition of cell-free 5LOX (Figure S1); molecular docking simulation of 5LOX (Figure S2); fluorescence spectroscopic analysis of 5-LOX ligand interactions (Figure S3); effect of 27a on human monocyte and PBMC viability (Figure S4); compound 27a selectively inhibits 5-LOX product formation in activated monocytes (Figure S5); compound 27a attenuates cytokine-triggered defects in reconstructed human epidermis (RHE) (Figure S6); effect of 27 a on resolvin $(\mathrm{Rv}) \mathrm{E} 3$ and systemic $\mathrm{LTB}_{4}$ levels in mice with acute peritonitis (Figure S7); ${ }^{1} \mathrm{H}$ and ${ }^{13} \mathrm{C}$ NMR spectra of 49, 50, 13e, 51, 2, 4, 53, 19b, 19a, $20,21,22,55,15 b, 15 a, 25,58,14,59,16,60,17,61$, $18,65,66,26,41,40,35,36,37,38,39,42,43,67,31$, $70,48,46,68,31,69,32,62,28,63$, and 29; and HPLC-ELSD spectra of 13a, 13d, 27a, and 27d (Figures S8-S60) (PDF)

\section{AUTHOR INFORMATION}

\section{Corresponding Authors}

Oliver Werz - Department of Pharmaceutical/Medicinal Chemistry, Institute of Pharmacy, Friedrich Schiller University Jena, 07743 Jena, Germany; 이이이.org/00000002-5064-4379; Phone: +49 3641 9-49801;

Email: oliver.werz@uni-jena.de; Fax: +49 3641 9-49802

Jean-Jacques Helesbeux - Univ Angers, SONAS, SFR QUASAV, F-49000 Angers, France; Phone: +33 249180 441; Email: jean-jacques.helesbeux@univ-angers.fr Andreas Koeberle - Michael Popp Institute and Center for Molecular Biosciences Innsbruck (CMBI), University of Innsbruck, 6020 Innsbruck, Austria; Department of Pharmaceutical/Medicinal Chemistry, Institute of Pharmacy, Friedrich Schiller University Jena, 07743 Jena, Germany; ○ orcid.org/0000-0001-6269-5088; Phone: +43 512 50757903; Email: andreas.koeberle@uibk.ac.at

\section{Authors}

Konstantin Neukirch - Michael Popp Institute and Center for Molecular Biosciences Innsbruck (CMBI), University of Innsbruck, 6020 Innsbruck, Austria; Department of Pharmaceutical/Medicinal Chemistry, Institute of Pharmacy, Friedrich Schiller University Jena, 07743 Jena, Germany; - orcid.org/0000-0003-0630-1624

Khaled Alsabil - Univ Angers, SONAS, SFR QUASAV, F49000 Angers, France

Chau-Phi Dinh - Univ Angers, SONAS, SFR QUASAV, F49000 Angers, France; Present Address: Univ. Lille, 
Inserm, Institut Pasteur de Lille, U1177 - Drugs and Molecules for Living Systems, EGID, F-59000 Lille, France. Email: chauphi.dinh@univ-lille.fr

Rossella Bilancia - Department of Pharmacy, School of Medicine and Surgery, University of Naples Federico II, 80131 Naples, Italy

Martin Raasch - Institute of Biochemistry II, Jena University Hospital, 07747 Jena, Germany

Alexia Ville - Univ Angers, SONAS, SFR QUASAV, F-49000 Angers, France; Present Address: Laboratoire COBRA, 1, rue Tesnière, 76821 Mont-Saint-Aignan cedex, France. Email: alexia.ville@univ-rouen.fr.

Ida Cerqua - Department of Pharmacy, School of Medicine and Surgery, University of Naples Federico II, 80131 Naples, Italy

Guillaume Viault - Univ Angers, SONAS, SFR QUASAV, F49000 Angers, France

Dimitri Bréard - Univ Angers, SONAS, SFR QUASAV, F49000 Angers, France

Simona Pace - Department of Pharmaceutical/Medicinal Chemistry, Institute of Pharmacy, Friedrich Schiller University Jena, 07743 Jena, Germany

Veronika Temml - Department of Pharmaceutical and Medicinal Chemistry, Paracelsus Medical University Salzburg, 5020 Salzburg, Austria

Elena Brunner - Department of Pharmaceutical/Medicinal Chemistry, Institute of Pharmacy, Friedrich Schiller University Jena, 07743 Jena, Germany

Paul M. Jordan - Department of Pharmaceutical/Medicinal Chemistry, Institute of Pharmacy, Friedrich Schiller University Jena, 07743 Jena, Germany

Marta C. Marques - Instituto de Medicina Molecular João Lobo Antunes, Faculdade de Medicina, Universidade de Lisboa, 1649-028 Lisboa, Portugal

Konstantin Loeser - Department of Pharmaceutical/ Medicinal Chemistry, Institute of Pharmacy, Friedrich Schiller University Jena, 07743 Jena, Germany

André Gollowitzer - Michael Popp Institute and Center for Molecular Biosciences Innsbruck (CMBI), University of Innsbruck, 6020 Innsbruck, Austria; Department of Pharmaceutical/Medicinal Chemistry, Institute of Pharmacy, Friedrich Schiller University Jena, 07743 Jena, Germany

Stephan Permann - Michael Popp Institute and Center for Molecular Biosciences Innsbruck (CMBI), University of Innsbruck, 6020 Innsbruck, Austria

Jana Gerstmeier - Department of Pharmaceutical/Medicinal Chemistry, Institute of Pharmacy, Friedrich Schiller University Jena, 07743 Jena, Germany

Stefan Lorkowski - Department of Nutritional Biochemistry and Physiology, Institute of Nutritional Science and Competence Cluster for Nutrition and Cardiovascular Health (nutriCARD), Halle-Jena-Leipzig, Friedrich Schiller University Jena, 07743 Jena, Germany

Hermann Stuppner - Institute of Pharmacy/Pharmacognosy and Center for Molecular Biosciences Innsbruck (CMBI), University of Innsbruck, 6020 Innsbruck, Austria; () orcid.org/0000-0001-8862-0201

Ulrike Garscha - Department of Pharmaceutical/Medicinal Chemistry, Institute of Pharmacy, University of Greifswald, 17489 Greifswald, Germany

Tiago Rodrigues - Instituto de Medicina Molecular João Lobo Antunes, Faculdade de Medicina, Universidade de Lisboa, 1649-028 Lisboa, Portugal
Gonçalo J. L. Bernardes - Instituto de Medicina Molecular João Lobo Antunes, Faculdade de Medicina, Universidade de Lisboa, 1649-028 Lisboa, Portugal; Department of Chemistry, University of Cambridge, CB2 1EW Cambridge, U.K.; 10 orcid.org/0000-0001-6594-8917

Daniela Schuster - Department of Pharmaceutical and Medicinal Chemistry, Paracelsus Medical University Salzburg, 5020 Salzburg, Austria; 이이이.org/0000-00029933-8938

Denis Séraphin - Univ Angers, SONAS, SFR QUASAV, F-

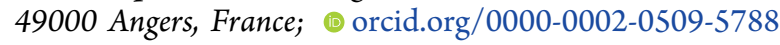

Pascal Richomme - Univ Angers, SONAS, SFR QUASAV, F49000 Angers, France

Antonietta Rossi - Department of Pharmacy, School of Medicine and Surgery, University of Naples Federico II, 80131 Naples, Italy

Alexander S. Mosig - Institute of Biochemistry II, Jena University Hospital, 07747 Jena, Germany; 이이.org/ 0000-0002-5687-2444

Fiorentina Roviezzo - Department of Pharmacy, School of Medicine and Surgery, University of Naples Federico II, 80131 Naples, Italy

Complete contact information is available at:

https://pubs.acs.org/10.1021/acs.jmedchem.1c00806

\section{Author Contributions}

"K.N. and K.A. contributed equally.

\section{Funding}

A.K. was supported by the Austrian Science Fund (I4968-B), the German Research Council (KO 4589/7-1, GRK 1715), and the German Academic Exchange Service (57389523) paid from the German Federal Ministry of Education and Research. O.W. was funded by the Deutsche Forschungsgemeinschaft (DFG, German Research Foundation) WE 2260/14-1, project-ID 316213987 - SFB 1278 PolyTarget (projects A04, C02) and - project-ID 239748522 - SFB 1127 ChemBioSys (project A04) and by the Free State of Thuringia and the European Social Fund (2019 FGR 0095). S.L. was supported by the German Research Council (GRK 1715) and by the Free State of Thuringia and the European Social Fund (2019 FGR 0095). Works of D.S., G.V., K.A., J.-J.H., and P.R. were supported by the National Research Agency (ANR-19-CE180033-01). A.R and F.R. were supported by the Ministero della Università e della Ricerca (MUR; 000005 FFABR_2017_A_Rossi_001_001; 000005_FFABR_2017_A_Roviezzo_001_001). U.G. was funded by the German Research Council (GA 2101/2-1).

\section{Notes}

The authors declare no competing financial interest.

\section{ACKNOWLEDGMENTS}

The authors are grateful to the North and South Provinces of New Caledonia who facilitated our field investigation, as well as to Marc Litaudon, Vincent Dumontet, and Cyril Poulain for G. amplexicaulis sample collection. Moreover, the authors thank Katrin Fischer, Verena Krauth, Monika Listing, Erik Romp, Bärbel Schmalwasser, Alrun Schumann, Heidi Traber, and Petra Wiecha for technical assistance in performing experiments. This research was funded in part by the Austrian Science Fund (FWF) (I4968-B). For the purpose of open access, the author has applied a CC BY public copyright license 
to any Author Accepted Manuscript version arising from this submission.

\section{ABBREVIATIONS USED}

COX, cyclooxygenase; cPLA ${ }_{2}$, cytosolic phospholipase $\mathrm{A}_{2}$; $\mathrm{DPPH}$, 2,2-diphenyl-1-picrylhydrazyl; FLAP, 5-lipoxygenaseactivating protein; fMLP, $N$-formyl-methionyl-leucyl-phenylalanine; H(P)ETE, hydro(pero)xyeicosatetraenoic acid; HDHA, hydroxydocosahexaenoic acid; HEPE, hydroxyeicosapentaenoic acid; HETE, hydroxyeicosatetraenoic acid; HUVEC, human umbilical vein endothelial cells; IL, interleukin; iNOS, inducible nitric oxide synthase; LCM, long-chain vitamin $\mathrm{E}$ metabolite; $\mathrm{LDH}$, lactate dehydrogenase; LOX, lipoxygenase; LPS, lipopolysaccharide; LT, leukotriene; mPGES-1, microsomal prostaglandin $\mathrm{E}_{2}$ synthase-1; MTT, 3(4,5-dimethylthiazol-2-yl)-2,5-diphenyltetrazolium bromide; NAFLD, nonalcoholic fatty liver disease; PBMC, peripheral blood mononuclear cells; PG, prostaglandin; PMNL, polymorphonuclear leukocytes; RHE, reconstructed human epidermis; sEH, soluble expoxide hydrolase; TSLP, thymic stromal lymphopoietin

\section{REFERENCES}

(1) Meydani, M. Vitamin E. Lancet 1995, 345, 170-175.

(2) Mesmin, B.; Antonny, B. Cell biology. Vitamin currency in a lipid exchange market. Science 2013, 340, 1051-1052.

(3) Huang, J.; Weinstein, S. J.; Yu, K.; Mannisto, S.; Albanes, D. Relationship between serum alpha-tocopherol and overall and causespecific mortality. Circ. Res. 2019, 125, 29-40.

(4) Lopes Da Silva, S.; Vellas, B.; Elemans, S.; Luchsinger, J.; Kamphuis, P.; Yaffe, K.; Sijben, J.; Groenendijk, M.; Stijnen, T. Plasma nutrient status of patients with alzheimer's disease: Systematic review and meta-analysis. Alzheimers Dement 2014, 10, 485-502.

(5) Dysken, M. W.; Sano, M.; Asthana, S.; Vertrees, J. E.; Pallaki, M.; Llorente, M.; Love, S.; Schellenberg, G. D.; Mccarten, J. R.; Malphurs, J.; Prieto, S.; Chen, P.; Loreck, D. J.; Trapp, G.; Bakshi, R. S.; Mintzer, J. E.; Heidebrink, J. L.; Vidal-Cardona, A.; Arroyo, L. M.; Cruz, A. R.; Zachariah, S.; Kowall, N. W.; Chopra, M. P.; Craft, S.; Thielke, S.; Turvey, C. L.; Woodman, C.; Monnell, K. A.; Gordon, K.; Tomaska, J.; Segal, Y.; Peduzzi, P. N.; Guarino, P. D. Effect of vitamin E and memantine on functional decline in alzheimer disease: The team-ad va cooperative randomized trial. JAMA 2014, 311, 33-44.

(6) Pein, H.; Ville, A.; Pace, S.; Temml, V.; Garscha, U.; Raasch, M.; Alsabil, K.; Viault, G.; Dinh, C. P.; Guilet, D.; Troisi, F.; Neukirch, K.; Konig, S.; Bilancia, R.; Waltenberger, B.; Stuppner, H.; Wallert, M.; Lorkowski, S.; Weinigel, C.; Rummler, S.; Birringer, M.; Roviezzo, F.; Sautebin, L.; Helesbeux, J. J.; Seraphin, D.; Mosig, A. S.; Schuster, D.; Rossi, A.; Richomme, P.; Werz, O.; Koeberle, A. Endogenous metabolites of vitamin $\mathrm{E}$ limit inflammation by targeting 5lipoxygenase. Nat. Commun. 2018, 9, No. 3834.

(7) Wallert, M.; Kluge, S.; Schubert, M.; Koeberle, A.; Werz, O.; Birringer, M.; Lorkowski, S. Natural 6-hydroxy-chromanols and -chromenols and respective derivatives as an emerging class of antiinflammatory and anti-carcinogenic agents. Front. Pharmacol. 2020, in revision..

(8) Galli, F.; Azzi, A.; Birringer, M.; Cook-Mills, J. M.; Eggersdorfer, M.; Frank, J.; Cruciani, G.; Lorkowski, S.; Ozer, N. K. Vitamin E: Emerging aspects and new directions. Free Radic. Biol. Med. 2017, $102,16-36$.

(9) Wallert, M.; Mosig, S.; Rennert, K.; Funke, H.; Ristow, M.; Pellegrino, R. M.; Cruciani, G.; Galli, F.; Lorkowski, S.; Birringer, M. Long-chain metabolites of alpha-tocopherol occur in human serum and inhibit macrophage foam cell formation in vitro. Free Radic. Biol. Med. 2014, 68, 43-51.
(10) Thompson, I. M., Jr.; Cabang, A. B.; Wargovich, M. J. Future directions in the prevention of prostate cancer. Nat. Rev. Clin. Oncol. 2014, 11, 49-60.

(11) Schmitt, C. A. Prevention: Vitamin E leaves bitter aftertaste. Nat. Rev. Clin. Oncol. 2011, 8, 692.

(12) Rinella, M. E. Nonalcoholic fatty liver disease: A systematic review. JAMA 2015, 313, 2263-2273.

(13) Funk, C. D. Prostaglandins and leukotrienes: Advances in eicosanoid biology. Science 2001, 294, 1871-1875.

(14) Haeggström, J. Z. Leukotriene biosynthetic enzymes as therapeutic targets. J. Clin. Invest. 2018, 128, 2680-2690.

(15) Peters-Golden, M.; Henderson, W. R., Jr. Leukotrienes. N. Engl. J. Med. 2007, 357, 1841-1854.

(16) Radmark, O.; Werz, O.; Steinhilber, D.; Samuelsson, B. 5lipoxygenase, a key enzyme for leukotriene biosynthesis in health and disease. Biochim. Biophys. Acta, Mol. Cell Biol. Lipids 2015, 1851, 331339.

(17) Dixon, R. A.; Diehl, R. E.; Opas, E.; Rands, E.; Vickers, P. J.; Evans, J. F.; Gillard, J. W.; Miller, D. K. Requirement of a 5lipoxygenase-activating protein for leukotriene synthesis. Nature 1990, $343,282-284$

(18) Wculek, S. K.; Malanchi, I. Neutrophils support lung colonization of metastasis-initiating breast cancer cells. Nature 2015, 528, 413-417.

(19) Wang, D.; Dubois, R. N. Eicosanoids and cancer. Nat. Rev. Cancer 2010, 10, 181-193.

(20) Martínez-Clemente, M.; Ferre, N.; Gonzalez-Periz, A.; LopezParra, M.; Horrillo, R.; Titos, E.; Moran-Salvador, E.; Miquel, R.; Arroyo, V.; Funk, C. D.; Claria, J. 5-lipoxygenase deficiency reduces hepatic inflammation and tumor necrosis factor alpha-induced hepatocyte damage in hyperlipidemia-prone apoe-null mice. Hepatology 2010, 51, 817-827.

(21) Fredman, G.; Hellmann, J.; Proto, J. D.; Kuriakose, G.; Colas, R. A.; Dorweiler, B.; Connolly, E. S.; Solomon, R.; Jones, D. M.; Heyer, E. J.; Spite, M.; Tabas, I. An imbalance between specialized pro-resolving lipid mediators and pro-inflammatory leukotrienes promotes instability of atherosclerotic plaques. Nat. Commun. 2016, 7, No. 12859

(22) Serhan, C. N. Pro-resolving lipid mediators are leads for resolution physiology. Nature 2014, 510, 92-101.

(23) Werz, O.; Gerstmeier, J.; Libreros, S.; De La Rosa, X.; Werner, M.; Norris, P. C.; Chiang, N.; Serhan, C. N. Human macrophages differentially produce specific resolvin or leukotriene signals that depend on bacterial pathogenicity. Nat. Commun. 2018, 9, No. 59.

(24) Werner, M.; Jordan, P. M.; Romp, E.; Czapka, A.; Rao, Z.; Kretzer, C.; Koeberle, A.; Garscha, U.; Pace, S.; Claesson, H. E.; Serhan, C. N.; Werz, O.; Gerstmeier, J. Targeting biosynthetic networks of the proinflammatory and proresolving lipid metabolome. FASEB J. 2019, 33, 6140-6153.

(25) Bartolini, D.; De Franco, F.; Torquato, P.; Marinelli, R.; Cerra, B.; Ronchetti, R.; Schon, A.; Fallarino, F.; De Luca, A.; Bellezza, G.; Ferri, I.; Sidoni, A.; Walton, W. G.; Pellock, S. J.; Redinbo, M. R.; Mani, S.; Pellicciari, R.; Gioiello, A.; Galli, F. Garcinoic acid is a natural and selective agonist of pregnane $\mathrm{x}$ receptor. J. Med. Chem. 2020, 63, 3701-3712.

(26) Willems, S.; Gellrich, L.; Chaikuad, A.; Kluge, S.; Werz, O.; Heering, J.; Knapp, S.; Lorkowski, S.; Schubert-Zsilavecz, M.; Merk, D. Endogenous vitamin E metabolites mediate allosteric ppargamma activation with unprecedented co-regulatory interactions. Cell Chem. Biol. 2021, DOI: 10.1016/j.chembiol.2021.04.019.

(27) Marinelli, R.; Torquato, P.; Bartolini, D.; Mas-Bargues, C.; Bellezza, G.; Gioiello, A.; Borras, C.; De Luca, A.; Fallarino, F.; Sebastiani, B.; Mani, S.; Sidoni, A.; Vina, J.; Leri, M.; Bucciantini, M.; Nardiello, P.; Casamenti, F.; Galli, F. Garcinoic acid prevents betaamyloid (abeta) deposition in the mouse brain. J. Biol. Chem. 2020, 295, 11866-11876.

(28) Schmölz, L.; Wallert, M.; Rozzino, N.; Cignarella, A.; Galli, F.; Glei, M.; Werz, O.; Koeberle, A.; Birringer, M.; Lorkowski, S. Structure-function relationship studies in vitro reveal distinct and 
specific effects of long-chain metabolites of vitamin E. Mol. Nutr. Food Res. 2017, 61, No. 1700562.

(29) Ciffolilli, S.; Wallert, M.; Bartolini, D.; Krauth, V.; Werz, O.; Piroddi, M.; Sebastiani, B.; Torquato, P.; Lorkowski, S.; Birringer, M.; Galli, F. Human serum determination and in vitro anti-inflammatory activity of the vitamin E metabolite alpha-(13'-hydroxy)-6-hydroxychroman. Free Radic. Biol. Med. 2015, 89, 952-962.

(30) Wallert, M.; Schmolz, L.; Koeberle, A.; Krauth, V.; Glei, M.; Galli, F.; Werz, O.; Birringer, M.; Lorkowski, S. Alpha-tocopherol long-chain metabolite alpha-13'-COOH affects the inflammatory response of lipopolysaccharide-activated murine RAW264.7 macrophages. Mol. Nutr. Food Res. 2015, 59, 1524-1534.

(31) Jiang, Q.; Yin, X.; Lill, M. A.; Danielson, M. L.; Freiser, H.; Huang, J. Long-chain carboxychromanols, metabolites of vitamin E, are potent inhibitors of cyclooxygenases. Proc. Natl. Acad. Sci. U.S.A. 2008, 105, 20464-20469.

(32) Alsabil, K.; Suor-Cherer, S.; Koeberle, A.; Viault, G.; Lavaud, A.; Temml, V.; Waltenberger, B.; Schuster, D.; Litaudon, M.; Lorkowski, S.; De Vaumas, R.; Helesbeux, J. J.; Guilet, D.; Stuppner, H.; Werz, O.; Seraphin, D.; Richomme, P. Semisynthetic and natural garcinoic acid isoforms as new mPGES-1 inhibitors. Planta Med. 2016, 82, 1110-1116.

(33) Samuelsson, B.; Morgenstern, R.; Jakobsson, P. J. Membrane prostaglandin e synthase-1: A novel therapeutic target. Pharmacol. Rev. 2007, 59, 207-224.

(34) Koeberle, A.; Laufer, S. A.; Werz, O. Design and development of microsomal prostaglandin E2 synthase-1 inhibitors: Challenges and future directions. J. Med. Chem. 2016, 59, 5970-5986.

(35) Wallert, M.; Bauer, J.; Kluge, S.; Schmolz, L.; Chen, Y. C.; Ziegler, M.; Searle, A. K.; Maxones, A.; Schubert, M.; Thurmer, M.; Pein, H.; Koeberle, A.; Werz, O.; Birringer, M.; Peter, K.; Lorkowski, $\mathrm{S}$. The vitamin E derivative garcinoic acid from Garcinia kola nut seeds attenuates the inflammatory response. Redox Biol. 2019, 24, No. 101166.

(36) Koeberle, A.; Northoff, H.; Werz, O. Identification of 5lipoxygenase and microsomal prostaglandin e2 synthase- 1 as functional targets of the anti-inflammatory and anti-carcinogenic garcinol. Biochem. Pharmacol. 2009, 77, 1513-1521.

(37) Reques, F. G.; Rodriguez, J. L. Tolerability of leukotriene modifiers in asthma: A review of clinical experience. Biodrugs 1999, $11,385-394$.

(38) Alsabil, K.; Viault, G.; Suor-Cherer, S.; Helesbeux, J. J.; Merza, J.; Dumontet, V.; Peña-Rodriguez, L. M.; Richomme, P.; Séraphin, D. Efficient ortho-formylation in vitamin $\mathrm{E}$ series, application to the semi-synthesis of natural 5 - and 7 -formyl- $\delta$-tocotrienols revealing an unprecedented 5-bromo-7-formyl exchange. Tetrahedron 2017, 73, 6863-6870.

(39) Ville, A.; Viault, G.; Helesbeux, J. J.; Guilet, D.; Richomme, P.; Seraphin, D. Efficient semi-synthesis of natural delta-(r)-tocotrienols from a renewable vegetal source. J. Nat. Prod. 2019, 82, 51-58.

(40) Terashima, K.; Shimamura, T.; Tanabayashi, M.; Aqil, M.; Akinniyi, J. A.; Niwa, M. Constituents of the seeds of Garcinia kola: Two new antioxidants, garcinoic acid and garcinal. Heterocycles 1997, $45,1559-1566$.

(41) Lavaud, A.; Richomme, P.; Litaudon, M.; Andriantsitohaina, R.; Guilet, D. Antiangiogenic tocotrienol derivatives from Garcinia amplexicaulis. J. Nat. Prod. 2013, 76, 2246-2252.

(42) Dinh, C. P.; Ville, A.; Neukirch, K.; Viault, G.; Temml, V.; Koeberle, A.; Werz, O.; Schuster, D.; Stuppner, H.; Richomme, P.; Helesbeux, J. J.; Seraphin, D. Structure-based design, semi-synthesis and anti-inflammatory activity of tocotrienolic amides as 5-lipoxygenase inhibitors. Eur. J. Med. Chem. 2020, 202, No. 112518.

(43) Richomme, P.; Helesbeux, J. J.; Guilet, D.; Seraphin, D.; Stuppner, H.; Waltenberger, B.; Schuster, D.; Temml Veronika, S.; Koeberle, A.; Werz, O. Tocotrienol Derivatives, Pharmaceutical Composition and Method of Use in 5-Lipoxygenase Related Diseases. WO2017/032881A12017.
(44) Monache, F. D.; Marta, M.; Mac-Quhae, M. M.; Nicoletti, M. Two new tocotrienoloic acids from the fruits of clusia grandiflora splith. Gazz. Chim. Ital. 1984, 114, 135-137.

(45) Hofsløkken, N. U.; Skattebøl, L.; Johansson, F.; Bertilsson, S. K.; Andersson, P. G.; Møller, J.; Senning, A.; Yao, X.-K.; Wang, H.-G.; Tuchagues, J. P.; Ögren, M. Convenient method for the orthoformylation of phenols. Acta Chem. Scand. 1999, 53, 258-262.

(46) Behery, F. A.; Akl, M. R.; Ananthula, S.; Parajuli, P.; Sylvester, P. W.; El Sayed, K. A. Optimization of tocotrienols as antiproliferative and antimigratory leads. Eur. J. Med. Chem. 2013, 59, 329-341.

(47) Viault, G.; Kempf, M.; Ville, A.; Alsabil, K.; Perrot, R.; Richomme, P.; Helesbeux, J. J.; Seraphin, D. Semisynthetic vitamin E derivatives as potent antibacterial agents against resistant grampositive pathogens. ChemMedChem 2021, 16, 881-890.

(48) Dallacker, F.; Eisbach, R.; Holschbach, M. Derivatives in the vitamin E series. Part 1. Synthesis and reactions of all-rac-5-formyl- $\gamma$ tocopherol (i). Chem. Ztg. 1991, 115, 285-289.

(49) Fronza, G.; Fuganti, C.; Serra, S. Stereochemical course of baker's yeast mediated reduction of the tri- and tetrasubstituted double bonds of substituted cinnamaldehydes. Eur. J. Org. Chem. 2009, 2009, 6160-6171.

(50) Ohtsuka, Y.; Ikeno, T.; Yamada, T. Catalytic enantioselective protonation of cobalt-enolate equivalents generated by 1,4-reduction with borohydride. Tetrahedron: Asymmetry 2003, 14, 967-970.

(51) Mahoney, W. S.; Brestensky, D. M.; Stryker, J. M. Selective hydride-mediated conjugate reduction of alpha,beta-unsaturated carbonyl-compounds using $[(\mathrm{ph} 3 \mathrm{p}) \mathrm{cuh}] 6$. J. Am. Chem. Soc. 1988, 110, 291-293.

(52) Kwon Youn, I.; Hwan Yon, G.; Siek Pak, C. Magnesiummethanol as a simple convenient reducing agent for $\alpha, \beta$-unsaturated esters. Tetrahedron Lett. 1986, 27, 2409-2410.

(53) Lee, G. H.; Youn, I. K.; Choi, E. B.; Lee, H. K.; Yon, G. H.; Yang, H. C.; Pak, C. S. Magnesium in methanol $(\mathrm{Mg} / \mathrm{MeOH})$ in organic syntheses. Curr. Org. Chem. 2004, 8, 1263-1287.

(54) Terashima, K.; Takaya, Y.; Niwa, M. Powerful antioxidative agents based on garcinoic acid from Garcinia kola. Bioorg. Med. Chem. 2002, 10, 1619-1625.

(55) Furstner, A. Olefin metathesis and beyond. Angew. Chem., Int. Ed. 2000, 39, 3012-3043.

(56) Ville, A. Métabolites secondaires et analogues hémisynthétiques en série vitaminique E: Obtention et évaluation du potentiel antiinflammatoire. Dissertation, University of Angers, 2018.

(57) Gujarathi, S.; Zafar, M. K.; Liu, X.; Eoff, R. L.; Zheng, G. A facile semisynthesis and evaluation of garcinoic acid and its analogs for the inhibition of human DNA polymerase beta. Molecules 2020, 25, No. 5847.

(58) Roman, G. Mannich bases in medicinal chemistry and drug design. Eur. J. Med. Chem. 2015, 89, 743-816.

(59) Maria, K.; Dimitra, H. L.; Maria, G. Synthesis and antiinflammatory activity of chalcones and related mannich bases. Med. Chem. 2008, 4, 586-596.

(60) Chen, W.; Park, S. K.; Yu, W.; Xiong, A.; Sanders, B. G.; Kline, $\mathrm{K}$. Synthesis and screening of novel vitamin $\mathrm{E}$ derivatives for anticancer functions. Eur. J. Med. Chem. 2012, 58, 72-83.

(61) Behery, F. A.; Elnagar, A. Y.; Akl, M. R.; Wali, V. B.; Abuasal, B.; Kaddoumi, A.; Sylvester, P. W.; El Sayed, K. A. Redox-silent tocotrienol esters as breast cancer proliferation and migration inhibitors. Bioorg. Med. Chem. 2010, 18, 8066-8075.

(62) Werz, O. Inhibition of 5-lipoxygenase product synthesis by natural compounds of plant origin. Planta Med. 2007, 73, 1331-1357.

(63) Locowicz, J. Principles of Fluorescence Spectroscopy, 3rd ed.; Springer, 2006.

(64) Jiang, Z.; Yin, X.; Jiang, Q. Natural forms of vitamin E and 13'carboxychromanol, a long-chain vitamin $\mathrm{E}$ metabolite, inhibit leukotriene generation from stimulated neutrophils by blocking calcium influx and suppressing 5-lipoxygenase activity, respectively. J. Immunol. 2011, 186, 1173-1179. 
(65) Koeberle, A.; Werz, O. Multi-target approach for natural products in inflammation. Drug Discovery Today 2014, 19, 18711882.

(66) Shimizu, T. Lipid mediators in health and disease: Enzymes and receptors as therapeutic targets for the regulation of immunity and inflammation. Annu. Rev. Pharmacol. Toxicol. 2009, 49, 123-150.

(67) Yanes, D. A.; Mosser-Goldfarb, J. L. Emerging therapies for atopic dermatitis: The prostaglandin/leukotriene pathway. J. Am. Acad. Dermatol. 2018, 78, S71-S75.

(68) Dainichi, T.; Kitoh, A.; Otsuka, A.; Nakajima, S.; Nomura, T.; Kaplan, D. H.; Kabashima, K. The epithelial immune microenvironment (eime) in atopic dermatitis and psoriasis. Nat. Immunol. 2018, 19, 1286-1298.

(69) Siracusa, M. C.; Saenz, S. A.; Hill, D. A.; Kim, B. S.; Headley, M. B.; Doering, T. A.; Wherry, E. J.; Jessup, H. K.; Siegel, L. A.; Kambayashi, T.; Dudek, E. C.; Kubo, M.; Cianferoni, A.; Spergel, J. M.; Ziegler, S. F.; Comeau, M. R.; Artis, D. Tslp promotes interleukin3 -independent basophil haematopoiesis and type 2 inflammation. Nature 2011, 477, 229-233.

(70) Weidinger, S.; Beck, L. A.; Bieber, T.; Kabashima, K.; Irvine, A. D. Atopic dermatitis. Nat. Rev. Dis. Primers 2018, 4, No. 1.

(71) Hachem, J. P.; Crumrine, D.; Fluhr, J.; Brown, B. E.; Feingold, K. R.; Elias, P. M. Ph directly regulates epidermal permeability barrier homeostasis, and stratum corneum integrity/cohesion. J. Invest. Dermatol. 2003, 121, 345-353.

(72) Hanke, T.; Dehm, F.; Liening, S.; Popella, S. D.; Maczewsky, J.; Pillong, M.; Kunze, J.; Weinigel, C.; Barz, D.; Kaiser, A.; Wurglics, M.; Lammerhofer, M.; Schneider, G.; Sautebin, L.; Schubert-Zsilavecz, M.; Werz, O. Aminothiazole-featured pirinixic acid derivatives as dual 5-lipoxygenase and microsomal prostaglandin e2 synthase- 1 inhibitors with improved potency and efficiency in vivo. J. Med. Chem. 2013, 56, 9031-9044.

(73) Yokomizo, T.; Nakamura, M.; Shimizu, T. Leukotriene receptors as potential therapeutic targets. J. Clin. Invest. 2018, 128, 2691-2701.

(74) Diez-Roux, G.; Ballabio, A. Sulfatases and human disease. Annu. Rev. Genomics Hum. Genet. 2005, 6, 355-379.

(75) Fischer, L.; Szellas, D.; Radmark, O.; Steinhilber, D.; Werz, O. Phosphorylation- and stimulus-dependent inhibition of cellular 5lipoxygenase activity by nonredox-type inhibitors. FASEB J. 2003, 17, 949-951.

(76) Pergola, C.; Dodt, G.; Rossi, A.; Neunhoeffer, E.; Lawrenz, B.; Northoff, H.; Samuelsson, B.; Radmark, O.; Sautebin, L.; Werz, O. Erk-mediated regulation of leukotriene biosynthesis by androgens: A molecular basis for gender differences in inflammation and asthma. Proc. Natl. Acad. Sci. U.S.A. 2008, 105, 19881-19886.

(77) Verdonk, M. L.; Cole, J. C.; Hartshorn, M. J.; Murray, C. W.; Taylor, R. D. Improved protein-ligand docking using gold. Proteins 2003, 52, 609-623.

(78) Gilbert, N. C.; Bartlett, S. G.; Waight, M. T.; Neau, D. B.; Boeglin, W. E.; Brash, A. R.; Newcomer, M. E. The structure of human 5-lipoxygenase. Science 2011, 331, 217-219.

(79) Guner, O.; Clement, O.; Kurogi, Y. Pharmacophore modeling and three dimensional database searching for drug design using catalyst: Recent advances. Curr. Med. Chem. 2004, 11, 2991-3005.

(80) Wolber, G.; Langer, T. Ligandscout: 3-d pharmacophores derived from protein-bound ligands and their use as virtual screening filters. J. Chem. Inf. Model. 2005, 45, 160-169.

(81) Koeberle, A.; Munoz, E.; Appendino, G. B.; Minassi, A.; Pace, S.; Rossi, A.; Weinigel, C.; Barz, D.; Sautebin, L.; Caprioglio, D.; Collado, J. A.; Werz, O. Sar studies on curcumin's pro-inflammatory targets: Discovery of prenylated pyrazolocurcuminoids as potent and selective novel inhibitors of 5-lipoxygenase. J. Med. Chem. 2014, 57, $5638-5648$.

(82) Liedtke, A. J.; Keck, P. R.; Lehmann, F.; Koeberle, A.; Werz, O.; Laufer, S. A. Arylpyrrolizines as inhibitors of microsomal prostaglandin e2 synthase-1 (mPGES-1) or as dual inhibitors of mPGES-1 and 5-lipoxygenase (5-LOX). J. Med. Chem. 2009, 52, 4968-4972.
(83) Garscha, U.; Romp, E.; Pace, S.; Rossi, A.; Temml, V.; Schuster, D.; Konig, S.; Gerstmeier, J.; Liening, S.; Werner, M.; Atze, H.; Wittmann, S.; Weinigel, C.; Rummler, S.; Scriba, G. K.; Sautebin, L.; Werz, O. Pharmacological profile and efficiency in vivo of diflapolin, the first dual inhibitor of 5-lipoxygenase-activating protein and soluble epoxide hydrolase. Sci. Rep. 2017, 7, No. 9398.

(84) Shannon, P.; Markiel, A.; Ozier, O.; Baliga, N. S.; Wang, J. T.; Ramage, D.; Amin, N.; Schwikowski, B.; Ideker, T. Cytoscape: A software environment for integrated models of biomolecular interaction networks. Genome Res. 2003, 13, 2498-2504.

(85) Raasch, M.; Rennert, K.; Jahn, T.; Peters, S.; Henkel, T.; Huber, O.; Schulz, I.; Becker, H.; Lorkowski, S.; Funke, H.; Mosig, A. Microfluidically supported biochip design for culture of endothelial cell layers with improved perfusion conditions. Biofabrication 2015, 7, No. 015013.

(86) Raasch, M.; Rennert, K.; Jahn, T.; Gartner, C.; Schonfelder, G.; Huber, O.; Seiler, A. E.; Mosig, A. S. An integrative microfluidically supported in vitro model of an endothelial barrier combined with cortical spheroids simulates effects of neuroinflammation in neocortex development. Biomicrofluidics 2016, 10, No. 044102.

(87) Jaffe, E. A.; Nachman, R. L.; Becker, C. G.; Minick, C. R. Culture of human endothelial cells derived from umbilical veins. Identification by morphologic and immunologic criteria. J. Clin. Invest. 1973, 52, 2745-2756.

(88) Pendaries, V.; Malaisse, J.; Pellerin, L.; Le Lamer, M.; Nachat, R.; Kezic, S.; Schmitt, A. M.; Paul, C.; Poumay, Y.; Serre, G.; Simon, M. Knockdown of filaggrin in a three-dimensional reconstructed human epidermis impairs keratinocyte differentiation. J. Invest. Dermatol. 2014, 134, 2938-2946.

(89) Pendaries, V.; Lamer, Le.; Cau, M.; Hansmann, L.; Malaisse, B.; Kezic, J.; Serre, S.; Simon, G. M. In a three-dimensional reconstructed human epidermis filaggrin-2 is essential for proper cornification. Cell Death Dis. 2015, 6, No. e1656.

(90) Reynier, M.; Allart, S.; Gaspard, E.; Moga, A.; Goudouneche, D.; Serre, G.; Simon, M.; Leprince, C. Rab11a is essential for lamellar body biogenesis in the human epidermis. J. Invest. Dermatol. 2016, $136,1199-1209$ 